\title{
ATIVIDADE MICROBIANA DO SOLO E A INTERAÇÃO DE DIAZOTRÓFICOS ENDOFÍTICOS E FUNGOS MICORRÍZICOS ARBUSCULARES NA CULTURA DO TRIGO
}

VALÉRIA MARINO RODRIGUES SALA

Dissertação apresentada à Escola Superior de Agricultura "Luiz de Queiroz", Universidade de São Paulo, para obtenção do título de mestre em Agronomia, Área de Concentração: Microbiologia Agrícola.

\author{
PIRACICABA \\ Estado de São Paulo - Brasil \\ Fevereiro - 2002
}




\title{
ATIVIDADE MICROBIANA DO SOLO E A INTERAÇÃO DE DIAZOTRÓFICOS ENDOFÍTICOS E FUNGOS MICORRÍZICOS ARBUSCULARES NA CULTURA DO TRIGO
}

\author{
VALÉRIA MARINO RODRIGUES SALA \\ Engenheiro Agrônomo
}

Orientadora: $\mathrm{Dr}^{\mathrm{a}}$ ADRIANA PARADA DIAS DA SILVEIRA

\begin{abstract}
Dissertação apresentada à Escola Superior de Agricultura "Luiz de Queiroz", Universidade de São Paulo, para obtenção do título de mestre em Agronomia, Área de Concentração: Microbiologia Agrícola.
\end{abstract}

\author{
PIRACICABA \\ Estado de São Paulo - Brasil \\ Fevereiro - 2002
}




\section{Dados Internacionais de Catalogação na Publicaçăo (CIP) DIVISÃO DE BIBUIOTECA E DOCUMENTAÇĂO - ESALO/USP}

\section{Sala, Valerla Marino Rodrigues}

Atividade microblana do solo e a interaçào de diazotróficos endofiticos e fungos micorrizicos arbusculares na cultura do trigo / Valéria Marlno Rodrigues Sala. . . Piracicaba, 2002.

$124 \mathrm{p}$.

Dissertaço (mestrado) - E Escola Superior de Agricultura Luiz de Queiroz, 2002. Babliografla.

1. Fungos micomizicos 2. Manejo do solo 3. Microblologla đo solo 4. Relaçăo bactérla-fungo 5. Trigo L. Título

CDD 633.11 
Aos meus pais

$$
\begin{aligned}
& \text { Valquíria Ap. Marino } \\
& \qquad \begin{array}{l}
\text { Ivo Rodrigues } \\
\text { OFEREÇO }
\end{array}
\end{aligned}
$$

A meu marido

Andrea Sala

\section{DEDICO}




\section{AGRADECIMENTOS}

À Dra. Adriana Parada Dias da Silveira pela orientação, apoio, incentivo e principalmente pela amizade. Meu muito obrigada!

Ao Dr. José Guilherme e Dr. Paulo B. Gallo pelo ensaio de campo e pela contribuição dada a este trabalho.

À pesquisadora Dra. Maria Luiza Colognesi O. Lombardi por ter me introduzido na pesquisa científica na área de Microbiologia Agrícola.

À Dra. Sueli Santos Freitas pela participação em todas as etapas dessa pesquisa.

Ao Instituto Agronômico de Campinas pela oportunidade. Às funcionárias: Maria Leonilde, Tereza e Rosana, que tanto contribuíram para conclusão deste trabalho. Às amigas e colegas de laboratório, pelo apoio, amizade e pelo agradável convívio. Especialmente as amigas Deise Agnani, pelo companherismo durante todo o curso de Mestrado e a Vanessa P. Donzeli por dividir todas as dificuldades ao longo desse trabalho.

À FAPESP pela concessão da bolsa de estudo, e apoio financeiro prestado. 
À Escola Superior de Agricultura "Luiz de Queiroz" e ao curso de pósgraduação em Microbiologia Agrícola pela oportunidade de desenvolvimento desse trabalho.

Ao Dr Heitor Cantarella e ao Dr Luís Alberto Ambrosio pelos muitos esclarecimentos prestados.

À todos aqueles que, de uma maneira ou outra, prestaram o seu apoio e incentivo para realização desse trabalho. Meu muito obrigada! 


\section{SUMÁRIO}

Página

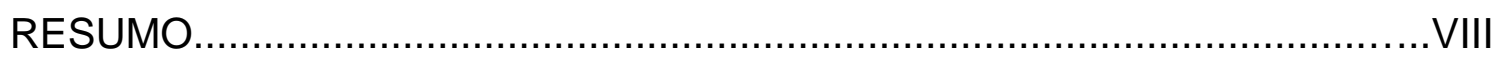

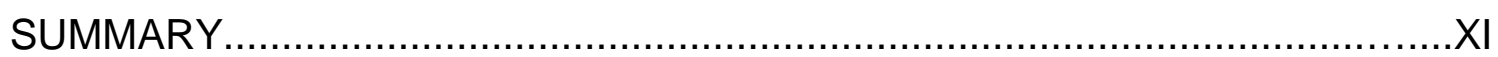

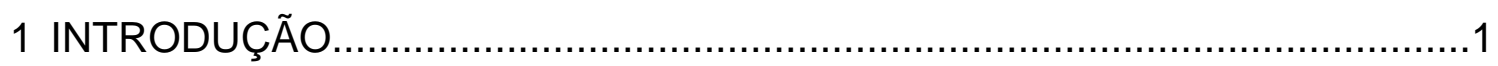

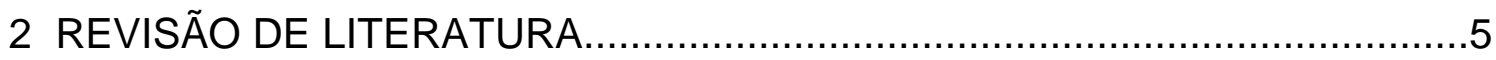

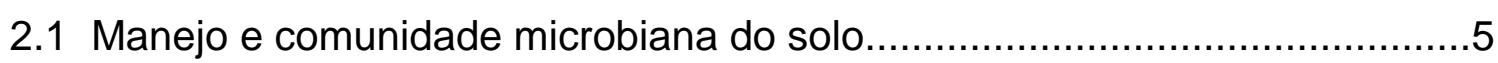

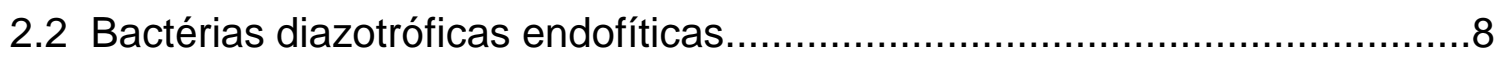

2.3 Interação de FMAs e bactérias diazotróficas endofíticas............................14

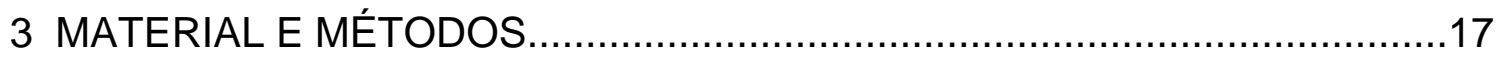

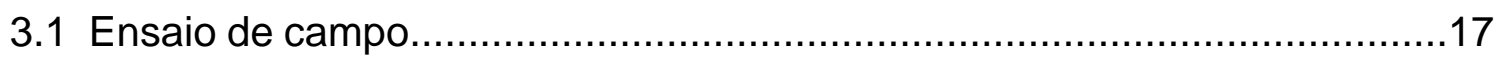

3.1.1 Produção de matéria seca da parte aérea...........................................19

3.1.2 Quantificação de bactérias diazotróficas endofíticas..............................19

3.1.3 Quantificação de microrganismos amonificadores.................................20

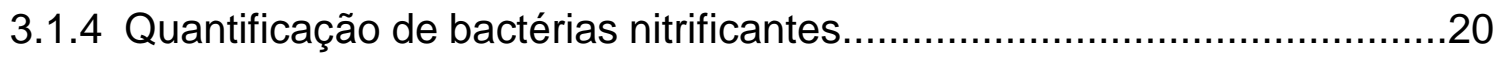

3.1.5 Análise do carbono da biomassa microbiana.....................................20

3.1.6 Análise do nitrogênio da biomassa microbiana....................................21

3.1.7 Análise da atividade microbiana por respirometria...............................21

3.1.8 Análise do teor de nitrogênio na parte aérea......................................21

3.1.9 Análise do teor de fósforo na parte aérea..........................................22

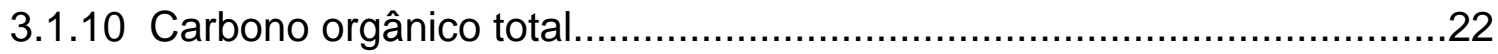

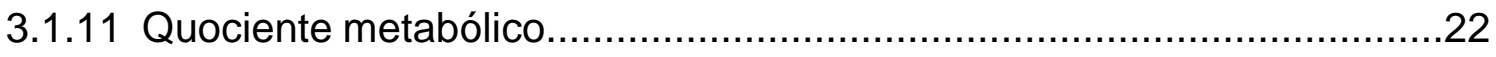

3.1.12 Relação carbono microbiano: cabono orgânico....................................22

3.1.13 Relação carbono microbiano: nitrogênio microbiano.............................22

3.1.14 Análise da colonização micorrízica....................................................22 


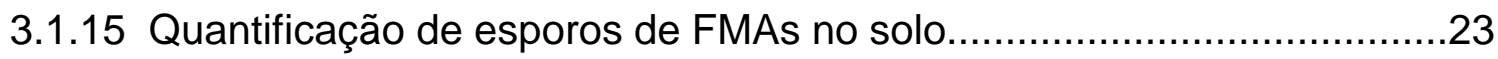

3.2 Isolamento e caracterização de bactérias diazotróficas endofíticas............23

3.3 Interação entre genótipos de trigo e diazotróficos endofíticos.....................24

3.4 Interação de FMAs e bactérias diazotróficas endofíticas...........................24

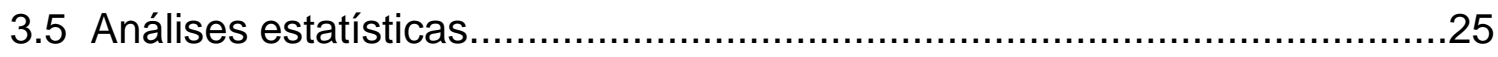

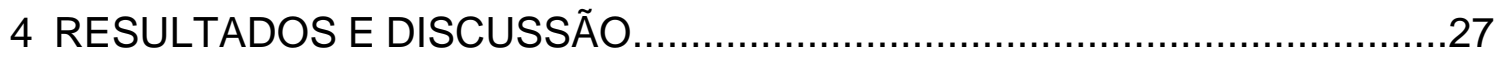

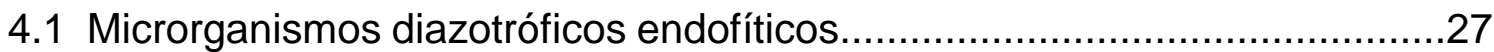

4.2 Análise da colonização micorrízica e quantificação de esporos de FMAs..42

4.3 Estudo da comunidade e da atividade microbianas do solo.......................46

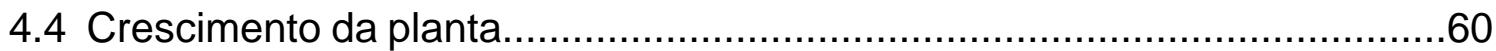

4.5 Interação de FMAs e bactérias diazotróficas endofíticas............................74

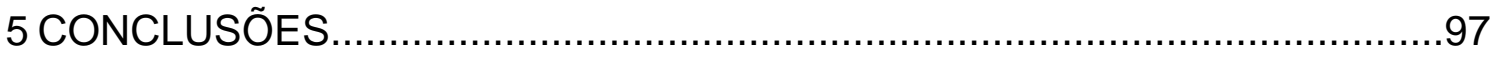

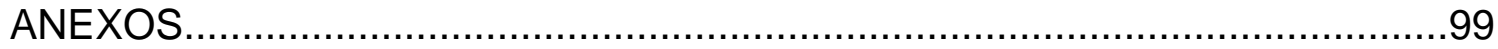

REFERÊNCIAS BIBLIOGRÁFICAS....................................................110 


\title{
ATIVIDADE MICROBIANA DO SOLO E A INTERAÇÃO DE DIAZOTRÓFICOS ENDOFÍTICOS E FUNGOS MICORRÍZICOS ARBUSCULARES NA CULTURA DO TRIGO
}

\author{
Autora : VALÉRIA MARINO RODRIGUES SALA \\ Orientadora : Dra. ADRIANA PARADA DIAS DA SILVEIRA
}

\section{RESUMO}

A pesquisa sobre bactérias diazotróficas associadas à cultura do trigo tem demonstrado a necessidade de associar bactérias eficientes a genótipos responsivos ao nitrogênio, os quais mais se beneficiariam dessa associação. Em um experimento com parcelas subdivididas instalado em condições de campo, em Mococa (SP), empregando os tratamentos: 3 doses de $\mathrm{N}(0,60 \mathrm{e}$ $120 \mathrm{~kg} \mathrm{ha}^{-1}$ ) $\times 3$ genótipos de trigo (IAC-24, ITD-19 e IAC-355), foi avaliada a ocorrência de microrganismos diazotróficos endofíticos em raízes desinfestadas superficialmente, utilizando-se 3 meios de cultivo distintos, NFb, semi-específico para Azospirillum spp, JNFb, semi-específico para Herbaspirillum spp., e LGI-P, semi-específico Gluconacetobacter diazotrophicus. O genótipo IAC-355 apresentou a menor quantidade de bactérias diazotróficas endofíticas. Além disso, para este genótipo, houve um ajuste linear ascendente da quantidade de bactérias diazotróficas com o aumento na quantidade de $\mathrm{N}$ adicionada, o que comprova a influência do genótipo da planta na associação com essas bactérias. Nenhuma bactéria pertencente aos gêneros Azospirillum ou Herbaspirillum foi isolada do genótipo IAC-355. Nas condições estudadas, não 
foi identificado nenhum isolado de Gluconacetobacter diazotrophicus nas raízes do trigo. Foram obtidos 8 isolados do gênero Azospirillum e 12 do gênero Herbaspirillum. Esses isolados foram testados "in vitro", no genótipo do qual foram originalmente isolados. Todos os isolados testados no genótipo ITD-19 causaram maior crescimento radicular que a testemunha e apenas 1 isolado de Herbaspirillum sp. propiciou aumento significativo do teor de $\mathrm{N}$ na parte aérea. A colonização micorrízica no genótipo IAC-355 foi maior que nos demais genótipos independente da dose de $\mathrm{N}$, comprovando a influência do genótipo na colonização. A colonização micorrízica se correlacionou com a massa da matéria seca, e com o teor e a quantidade acumulada de $\mathrm{P}$ e $\mathrm{N}$ na parte aérea, assim como com a produtividade. A atividade da biomassa microbiana foi alterada na ausência de $\mathrm{N}$, obtendo-se correlação entre $0 \mathrm{qCO}_{2}$ e a relação Cmic:Corg, indicando que na ausência de $\mathrm{N}$, houve perdas de $\mathrm{C}$ no solo cultivado com o genótipo IAC-24, enquanto que na presença do IAC-355, houve maior eficiência na utilização do $\mathrm{C}$ do solo pelos microrganismos. Na contagem de bactérias nitrificadoras obteve-se um ajuste linear ascendente em relação à quantidade de $\mathrm{N}$ adicionada, provavelmente devido à maior disponibilidade de substrato. A quantidade de microrganismos nitrificadores se correlacionou com a massa da matéria seca, e com o teor e a quantidade acumulada de $\mathrm{N}$ na parte aérea, assim como com a produtividade. A interação FMA-bactéria diazotrófica não propiciou benefícios para cultura do trigo. A interação FMAbactéria diazotrófica demonstrou ser bastante especifica. As plantas associadas a Glomus, quando em presença dos isolados bacterianos apresentaram maior crescimento, acúmulo e aproveitamento dos nutrientes. Confirmou-se que o fungo micorrízico realmente é um agente transmissor de bactérias diazotróficas endofíticas, sendo que Acaullospora causou maior colonização radicular. As plantas dos tratamentos em que somente a bactéria foi inoculada apresentaram o dobro da produção de matéria seca, da quantidade acumulada e do índice de eficiência de utilização de $\mathrm{N}$ e $\mathrm{P}$ na parte aérea em relação à testemunha. $\mathrm{A}$ especificidade da interação planta-bactéria diazotrófica associativa indica que é 
possível obter benefícios desta associação, explorando bactérias e cultivares locais. 


\title{
ROOT COLONIZATION OF WHEAT GENOTYPES BY DIAZOTROPHIC BACTERIA UNDER NITROGEN FERTILIZER ADDITION
}

\author{
Author : VALÉRIA MARINO RODRIGUES SALA \\ Adviser : Dra. ADRIANA PARADA DIAS DA SILVEIRA
}

\section{SUMMARY}

The research on diazotrophic bacteria associated to wheat has demonstrated the need to associate efficient bacteria to $\mathrm{N}$-responsive genotypes, which would be more benefited from this association. A field experiment was carried out in Mococa, state of São Paulo-Brazil, with 3 genotypes of wheat (IAC-24, ITD-19 and IAC-355) under 3 nitrogen doses $(0,60$ e $\left.120 \mathrm{~kg} \mathrm{ha}^{-1}\right)$. The occurrence of diazotrophic bacteria was evaluated in three media, namely, NFb semi-specific for Azospirillum spp., JNFb semi-specific for Herbaspirillum spp., and LGI-P semi-specific for Gluconacetobacter diazotrophicus, using surface-sterilized roots. Regardless the nitrogen dose, the population of diazotrophic bacteria established poorly in the genotype IAC-355, but the infection increased with the addition of nitrogen for the same genotype, proving the influence of the host genotype for its association with these bacteria. Azospirillum spp. or Herbaspirillum spp. could not be isolated from the surfacesterilized roots of IAC-355. In the field experiment $G$. diazotrophicus was not found in any of the wheat-genotype roots. It was obtained 12 Herbaspirillum spp. isolates and 8 Azospirillum spp isolates. These strains were tested under gnotobiotic conditions, using the genotype from which they had been originally 
isolated. Inoculated ITD-19 plants showed an increase in root length, even though, only one strain showed a significant increase on shoot $\mathrm{N}$ accumulation. In the genotype IAC-355 mycorrhizal colonization was higher, proving the influence of the plant genotype. Mycorrhizal colonization showed significant correlation to shoot dry matter, shoot $\mathrm{N}$ and shoot $\mathrm{P}$ concentration and accumulation, as well as to the grain yield. In the absence of added $\mathrm{N}$, the activity of microbial biomass was affected. The correlation between the $\mathrm{qCO}_{2}$ and biomass $\mathrm{C}$-to- $\mathrm{N}$ ratio, showed that in absence of $\mathrm{N}$, soil-C loss under IAC24 cultivation, but a greater efficiency in the use of the soil-C by the microorganisms under IAC-355 cultivation. The populations of nitrifying bacteria increased with $\mathrm{N}$ addition, probably due to the $\mathrm{N}$-rich substrate availability. The nitrifying bacteria showed significant correlation to shoot dry matter, shoot $\mathrm{N}$ concentration and accumulation, as well as to grain yield. There was no benefit from the AMF-diazotrophic bacteria co-inoculation on wheat plants. The specificity of AMF-diazotrophic bacteria interaction was demonstrated, it was confirmed that AMF indeed is a transmitting agent of endophytic diazotrophic bacteria, Acaullospora caused higher endophytic-bacteria root colonization. Plants inoculated with single strain doubled shoot dry matter, shoot $\mathrm{N}$ and $\mathrm{P}$ concentration and accumulation as compared to the control. Plant-bacteria interaction specificity demonstrates the possibility of getting benefits from this association by exploring both bacterial strains and plant genotypes from the same location. 


\section{INTRODUÇÃO}

Através da aplicação de tecnologias adequadas desenvolvidas e recomendadas pela pesquisa, como o emprego de cultivares adequados para cada região, adubações equilibradas, práticas de conservação do solo e controle fitossanitário permitiram um aumento da produtividade na cultura do trigo. No entanto, a demanda crescente pelas culturas alimentícias, torna necessária a continuidade da pesquisa em diversos aspectos.

As pesquisas com trigo tiveram início em 1919 no Brasil. Em 1974, considerava-se como média ideal $1500 \mathrm{~kg} / \mathrm{ha}$ em lavouras comerciais, uma vez que nos campos experimentais o rendimento médio obtido era de $2000 \mathrm{~kg} / \mathrm{ha}$. Hoje, estações experimentais na região Sul atingem mais de $5000 \mathrm{~kg} / \mathrm{ha}$ de rendimento médio e no Brasil Central chegam a superar $7000 \mathrm{~kg} / \mathrm{ha}$. No campo não são raros os produtores que colhem mais de $4000 \mathrm{~kg} / \mathrm{ha}$.

O nitrogênio constitui o macroelemento mais limitante na produtividade do trigo, pois determina o número de afilhos ou perfilhos, sendo essencial na fase de formação dos nós, no início do alongamento.

O trigo é a $2^{\mathrm{a}}$ cultura em grãos a nível mundial em produção. As maiores produtividades são obtidas nos países da União Européia, com produtividade média um pouco acima do Brasil segundo Bissoto ${ }^{1}$.

1 BISSOTO, V. Algumas considerações sobre a cultura do trigo. Reunião da Comissão SulBrasileira de Pesquisa de Trigo, 33., Passo Fundo: EMBRAPA, 2001. 
Possivelmente, com o lançamento de novas variedades desenvolvidas pela pesquisa, o Brasil ,em breve, atingirá a mesma produtividade. Mas devido a sua origem, uma região ecologicamente distinta, a cultura do trigo exige intensa pesquisa agronômica. Baggio ${ }^{2}$ afirma que os trigos brasileiros são conhecidos por apresentarem os melhores genes a nível mundial para tolerância à acidez do solo, resistência à ferrugem e outras doenças fúngicas.

O programa atual de melhoramento genético do IAC tem como alguns de seus objetivos principais o desenvolvimento de variedades responsivas à adubação nitrogenada, aspecto este intimamente relacionado com a pesquisa microbiológica.

Fertilizantes nitrogenados utilizados em plantas não leguminosas como 0 trigo constituem um dos mais altos custos da agricultura. Um elemento essencial para agricultura sustentável é o aproveitamento eficiente do $\mathrm{N}$ atmosférico (Graham \& Vance, 2000). Entre os sistemas biológicos capazes de aproveitar o nitrogênio diretamente da atmosfera, a simbiose rizóbio leguminosas tornou-se o sistema mais especializado, sendo responsável por $22 \%$ de todo nitrogênio incorporado ao ecossistema terrestre (Peoples et al.,1995). No Brasil, salienta-se a importância econômica e ecológica da fixação biológica do nitrogênio com o exemplo da soja, que dispensa totalmente a adubação nitrogenada sem causar perda de produtividade.

Um dos grandes interesses dos pesquisadores é a extensão desses processos biológicos para outras culturas, como gramíneas forrageiras e cereais especialmente os de grande importância sócio-econômica. Os cereais constituem a base alimentar mais importante para a população humana e ocupam em torno de $50 \%$ das terras cultivadas.

\footnotetext{
${ }^{2}$ BAGGIO, M.I. Genética e novas biotecnologias no melhoramento do trigo. Trigo 500 anos, Passo Fundo: EMBRAPA, 2000.
} 
Somente as culturas do trigo, milho e arroz consumiram $53 \%$ do total de fertilizantes utilizados no ano de 1991 (Peoples et al.,1995). Portanto, devido à extensa área ocupada pelos cereais, aproximadamente 5 vezes a das leguminosas, a fixação biológica associada a essas culturas torna-se de extrema importância, mesmo que apenas parte de suas necessidades de nitrogênio possa ser suprida.

Desde a descoberta de bactérias fixadoras de nitrogênio associadas à cana-de-açúcar por Döbereiner e seus colaboradores foi demonstrado o enorme potencial de bactérias endofíticas em aumentar a biomassa de gramíneas na ausência de fertilizantes nitrogenada. Novas bactérias fixadoras de nitrogênio vêm sendo isoladas e identificadas, incluindo espécies do gênero Azospirillum sp., Herbaspirillum sp. e Gluconacetobacter diazotroficus, graças à elucidação dos mecanismos de funcionamento da nitrogenase. Essas bactérias não possuem mecanismos de proteção ao oxigênio, demonstrando maior eficiência na utilização de fontes de carbono para fixação de $\mathrm{N}_{2}$, devido ao fato de serem endofíticas (Döbereiner et al., 1995).

Usando o paradigma da cana-de-açúcar como exemplo, seria imprescindível estimular a pesquisa com diazotróficos endofíticos na cultura do trigo, associando bactérias eficientes com genótipos responsivos, os quais mais se beneficiariam da associação com essas bactérias.

$O$ solo representa um ambiente heterogêneo que permite 0 desenvolvimento de grande diversidade de microrganismos, cujo equilíbrio é afetado por fatores bióticos e abióticos do ambiente. Ocorrem interações entre microrganismos do solo na rizosfera das plantas, mas que são pouco estudadas, como a dos fungos micorrízicos arbusculares e as bactérias diazotróficas.

Estudos de inoculação de FMAs com bactérias diazotróficas têm demonstrado que os fungos podem incrementar o desenvolvimento e os teores de nutrientes nas planta, aumentando a colonização pelas bactérias. E ainda, 
existem grandes evidências que FMAs são agentes transmissores de bactérias diazotróficas para plantas (Paula et al., 1992).

Para o desenvolvimento de práticas agronomicamente viáveis ao aproveitamento dessa fonte de $\mathrm{N}$, resta ainda, conhecer os mecanismos biológicos e bioquímicos envolvidos na associação, bem como identificar o principal microrganismo responsável pelo sistema fixador eficiente nas interações com diferentes genótipos de plantas.

Os objetivos do trabalho foram:

1 Avaliar o efeito da adubação nitrogenada e de diferentes genótipos de trigo na atividade e comunidade microbianas do solo.

2 Estudar os diazotróficos endofíticos associados ao trigo, verificando, inclusive a presença de Gluconacetobacter diazotroficus, até hoje não relatado nesta cultura.

3 Estudar a interação de diazotróficos endofíticos e FMAs, determinando a ação do fungo como agente de transmissão do endófito e os possíveis benefícios ao desenvolvimento da planta. 


\section{REVISÃO DE LITERATURA}

\subsection{Manejo e comunidade microbiana do solo.}

Os microrganismos do solo são responsáveis por inúmeras transformações físico-químicas de grande importância para produção agrícola. Os resíduos orgânicos incorporados aos solos sofrem ataque de microrganismos heterotróficos para dar atendimento a suas necessidades metabólicas na formação de seus constituintes protoplasmáticos. Durante o processo, normalmente ocorre liberação de $\mathrm{CO}_{2}$ para atmosfera e oscilações no balanço do nitrogênio do solo. Medições das variações das populações microbianas, da liberação de $\mathrm{CO}_{2}$ e das concentrações de amônio e nitrato servem como parâmetros indicadores da vida microbiana do solo (Nuernberg et al., 1984).

Material de origem orgânica ou mineral, bem como o tipo de exploração agrícola, podem ocasionar alterações quantitativas e qualitativas nas populações microbianas do solo e na sua atividade (Lupwayi et al., 1998).

Um solo saudável pode ser definido como uma contínua capacidade do solo em funcionar como um sistema vivo, dentro do ecossistema e do uso da terra, sustentando a produtividade biológica, promovendo a qualidade do ar e da água, e mantendo plantas, animais e seres humanos saudáveis (Doran \& Safley, 1997).

A avaliação do $\mathrm{C}$ da biomassa e C-mineralizável, segundo Franzluebbers et al (1995), foi $18 \%$ maior no sistema de rotação de culturas em relação à monocultura, provavelmente devido às raízes das culturas e dos resíduos acumulados, bem como ao curto período de exposição do solo. 
A disponibilidade do $\mathrm{N}$ inorgânico a partir de $\mathrm{N}$ orgânico (amonificação) é realizada por diversas populações de microrganismos, geralmente quantificada pela biomassa microbiana do solo. A biomassa microbiana pode contribuir significativamente para disponibilização do $\mathrm{N}$ do solo para as plantas, a quantidade de $\mathrm{N}$ inorgânico depende da taxa de decomposição da matéria orgânica do solo pela biomassa, da imobilização, da desnitrificação e da lixiviação (Lovell \& Hatch, 1998). O N da biomassa microbiana foi maior em solos que receberam adubo nitrogenado do que em solos que não foram adubados, e a imobilização desse $\mathrm{N}$ pela biomassa microbiana foi mais alta na primeira aplicação de $\mathrm{N}$, quando as plantas estão começando a crescer e a absorção de nutrientes é baixa (Blankenau et al.,2000).

O quociente microbiano (Carbono microbiano:Carbono orgânico), homogeneíza a quantificação da biomassa em solos que contem diferentes quantidades de carbono orgânico. Geralmente um solo com grande exploração agrícola, a relação Cmic:Corg será baixa. O quociente metabólico $\left(\mathrm{qCO}_{2}\right)$, também denominado de respiração específica, é maior em comunidades ecologicamente imaturas ou em comunidades que estejam sob alguma situação de stress, onde os microrganismos precisam gastar uma grande quantidade de energia por unidade de biomassa. O quociente metabólico deve ser interpretado com cuidado, uma vez que uma baixa taxa de respiração específica pode indicar que parte da microflora é pouco ativa devido a deficiência de substrato, ou devido à proteção física em agregados (Sparling, 1997).

$\mathrm{Na}$ relação solo-planta, a aquisição de nutrientes pode ser diretamente afetada por uma microflora ou rizosfera não infectada por microrganismos. Dependendo da composição ou da densidade dessas populações, a exudação das raízes pode ser aumentada várias vezes, assim como a concentração de ácidos orgânicos e quelatos devido ao metabolismo microbiano. Os microrganismos rizosféricos podem aumentar ou diminuir o crescimento das raízes e a formação dos pêlos radiculares, e a disponibilidade espacial de nutrientes (Marschener, 1998). 
Lupwayi et al. (1998) demonstraram que o cultivo convencional reduziu significativamente a diversidade de bactérias na cultura do trigo, aumentando a predominância de poucos grupos de microrganismos e reduzindo a fertilidade do solo. Esses efeitos foram mais pronunciados no segundo ano de cultivo, sendo a diversidade mais influenciada em profundidade. Esses resultados indicam que a rotação de culturas permite a diversidade das comunidades microbianas no solo e podem afetar a sustentabilidade dos sistemas agrícolas.

A cobertura vegetal permanente propicia proteção contínua da superfície, mantendo a umidade e diminuindo a amplitude térmica no solo, e ainda, adicionando grande quantidade de nutrientes. O estímulo das populações de bactérias e fungos pode estar relacionado com as diferentes composições dos resíduos provenientes das rotações de cultura, alternância de períodos de acúmulo de resíduos orgânicos na superfície do solo e posterior revolvimento, com a incorporação desses resíduos (Silva \& Vidor, 1984).

De acordo com Cattelan \& Vidor (1990), a profundidade exerce grande efeito sobre os microrganismos, sendo a biomassa e a liberação de $\mathrm{CO}_{2}$ sensivelmente menores em profundidade. A biomassa bacteriana possui estreita relação com a atividade respiratória, pois geralmente, os fatores que estimulam a atividade microbiana também favorecem a formação de sua biomassa.

As gramíneas, apesar das excreções com grande relação C:N, possuem um sistema radicular mais denso que as leguminosas de renovação mais intensa, o que torna seu efeito rizosférico total maior que o propiciado pelas leguminosas (Silva \& Vidor, 1984).

Além da relação C:N e de outras características inerentes ao resíduo, a atividade microbiana depende de condições ambientais, como pH, aeração e cobertura vegetal, e dos diferentes sistemas de produção utilizados. O conhecimento das influências dessas variáveis sobre a comunidade e a atividade microbianas pode auxiliar na recomendação de práticas culturais que minimizem a competição por nutrientes (imobilização) entre os microrganismos 
e as plantas cultivadas, ou que aumentem a eficiência do uso de nutrientes pelas plantas, resultante da mineralização da matéria orgânica do solo.

\subsection{Bactérias diazotróficas endofíticas}

A partir das observações pioneiras de Döbereiner \& Day (1976) de que o uso de meios semi-sólidos era a condição ideal para o crescimento de diazotróficos dependentes da fixação biológica do nitrogênio da atmosfera, esse método tem sido empregado extensivamente no isolamento e caracterização de microrganismos fixadores associados a diferentes plantas e condições de clima e solo (Döbereiner et al.,1976). Observou-se que tais diazotróficos ocupam preferencialmente, sítios onde a concentração de $\mathrm{O}_{2}$ é limitada. Esta descoberta revolucionou e ampliou as pesquisas sobre todos os aspectos da fixação biológica do nitrogênio nas associações entre diazotróficos e não leguminosas, denominadas comumente de simbiose associativa ou fixação de $\mathrm{N}_{2}$ associativa (Baldani et al., 1997).

As bactérias diazotróficas de plantas não leguminosas podem ser agrupadas em três categorias: organismos rizosféricos, endofíticos facultativos e endofíticos obrigatórios (Baldani et al., 1997). Na primeira categoria estão todas as espécies que colonizam as raízes superficialmente. Os microrganismos endofíticos facultativos são aqueles capazes de colonizar raízes interna e externamente e, o terceiro grupo, tido como de maior importância, os que colonizam o interior de raízes e também a parte aérea das plantas não leguminosas.

Estudos recentes relatam Azospirillum sp., um endofítico facultativo, como sendo o grupo mais promissor associado a gramíneas e não leguminosas, devido sua capacidade de colonizar todo o interior da planta, localizando-se dentro de habitats protegidos do oxigênio (Baldani et al., 1997).

As bactérias do gênero Azospirillum foram identificadas inicialmente como Spirillum lipoferum por Dobereiner \& Day (1976), isoladas a partir de raízes de Digitaria. Posteriormente, foi proposto o gênero Azospirillum com 
duas espécies: $A$. lipoferum e $A$. brasiliense com base em diferenças morfológicas, fisiológicas e também através de homologia de DNA entre os isolados analisados. Atualmente, outras espécies foram descritas como $A$. amazonense (Magalhães et al.,1983), isolada de gramíneas forrageiras e pupunha nativa da região Amazônica, A. halopraeferans (Reinhold et al.,1987), isolada de gramíneas do Paquistão e A. irakense (Khammas et al.,1989) isolada de plantas de arroz no Iraque.

As espécies de maior relevância como fixadoras de nitrogênio isoladas de cereais são $A$. lipoferum e $A$. brasiliense (Baldani et al.,1997). Entre todas as 5 espécies de Azospirillum conhecidas, $A$. brasiliense constitui a mais caracterizada fisiologicamente e através de métodos moleculares. Essas bactérias se diferenciam na habilidade de crescer em glucose, entretanto, somente $A$. lipoferum é capaz de utilizar glucose como única fonte de carbono (Dobereiner et al.,1995).

Azospirillum spp. pode ser caracterizado como bactéria gram negativa, tipo bastonete, bastante móvel, com 0,8 a $1 \mu \mathrm{m}$ de diâmetro, 2 a $4 \mu \mathrm{m}$ de comprimento, com grânulos intracelulares de poli-hidroxibutirato. São aeróbios típicos, quando supridos com fonte de nitrogênio combinado, e microaerofílicos, quando crescem dependentes da fixação de $\mathrm{N}_{2}$. Em meio semi-sólido formam uma película delgada em forma de véu, abaixo da superfície do meio, onde a concentração de oxigênio permite a fixação do nitrogênio para iniciar seu crescimento, movendo-se em direção à superfície, quando as células atingem número suficientemente elevado, para escoar o $\mathrm{O}_{2}$ excessivo que se acumula em volta das mesmas, ativando assim a nitrogenase (Dobereiner et al.,1995).

Algumas espécies do gênero Azospirillum possuem mecanismos específicos de interação com as raízes e são aptas a colonizar todo o interior das mesmas, enquanto outras, apenas colonizam a camada de mucilagem ou células do córtex danificadas das raízes. Com a esterilização superficial das raízes foi demonstrado que realmente certas espécies de Azospirrilum spp. colonizam o interior das raízes do trigo (Steenhoudt \& Vanderleyden, 2000). 
A localização do diazotrófico não revela muito sobre a simbiose. Entretanto, se altas concentrações de bactérias são encontradas associadas ou no interior das plantas, isso não significa que estão expressando nitrogenase. A expressão dos genes nif e/ou proteínas da nitrogenase, e a atividade de redução do acetileno já foram demonstradas, mas ainda não ficou estabelecido que os produtos da fixação são transferidos para o hospedeiro. A morte e subseqüente mineralização do diazotrófico pode liberar quantidades significativas do $\mathrm{N}$ fixado, mas esse processo é ineficiente, e provavelmente tardio, quando comparado a imediata liberação de produtos da fixação do $\mathrm{N}_{2}$ por bactérias vivas como ocorre nos nódulos de plantas leguminosas. Além disso, nenhum diazotrófico endofítico associado à cana-de-açúcar ou a outras gramíneas foi encontrado dentro de células vivas do hospedeiro (James, 2000). Além do mais, pode ser somente uma extensão da relação solo-população bacteriana rizosférica, a qual possui vantagens de um habitat protegido que 0 interior da planta pode propiciar.

Outra bactéria endofítica de grande importância pertence ao gênero Herbaspirillum, fazendo parte do grupo das endofíticas obrigatórias. Herbaspirillum spp. são bactérias gram negativas, em formato de bastonetes curvos, fixadoras de nitrogênio em condições microaerófilas. São conhecidas duas espécies do gênero capazes de fixar $\mathrm{N}_{2}: H$. seropedicae e $H$. rubrisubalbicans muito semelhantes, e que podem ser diferenciadas através do uso de algumas fontes de carbono. $H$. seropedicae é capaz de usar $\mathrm{N}$ acetilglucosamina como única fonte de $\mathrm{C}$, em condições de fixação de $\mathrm{N}$ com meio JNFb semi-sólido sem ácido málico, e $H$. rubrisulbalbicans utiliza mesoeritrol somente em meio mineral (Olivares et al., 1997).

$H$. seropedicae possui menor especificidade hospedeira quando comparada com $G$. diazotrophicus, tendo sido isolada de muitas gramíneas, como milho, sorgo, arroz, cana-de-açúcar e gramíneas forrageiras. Também tem sido isolada de outras plantas não leguminosas, incluindo palmeiras. Pode infectar raízes, colmos e folhas de graníferas mais não é encontrada em folhas 
de cana-de-açúcar. Sua disseminação natural ainda não está bem esclarecida, mas parece ser disseminada principalmente por sementes, e ocasionalmente pode ser isolada de sementes de cereais (Baldani et al.,1997).

Outra espécie do gênero, $H$. rubrisubalbicans, antiga Pseudomonas rubrisubalbicans, foi descrita como agente causal da estria mosqueada da cana-de-açúcar, e mais tarde encontrada em variedades de sorgo em Queensland causando a doença da estria vermelha. Entretanto, não ocorreu sintomas da doença em variedades de sorgo brasileiras e nos campos de canade-açúcar, sendo que todos os cultivares testados se mostraram resistentes após a inoculação artificial (Olivares et al.,1997). Inicialmente pensou-se que $H$. rubrisubalbicans era restrita a variedades de cana-de-açúcar, sendo recentemente isolada de plantas de arroz e palmeiras.

Como outros endofíticos, Herbaspirillum spp. não sobrevive no solo, sendo menos afetado em solos esterilizados, indicando que os fatores bióticos interferem na sua sobrevivência, embora esta seja maior que a observada em G. diazotrophicus (Baldani et al.,1997).

Mais recentemente, uma nova espécie de bactéria fixadora de nitrogênio, Acetobacter diazotrophicus foi descoberta, ocorrendo em grande número nas raízes e na parte aérea de plantas de cana-de-açúcar (Cavalcante \& Dobereiner,1988). Esse novo diazotrófico foi originalmente isolado de caldo de cana semi-sólido ao qual foram inoculadas diluições de raízes e folhas de cana-de-açúcar, observando-se atividade de redução de acetileno nas diluições acima de $10^{-6}$ a $10^{-7}$ (peso matéria fresca). Um meio de cultura mais específico, LGIP, foi então idealizado (Reis et al.,1994).

Gluconacetobacter diazotrophicus, anteriormente denominada Acetobacter diazotrophicus, é uma bactéria gram negativa, medindo de 0,7 a 0,8 x 2 a $4 \mu \mathrm{m}$, aeróbia, não demonstrando movimento espiralado. Em meio semi-sólido livre de $\mathrm{N}$ com $100 \mathrm{~g} \mathrm{~L}^{-1}$ de sacarose, mas sem caldo de cana há a formação de uma película, que se torna densa após 7 a 10 dias. O melhor crescimento ocorre em alta concentração de sacarose ou glucose $\left(100 \mathrm{~g} \mathrm{~L}^{-1}\right) \mathrm{e}$ 
uma alta produção de ácido resulta em pH final abaixo de 3.0. O crescimento e a fixação de $\mathrm{N}_{2}$ continua nesse $\mathrm{pH}$ por vários dias. Etanol é também usado como fonte de carbono e oxidado a $\mathrm{CO}_{2}$ e $\mathrm{H}_{2} \mathrm{O}$. Em meio batata-agar com $100 \mathrm{gL}^{-1}$ de sacarose são formadas colônias marrom escuras, e em meio sólido, pobre em nitrogênio mineral $\left(0.02 \mathrm{gL}^{-1}\right.$ de extrato de levedura) e com $100 \mathrm{gL}^{-1}$ de sucrose e azul de bromotimol, as colônias são alaranjadas. A bactéria não possui nitrato redutase e a fixação de $\mathrm{N}_{2}$ não é afetada mesmo com altos níveis de $\mathrm{NO}_{3}{ }^{-}(25 \mathrm{mM})$ e também, a presença de $\mathrm{NH}_{4}{ }^{+}$causa somente inibição parcial da nitrogenase (Boddey et al.,1991).

Um aspecto importante é que G. diazotrophicus cultivado em $10 \%$ de sacarose apresenta uma concentração de $\mathrm{O}_{2}$ dissolvida ideal para o equilíbrio da redução de acetileno com $0,2 \mathrm{KPa}$ de $\mathrm{O}_{2}$ na atmosfera, mas continua fixando $\mathrm{N}_{2}$ acima de $4,0 \mathrm{KPa}$, demonstrando uma maior tolerância ao $\mathrm{O}_{2}$ que Azospirillum spp (Boddey et al.,1995). Outra característica única dessa bactéria é de excretar parte do nitrogênio fixado no meio de cultura como demonstrado por Cojho et al.(1993). Mais recentemente foi determinado que amônio era produzido e excretado por G.diazotrophicus, quando em condições não ideais à fixação de nitrogênio (Cruz et al.,1995).

G. diazotrophicus é a única espécie do gênero capaz de fixar $N_{2}$. Sua ocorrência é bastante restrita, estando principalmente associada a plantas ricas em açúcar, como a cana-de-açúcar, batata doce e capim camerrom, as quais se propagam vegetativamente (Dobereiner et al.,1995). Recentemente foi constatado por Jimenes-Salgado (1997) a presença de G. diazotrophicus em plantas de café, levando a acreditar que muitas outras culturas devem ser pesquisadas quanto à presença do endófito. Usando o paradigma da cana-deaçúcar como exemplo, pesquisadores estão trabalhando na descoberta e análise de diazotróficos endofíticos na cultura do trigo, o qual inclui a procura do genótipo de trigo que mais se beneficiaria na associação com essas bactérias.

De acordo com Bashand \& Levanony (1990) aumentos moderados, em torno de $20 \%$, atribuídos à inoculação com diazotróficos endofíticos, seriam 
considerados comercialmente significativos na agricultura moderna, desde que consistentes. Uma das variáveis que contribuem para complexidade das respostas de produção à inoculação é o genótipo da planta, que freqüentemente mostra respostas diferenciais, além do efeito da estirpe inoculada. O efeito do genótipo da planta sobre a fixação associativa tem sido amplamente demonstrado em cereais (Holl,1983).

Em muitos casos, a ausência de resposta à inoculação tem sido atribuída ao uso de linhagens inadequadas (Dobereiner \& Duque,1980), pois parece haver certa compatibilidade entre a bactéria e a planta hospedeira.

Baldani \& Dobereiner (1980) testaram diferentes estirpes em trigo com origens diversas e concluíram que estirpes isoladas da própria espécie vegetal (homólogas) tendem a ser mais eficientes do que as isoladas de plantas de outras espécies. O trabalho de Baldani et al. (1983), também apresenta resposta positiva de plantas de trigo com bactérias isoladas da própria cultura e ausência de resposta, quando utilizou-se ertirpes isoladas de milho.

Didonet et al. (1996) e Rodrigues et al. (2000) avaliaram a biomassa do colmo e da folha em plantas de trigo colonizadas por Azospirillum spp. e observaram que houve maior absorção de $\mathrm{N}$ na fase pós-antese, período em que a maior disponibilidade de $\mathrm{N}$ não promoveu aumento na produção de grãos.

Foram executados cerca de 100 ensaios sobre a inoculação de Azospirillum spp. em cereais. A inoculação desta bactéria tem se mostrado eficiente em aumentar a atividade da nitrogenase e propiciar ganhos, principalmente no acúmulo de matéria seca, produção de grãos, concentração de nitrogênio e outras características agronômicas na maioria dos estudos, mas também sem efeitos ou com efeitos prejudiciais em outros. Em geral, o efeito da inoculação de Azospirillum spp. sobre a produção situa-se em torno de 10 a $30 \%$, e em alguns casos valores mais elevados de 50 a $250 \%$ tem sido mencionados sobre o controle não inoculado (Boddey \& Döbereiner, 1988). 
Em Israel, onde os solos possuem baixa ou nenhuma comunidade nativa de Azospirillum spp., as respostas à inoculação são mais consistentes e a recomendação de inoculação já apresenta aspectos comerciais (Okon, 1985).

Mesmo nos casos de respostas positivas, nem sempre o efeito pode ser atribuído à fixação de $\mathrm{N}_{2}$. Algumas linhagens de Azospirillum spp. produzem hormônios de crescimento em cultura pura (Bottini et al., 1989) e sabe-se que essas substâncias alteram a morfologia do sistema radicular, aumentam a densidade de raízes e interferem no crescimento das plantas.

Tratando-se de bactérias diazotróficas, acreditava-se que a fixação de $\mathrm{N}_{2}$ na ecto, endorizosfera ou dentro de raízes e a liberação de parte do nitrogênio fixado para a planta fosse o principal modo de ação de Azospirillum spp, sobre o hospedeiro. Entretanto, os efeitos estimuladores de crescimento de planta ocorrem em vários estudos, onde se observam respostas positivas à inoculação dessas bactérias (Boddey \& Döbereiner, 1988).

\subsection{Interação de fungos micorrízicos arbusculares e bactérias diazotróficas endofíticas.}

Fungos micorrízicos arbusculares (FMAs) são reconhecidos pelo benefício considerável que promovem à planta hospedeira, especialmente onde a disponibilidade de nutrientes é baixa. Os FMAs podem ocasionar aumento no crescimento da planta, devido à melhoria proporcionada ao seu estado nutricional, particularmente em solos de baixa fertilidade, substituindo em parte os fertilizantes fosfatados e aumentando a eficiência das adubações (Goh et al.,1997). Existem vários relatos sobre como FMAs aumentam a absorção de vários nutrientes, especialmente os pouco móveis no solo, como $\mathrm{P}, \mathrm{Zn}$ e $\mathrm{Cu}$. As pesquisas enfatizam a necessidade de se obter variedades mais eficientes na utilização de nutrientes e que sejam responsivas à micorrização, garantindo a maior produção possível (Manske et al.,1995).

A herdabilidade de plantas responsivas a fungos micorrízicos tem sido demonstrada por diversos trabalhos que descrevem diferenças de respostas 
entre cultivares de várias plantas, incluindo trigo (Azcon \& Ocamp,1981). No estudo da herdabilidade da dependência micorrízica foi observado que todos os cultivares de trigo testados e seus ancestrais eram colonizados por FMAs, apesar de variarem significativamente na resposta à simbiose (Hetrick et al., 1993). Desta forma, a transmissão de bactérias diazotróficas para plantas pode estar relacionada à presença de FMAs, como demonstrado por Paula et al. (1991). A bactéria está presente em esporos de fungos micorrízicos, mas ainda se desconhece sua função. Paula et al. (1991) detectaram a presença de várias bactérias diazotróficas em esporos de Glomus clarum. Inoculação de esporos esterilizados de FMAs e $A$. diazotrophicus ou uma mistura de diazotróficos incluindo G. diazotrophicus, Klebsiella e outros, foi avaliada em plantas de sorgo sacarino, batata doce e cana-de-açúcar. Com a inoculação de ambos os microrganismos, o número de diazotróficos dentro das raízes esterilizadas superficialmente de batata doce e cana-de-açúcar foi significativamente maior quando comparado aos tratamentos em que não houve inoculação ou somente inoculação de diazotróficos.

No processo de penetração das hifas infectivas, pode ocorrer maior exudação de nutrientes pela planta, acelerando o crescimento de bactérias diazotróficas (Paula et al, 1991). O efeito benéfico propiciado pela interação também pode ser devido ao incremento na absorção de $P$ pelas plantas micorrizadas, propiciando melhores condições para o estabelecimento da associação com diazotróficos, o que representa alto custo energético (Pacovsky, 1989).

Isopi et al. (1995) avaliaram o efeito de FMAs e G. diazotrophicus em plantas de sorgo. As bactérias diminuíram a porcentagem de colonização de fungos nas raízes, mas os fungos aumentaram a infecção por diazotróficos nas raízes, colmos e folhas. $\mathrm{O}$ teor de $\mathrm{N}$ também aumentou nas plantas, especialmente na presença de ambos microrganismos, os quais também interferiram no tamanho das raízes, que se tornaram mais compridas e ramificadas. 
Pacovsky (1989) estudou o efeito da inoculação de Glomus fasciculatum e Azospirillum brasilense na cultura do sorgo. Os tratamentos controle foram suplementados com $\mathrm{N}$ e P a fim de compensar os nutrientes propiciados pela inoculação do diazotrófico ou do fungo. Os tratamentos que continham o fungo receberam uma solução sem $\mathrm{P}$, os com diazotrófico receberam uma solução livre de $\mathrm{N}$ e, naqueles com ambos microrganismos não foram adicionados $\mathrm{P} e$ N. As plantas colonizadas por Glomus fasciculatum continham um teor menor de $\mathrm{P}, \mathrm{Mn}$ e sucrose e maior de $\mathrm{Cu}, \mathrm{Zn}$ e prolina que as plantas colonizadas por Azospirillum spp. As raízes colonizadas por FMAs mostraram ácidos graxos não encontrados nos demais tratamentos. As plantas colonizadas pelo diazotrófico tiveram seu requerimento nutricional, composição de membrana e níveis metabólicos alterados, demonstrando que a colonização por endofíticos influencia a fisiologia da planta hospedeira. Pacosky (1989) também demonstrou que em plantas de milho a fisiologia era alterada tanto pela inoculação de FMA como de Azospirillum sp.

Bactérias diazotróficas endofíticas presentes dentro de esporos de FMAs permitem a penetração e colonização de raízes de plantas, passando para parte aérea (Paula et al.,1991). A inoculação de FMAs parece ser a condição essencial para colonização de todas as partes da planta por bactérias endofíticas fixadoras de $\mathrm{N}_{2}$, principalmente pelo fato destas bactérias não poderem ser isoladas do solo. Na seleção do diazotrófico e FMA mais eficientes, um dos aspectos relevantes a ser considerado, diz respeito ao genótipo da planta, que deve ser compatível a ambos microrganismos, o que levaria ao sucesso da inoculação no campo. 


\section{MATERIAL E MÉTODOS}

\subsection{Ensaio de Campo}

O ensaio de campo foi instalado na Estação Experimental de Mococa do Instituto Agronômico de Campinas, em Mococa-SP (Zona H), em um solo podzólico vermelho-escuro distrófico, após a cultura do milho, com irrigação por aspersão.

Este ensaio foi instalado pelo Centro de Graníferas do Instituto Agronômico de Campinas, sendo parte integrante do projeto "Resposta de genótipos de trigo ao redutor de crescimento associado às doses de nitrogênio para o Estado de São Paulo e estados limítrofes".

As adubações de $\mathrm{P}, \mathrm{K}$ e micronutrientes foram feitas baseadas na análise de solo do experimento (tabela 1) e na tabela de recomendação de adubação para a cultura do trigo irrigado para o Estado de São Paulo (Raij et al., 1997). A adubação com fósforo, potássio, zinco e boro para todas as subparcelas foi feita na forma de superfosfato simples, cloreto de potássio, sulfato de zinco e bórax, respectivamente. 
Tabela 1. Análise da fertilidade do solo do experimento de campo, Mococa-SP.

\begin{tabular}{lccc}
\hline & \multicolumn{3}{c}{ Profundidade, cm } \\
& $0-20$ & $20-40$ & $40-60$ \\
\hline $\mathrm{NH}_{4}, \mathrm{mg} \mathrm{kg}^{-1}$ & 2,2 & 2,6 & 1,1 \\
$\mathrm{NO}_{3}, \mathrm{mg} \mathrm{kg}^{-1}$ & 6,8 & 1,7 & 1,7 \\
$\mathrm{MO}, \mathrm{g} \mathrm{dm}^{3}$ & 21 & 13 & 8 \\
$\mathrm{PH}, \mathrm{CaCl}_{2}$ & 5,7 & 5,5 & 5,2 \\
$\mathrm{P}, \mathrm{mg} \mathrm{dm}^{3}$ & 44 & 3 & 1 \\
$\mathrm{Ca}, \mathrm{mmolc} \mathrm{dm}^{3}$ & 37 & 15 & 10 \\
$\mathrm{Mg}, \mathrm{mmolc} \mathrm{dm}^{3}$ & 11 & 6 & 5 \\
$\mathrm{H}+\mathrm{Al}, \mathrm{mmolc} \mathrm{dm}^{3}$ & 20 & 22 & 22 \\
$\mathrm{~S} . \mathrm{B} ., \mathrm{mmolc} \mathrm{dm}^{3}$ & 51,3 & 22 & 15,6 \\
$\mathrm{C} . \mathrm{T} . \mathrm{C}, \mathrm{mmolc}^{3}$ & 71 & 44 & 38 \\
dm & & & \\
V\% & & 49 & 41 \\
B, mg dm & & & \\
$\mathrm{Cu}, \mathrm{mg} \mathrm{dm}^{3}$ & 0,13 & & \\
$\mathrm{Fe}, \mathrm{mg} \mathrm{dm}^{3}$ & 1 & & \\
$\mathrm{Mn}, \mathrm{mg} \mathrm{dm}^{3}$ & 19 & \\
$\mathrm{Zn}, \mathrm{mg} \mathrm{dm}^{3}$ & 2,4 & \\
\hline
\end{tabular}

O delineamento experimental utilizado foi em faixas com blocos ao acaso e parcelas subdivididas, com 3 repetições. As parcelas $\left(1,2 \times 24,0 \mathrm{~m}=28,8 \mathrm{~m}^{2}\right)$ analisadas foram constituídas de 3 doses de nitrogênio, sem adubação nitrogenada, com $60 \mathrm{~kg} \mathrm{~N}^{-1}$ e $120 \mathrm{~kg} \mathrm{ha}^{-1}$ de $\mathrm{N}$, na forma de uréia. Nas subparcelas foram instalados três genótipos de trigo: IAC-24, Triticum aestivum hard L., eficiente e não responsivo à adubação nitrogenada, ITD-19, Triticum durum L., ineficiente e responsivo, e IAC-355, Triticum aestivum hard L., eficiente e responsivo, sendo três materiais distintos quanto a sua genealogia: IAC-24= IAS51/4/SON64/Y50E//GTO/3/2*CIANO 
IAC-355= PFAU/SERI//BOW"S"

ITD-19= GYS"S"/3/STN"S"//HUI"S"/SOMO"S"

As amostras para as análises microbiológicas foram obtidas 40 dias após a semeadura, fase de perfilhamento das plantas. Em cada parcela experimental colheu-se $60 \mathrm{~cm}$ lineares de planta, de uma das linhas centrais, coletando-se a parte aérea das plantas, a raiz e o solo, que foram devidamente acondicionados em sacos plásticos e etiquetados. No laboratório, as raízes foram separadas do solo, sendo parte delas acondicionadas em álcool 50\% para posterior determinação da colonização micorrízica e parte utilizada para quantificação e isolamento de microrganismos diazotróficos endofíticos.

As sequintes variáveis foram analisadas:

\subsubsection{Produção de matéria seca da parte aérea}

A parte aérea das plantas obtidas em $60 \mathrm{~cm}$ lineares na linha de plantio foi seca em estufa a $60^{\circ} \mathrm{C}$, com circulação de ar para posterior pesagem.

\subsubsection{Quantificação de bactérias endofíticas diazotróficas}

Para a quantificação de bactérias endofíticas diazotróficas foram tomados $10 \mathrm{~g}$ de raízes de cada parcela e submetidas à desinfecção superficial com solução de cloramina-T a 1\% por 15 minutos. Seguiu-se a lavagem com água esterilizada por 5 minutos e a transferência para uma solução tampão fosfato $0,05 \mathrm{M}(\mathrm{pH} \mathrm{7,0)}$, lavando-se posteriormente com água esterelizada.

As raízes desinfestadas foram trituradas, com solução de sacarose a $4 \%$ por dois minutos. A seguir, foram feitas diluições seriadas das amostras em solução de sacarose, de $10^{-2}$ a $10^{-7}$.

A contagem foi feita em meio semi-sólido pela inoculação de $0,1 \mathrm{ml}$ de cada diluição no centro do meio semi-sólido sem nitrogênio semi-específico para o diazotrófico desejado, ou seja, NFb, JNFb e LGI-P para Azospirillum sp., Herbaspirillum sp. e G. diazotrophicus respectivamente (Dobereiner et al.,1995). Foram utilizados 5 frascos por diluição, avaliando-se através do método do 
número mais provável, baseado na presença ou ausência de película formada no meio semi-sólido após 7 dias de incubação a $28^{\circ} \mathrm{C}$.

\subsubsection{Quantificação de microrganismos amonificadores}

Foi utilizado o método do NMP, usando-ses as diluições de $10^{-4}$ a $10^{-10}$ em meio específico para amonificadores (Sarathchandra,1978). Após incubação por 5 dias, procedeu-se à avaliação da presença de $\mathrm{NH}_{4}{ }^{+}$, sendo que os tubos com crescimento positivo demonstraram mudança de cor do meio de cultura, de laranja para rosa, devido a mudança de $\mathrm{pH}$.

\subsubsection{Quantificação de bactérias nitrificantes}

Procedeu-se à diluição do solo de $10^{-1}$ a $10^{-5}$ e transferiu-se $1 \mathrm{ml}$ de cada diluição para o meio proposto por Pramer \& Schimidt (1964) que quantifica as bactérias nitrificantes pelo método do número mais provável. Foram utilizados 5 tubos por diluição, incubando-se por um período de 10 semanas. Transcorrido esse tempo, os tubos foram analisados quanto à presença de $\mathrm{NO}_{2}{ }^{-}$e $\mathrm{NO}_{3}{ }^{-}$, com o reagente de Griess. Para análise de $\mathrm{NO}_{2}{ }^{-}$, foram colocadas em uma placa de toque (placa de porcelana com escavações), 6 gotas do reagente de Griess juntamente com $0,5 \mathrm{ml}$ do meio de cultura. $O$ aparecimento de coloração avermelhada indicou a presença de $\mathrm{NO}_{2}{ }^{-}$. A presença de $\mathrm{NO}_{3}{ }^{-}$foi evidenciada pela reação com pó de zinco, aparecendo uma coloração rosa, nos tubos negativos para $\mathrm{NO}_{2}$.

\subsubsection{Análise do Carbono da biomassa microbiana}

Foi utilizado o método da fumigação-extração que analisa a biomassa microbiana extraível em solução aquosa de $\mathrm{K}_{2} \mathrm{SO}_{4}$ a $0,5 \mathrm{M}$. A fumigação de $20 \mathrm{~g}$ de solo foi feita com clorofórmio, por 5 dias a $28^{\circ} \mathrm{C}$ em ambiente escuro, que além de matar, lisa as células microbianas liberando o citoplasma para o solo, permitindo a extração do C do solo (Vance et al.,1987). A mesma quantidade de solo não foi fumigada, fazendo-se a extração direta com $\mathrm{K}_{2} \mathrm{SO}_{4}$ a $0,5 \mathrm{M}$. Os 
extratos de solo obtidos, fumigado e não fumigado, foram submetidos à digestão com solução de dicromato de potássio. Em seguida foi adicionado indicador ferroína e procedeu-se à titulação com solução padronizada de sulfato ferroso amoniacal. Através da diferença entre o volume excedente (o que sobra do dicromato) das amostras fumigadas e não fumigadas, calculou-se o carbono extraível. Para o cálculo final utilizou-se a relação: Biomassa-C $=2,64 \times \mathrm{Ec}$, onde $\mathrm{Ec}=\mathrm{C}$ extraível do solo fumigado - $\mathrm{C}$ extraível do não fumigado (expresso em $\mu \mathrm{gCg}^{-1}$ de solo).

\subsubsection{Análise do nitrogênio da biomassa microbiana.}

Foi utilizado o mesmo método da fumigação-extração da análise do carbono da biomassa microbiana. Os extratos de solo obtidos, fumigados e não fumigados, foram submetidos à digestão sulfúrica e depois à destilação, titulando-se com $\mathrm{H}_{2} \mathrm{SO}_{4}$ a 0,0025M (Brookes et al., 1985).

\subsubsection{Análise da atividade microbiana por respirometria}

Amostras de $100 \mathrm{~g}$ de solo foram transferidas para frascos apropriados (bem vedados), umidecidas com $\mathrm{H}_{2} \mathrm{O}$ destilada em volume correspondente a $60 \%$ da capacidade de retenção de água do solo. Mediu-se o $\mathrm{CO}_{2}$ liberado pela respiração, o qual reagiu com $\mathrm{NaOH} 0,1 \mathrm{~N}$ e foi titulado com $\mathrm{HCl} 1 \mathrm{~N}$, tendo como indicador fenolftaleina, após 4 dias de incubação a $25-28^{\circ} \mathrm{C}$. Foram mantidos frascos controle ou branco, que não continham amostra de solo. $\mathrm{O}$ cálculo foi feito baseado na diferença entre o volume de $\mathrm{HCl}$ consumido pelas amostras e pelo "branco" e expresso em $\mu \mathrm{g} \mathrm{CO}_{2} \mathrm{~g}^{-1} \mathrm{dia}^{-1}$.

\subsubsection{Análise do teor de nitrogênio na parte aérea.}

Após a secagem da parte aérea, procedeu-se à moagem e homogenização para determinação do teor de $\mathrm{N}$ pelo método micro-Kjeldähl (Bremner, 1965). 


\subsubsection{Análise do teor de $\mathbf{P}$ na parte aérea.}

A determinação do teor de $P$ na parte aérea foi feita por emissão atômica empregando-se o espectrômetro de plasma JY50P-Jobin Yvon - ICP, após digestão clorídrica do material vegetal (Bataglia et al., 1978).

\subsubsection{Carbono orgânico total}

O método se baseia na oxidação do $C$ orgânico pelo dicromato de potássio. $\mathrm{O}$ excesso de dicromato do $\mathrm{C}$ orgânico é determinado por titulação de óxido-redução com $\mathrm{Fe}^{+2}$. O C orgânico é obtido pela diferença entre $\circ \mathrm{Fe}^{+2}$ gasto na titulação da prova em branco e aquele gasto para oxidar o $\mathrm{C}$ da amostra (Walkley, 1947).

\subsubsection{Quociente Metabólico}

O quociente metabólico foi calculado pela razão entre a respiração basal e a biomassa microbiana-C ( Pirt, 1975; Anderson \& Domsch, 1978).

3.1.12 Relação carbono da biomassa microbiana : carbono orgânico $\left(\mathrm{C}_{\text {mic }}: \mathrm{C}_{\text {org }}\right)$

A relação $\mathrm{C}_{\text {mic }}$ : $\mathrm{C}_{\text {org }}$ foi obtida pela razão entre o carbono da biomassa microbiana e o C orgânico do solo.

\subsubsection{Relação carbono da biomassa microbiana : nitrogênio da biomassa microbiana-N ( $\left.C_{\text {mic }}: N_{\text {mic }}\right)$}

A relação Cmic : Nmic foi obtida pela razão entre a biomassa microbiana-C e a biomassa microbiana-N.

\subsubsection{Análise da colonização micorrízica}

A determinação da colonização micorrízica foi realizada segundo método de Phillips \& Hayman (1970), no qual se faz o clareamento das raízes pelo 
aquecimento em solução de $\mathrm{KOH}$ a $10 \%$, seguido da acidificação com $\mathrm{HCl}$ diluído e da coloração com azul de tripano a 0,05\%. A quantificação da colonização micorrízica foi feita pela observação da presença de estruturas fúngicas dentro das raízes, na região do córtex, através do método da placa quadriculada (Giovanetti \& Mosse, 1980).

\subsubsection{Quantificação de esporos de FMA no solo}

A determinação do número de esporos de FMA foi realizada após extração dos esporos de $50 \mathrm{~g}$ de solo pelo método do peneiramento úmido, sequido de centrifugação em sacarose a 70\% (Gerdemann \& Nicolson, 1963).

\subsection{Isolamento e caracterização de bactérias endofíticas diazotróficas}

Os frascos que demonstraram crescimento positivo, ou seja, presença de película, foram estocados em meio sólido + óleo mineral, sendo utilizados para isolamento e caracterização. Para proceder ao isolamento, as películas foram retiradas com uma alça de platina e transferidas para um novo meio semi-sólido até que uma nova película fosse formada. Nesta fase, as películas foram transferidas para placas com meio sólido específico para cada diazotrófico acrescido de $20 \mathrm{mg}$ de extrato de levedura por litro. Para purificação final, as películas foram transferidas para placas com meio batata. Foram feitas várias repicagens para obtenção de culturas puras. Foi utilizado meio NFb-glucose como única fonte de carbono a fim de separar Azospirillum brasiliense de Herbaspirillum spp. Foi realizado teste de redução de acetileno (ARA), a fim de verificar a capacidade de fixação de nitrogênio "in vitro". A morfologia das culturas foi observada microscopicamente. As culturas também foram observadas em contraste de fase a fim de se distinguir os gêneros Herbaspirillum e Azospirillum, pois os últimos possuem grânulos de poli-hidroxibutirato que brilham quando observados. As culturas puras foram mantidas em meio sólido com óleo mineral. 


\subsection{Interação de genótipos de trigo e bactérias diazotróficas endofíticas}

O ensaio foi realizado utilizando-se tubos de ensaio de $200 \mathrm{ml}$ contendo solução de Hoagland \& Arnon (1950) sem N e $0,6 \%$ de ágar. Foram empregados 20 isolados, com 3 repetições. As bactérias foram inoculadas antes da solidificação do ágar, após atingir a fase log de crescimento em meio $\mathrm{JNFb}$, sendo utilizado $1 \mathrm{ml}$ por tubo. As testemunhas não receberam inóculo. As bactérias foram inoculadas no genótipo do qual foram originalmente isoladas. Foram testados 7 isolados com o genótipo ITD-19 e 13 isolados com o IAC-24. Como referência foram usadas 2 estirpes bem caracterizadas, sendo estas Z-67 de Herbaspirillum seropedicae e, SP-59b de Azospirillum lipoferum, cedidas gentilmente pela Embrapa-CNPAB (Tabela 3).

As sementes foram desinfestadas pela metodologia descrita por Döbereiner et al. (1995). Após a desinfestação, as sementes foram prégerminadas em placas de Petri, contendo meio batata para verificar a ausência de contaminantes, e só então transferidas para os tubos de ensaio. Este ensaio foi realizado em condições artificiais de luminosidade, em uma sala de crescimento de plantas, por um período de 30 dias. As plantas foram colhidas, secas em estufa a $60^{\circ} \mathrm{C}$ e pesadas para determinação da massa da matéria seca da parte aérea. Posteriormente foram moídas para determinação do teor de $\mathrm{N}$ na parte aérea pelo método micro-Kjeldähl (Bremner, 1965). O sistema radicular das plantas foi lavado e determinou-se o comprimento da raiz principal.

\subsection{Interação de fungos micorrízicos arbusculares e bactérias diazotróficas endofíticas.}

Foram selecionados dois isolados bacterianos, isolados $n^{\theta} 3$ e $n^{\theta} 7$ (Tabela 3) pertencentes ao gênero Herbaspirillum spp. testados no genótipo ITD-19, baseado nos resultados do experimento anterior (item 3.3); e dois isolados de FMAs, pertencentes ao gênero Acaullospora spp. (IAC-13) e 
Glomus spp. (IAC-22) respectivamente. O genótipo de trigo utilizado foi o ITD19.

As sementes foram desinfestadas, pré-germinadas em placas de petri, e transferidas para tubos de ensaio contento isolado bacteriano (conforme descrito no item 3.3). Após 7 dias, foram transplantadas para vasos de 2,5 litros contendo areia esterilizada como substrato, em casa de vegetação. Os vasos com FMA receberam cerca de 6000 esporos por vaso, pedaços de raiz colonizada e hifa. Nos vasos sem inoculação de FMA foi adicionado uma suspensão de solo isenta de propágulos de FMAs. Obtendo-se 11 tratamentos: 1.Herbaspirillum sp. $\mathrm{n}^{\theta} 3$, 2. Herbaspirillum sp. $\mathrm{n}^{\theta} 7,3$. Glomus sp., 4.Acaullospora sp., 5. Herbaspirillum sp. $\mathrm{n}^{\theta} 3+$ Glomus sp., 6. Herbaspirillum sp. $\mathrm{n}^{\theta} 3+$ Acaulospora sp, 7. Herbaspirillum sp. $\mathrm{n}^{0} 7+$ Glomus sp., 8. Herbaspirillum sp. $\mathrm{n}^{0} 7+$ Acaulospora sp., 9.controle sem nitrogênio, 10.controle com $\mathrm{N}$ e metade da quantidade de $\mathrm{P}$ da solução completa, 11.controle bem nutrido. $\mathrm{O}$ experimento foi mantido por um período de 2 meses (setembro e outubro) em casa de vegetação. As plantas receberam solução nutritiva (Furlani \& Furlani,1988) duas vezes por semana, e água esterilizada quando necessário. Os tratamentos com bactérias e o controle sem $\mathrm{N}$ receberam solução nutritiva sem nitrogênio e com metade da quantidade de $P$ da solução completa. Os tratamentos contendo somente FMA e testemunha-P receberam solução nutritiva com nitrogênio e metade da quantidade de $P$ da solução completa, e o controle bem nutrido recebeu solução nutritiva completa.

\subsection{Análises estatísticas.}

Os dados obtidos foram avaliados pelo programa Minitab, fazendo-se análise da variância seguida da comparação das médias pelo teste de t-student a $5 \%$, para comparação entre genótipos, levando-se em consideração o delineamento em faixas, com parcelas subdivididas e blocos ao acaso como foi instalado o experimento no campo. Para comparação entre as diferentes doses de $\mathrm{N}$ foram feitas regressões polinomiais. Para o experimento de seleção de 
estirpes "in vitro" foi utilizado o teste de Dunnett a 5\% para comparação entre os isolados e a testemunha. Para o experimento de interação entre FMAs e bactérias diazotróficas foram feitos contrastes ortogonais testados pelo teste $\mathrm{F}$ a $5 \%$ para comparação entre os tratamentos. 


\section{RESULTADOS E DISCUSSÃO}

\subsection{Microrganismos diazotróficos endofíticos.}

\subsubsection{Quantificação de microrganismos diazotróficos endofíticos em raízes de trigo.}

A análise da variância mostrou que a quantidade de microrganismos diazotróficos endofíticos nas raízes do trigo quando utilizado o meio de cultura $\mathrm{NFb}$; semi-específico para Azospirillum sp., JNFb; semi-específico para Herbaspirillum sp. e LGI-P semi-específico para Gluconacetobacter diazotrophicus, foi influenciada pelo genótipo da planta independentemente da dose de nitrogênio utilizada. Além disso, houve interação entre genótipos e doses, ou seja, os genótipos se comportaram diferentemente quanto ao número destes microrganismos em relação à adubação nitrogenada.

Nos três meios de cultivo empregados, o genótipo IAC-355 apresentou significativamente menor colonização radicular por diazotróficos endofíticos que os demais genótipos, os quais não diferiram entre si, quando avaliado o fator genótipo isoladamente, excluindo-se a influência de doses de $\mathrm{N}$ (Figura 1, tabela 1 do anexo). 


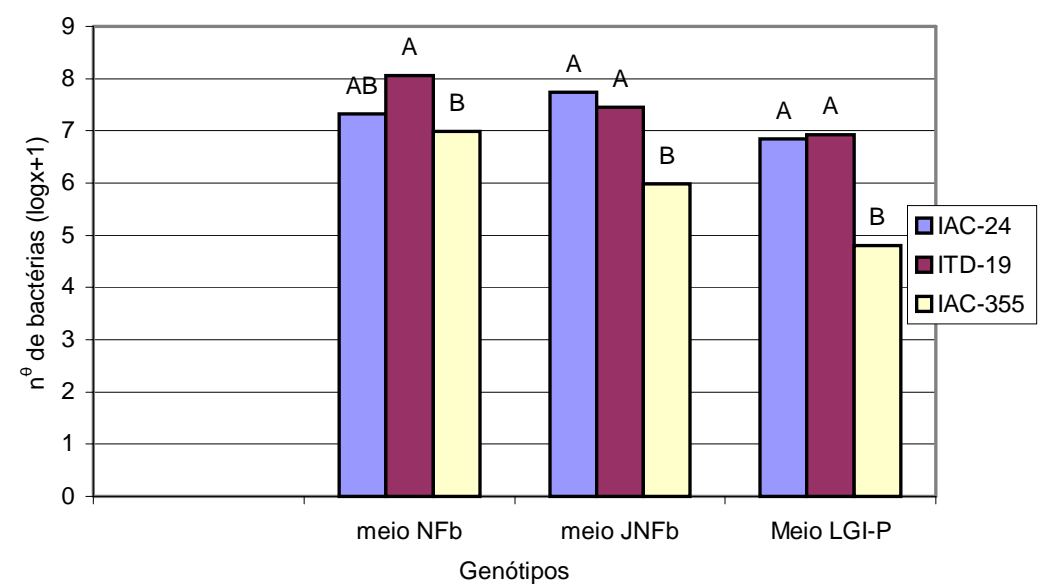

Figura 1 - Número de microrganismos diazotróficos endofíticos na raiz de três genótipos de trigo, obtidos nos meios de cultura NFb, semi-específico para Azospirillum sp., JNFb, semiespecífico para Herbaspirillum sp e LGI-P, semi-específico para Gluconacetobacter diazotrophicus. Letras iguais não diferem entre si pelo teste t-student dentro de cada meio de cultivo. Média de 9 repetições.

A quantidade de diazotróficos endofíticos no genótipo IAC-355 apresentou regressão linear ascendente, ou seja, houve aumento destes microrganismos com o aumento da dose de $\mathrm{N}$, quando utilizado o meio $\mathrm{NFb}$ para a quantificação (Figura 2, Tabela 1 do anexo). Para os demais genótipos, IAC-24 e ITD-19, o número de diazotróficos endofíticos não se alterou com a adição de $\mathrm{N}$.

Quando os genótipos foram comparados entre si na mesma dose de $\mathrm{N}$ empregando-se o meio de cultivo NFb, na ausência de $\mathrm{N}$ o genótipo IAC-355 diferiu significativamente dos demais, apresentando a menor quantidade de diazotróficos endofíticos, na dose de $60 \mathrm{~kg} \mathrm{ha}^{-1}$ de $\mathrm{N}$ o genótipo ITD-19 apresentou a maior quantidade de diazotróficos, e na dose de $120 \mathrm{~kg} \mathrm{ha}^{-1}$ de N o genótipo IAC-355 apresentou o maior número destes microrganismos diferindo significativamente do IAC-24.(Figura 2, Tabela 1 do anexo). 


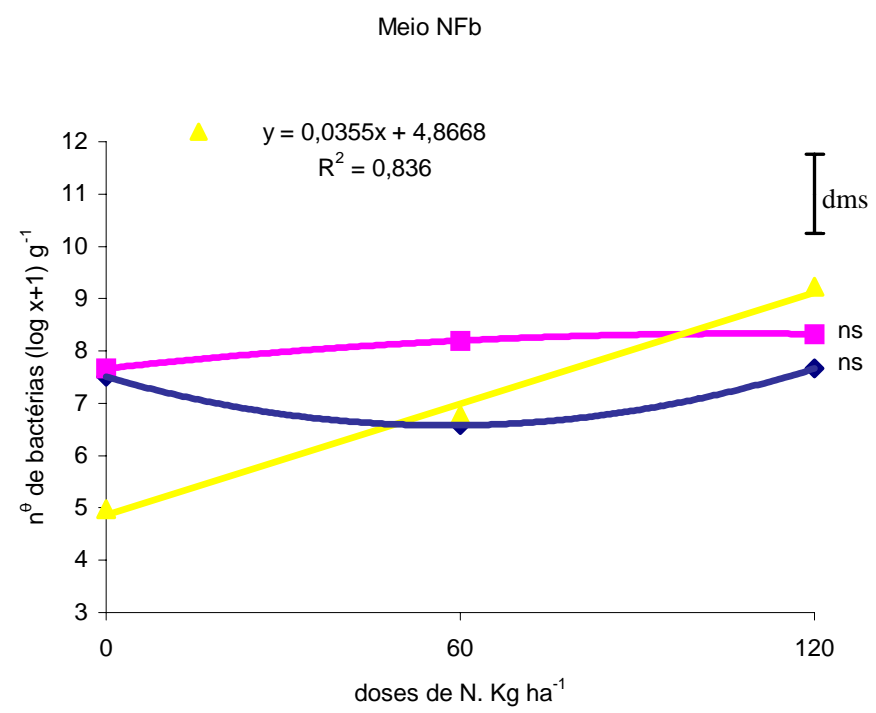

Figura 2 - Número de microrganismos diazotróficos endofíticos na raiz desinfestada superficialmente de três genótipos de trigo, IAC-24 (•), ITD-19 (ロ) e IAC-355 ( $)$ ), obtidos em meio $\mathrm{NFb}$ em relação à dose de $\mathrm{N}$ adicionada. dms- diferença mínima significativa pelo teste $\mathrm{t}$ a $5 \%$ para comparação entre cultivares em uma mesma dose de $\mathrm{N}$.

Com relação às doses de $\mathrm{N}$ adicionadas, a contagem de diazotróficos endofíticos em meio de cultivo JNFb, semi-específico para Herbaspirillum spp., apresentou ajuste linear ascendente com o aumento da quantidade de $\mathrm{N}$ para $\mathrm{o}$ genótipo IAC-355 (Figura 3, Tabela 1 do anexo), enquanto para os demais não houve ajuste, ou seja, não variou com o $\mathrm{N}$ adicionado.

Quando os genótipos foram avaliados em relação à mesma dose de $\mathrm{N}$, somente na ausência de $\mathrm{N}$ obteve-se diferença significativa entre os genótipos encontrando-se a menor quantidade de diazotróficos endofíticos no genótipo IAC-355 (Figura 3, Tabela 1 do anexo). 
Meio JNFb

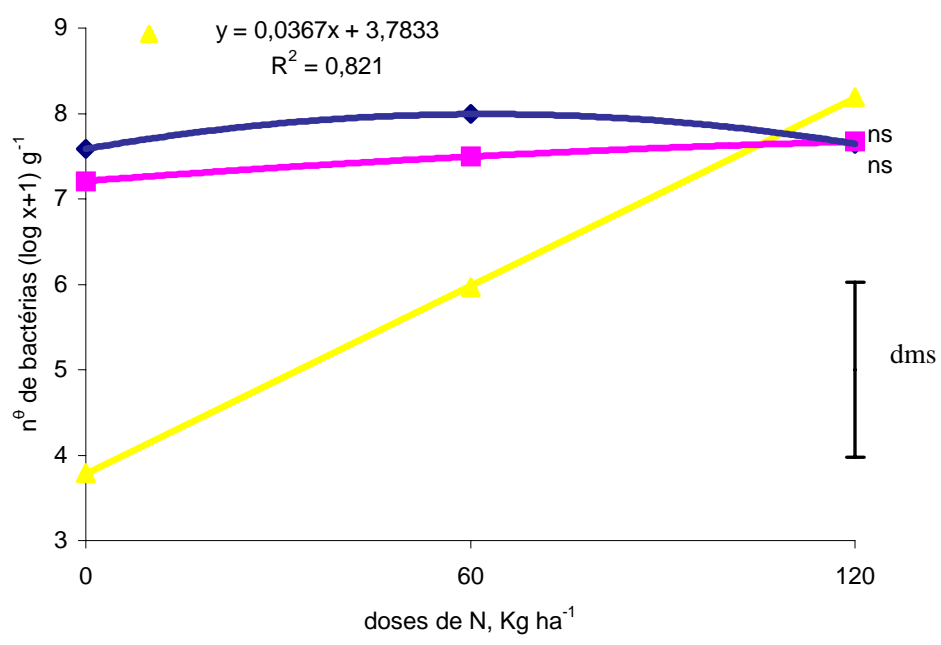

Figura 3 - Número de microrganismos diazotróficos endofíticos na raiz desinfestada superficialmente de três genótipos de trigo, IAC-24 (•), ITD-19 (®) e IAC-355 ( $)$ ), obtidos em meio JNFb em relação à dose de $\mathrm{N}$ adicionada. dms- diferença mínima significativa pelo teste $\mathrm{t}$ a $5 \%$ para comparação entre cultivares em uma mesma dose de $\mathrm{N}$.

A quantidade de diazotróficos endofíticos obtida em meio LGI-P, semiespecífico para Gluconacetobacter diazotrophicus, em relação à dose de N adicionada, mostrou um ajuste linear ascendente somente para o genótipo IAC355 (Figura 4, tabela 1 do anexo). Esse mesmo genótipo também apresentou a menor quantidade de diazotróficos endofíticos nas menores doses de $\mathrm{N}$, diferindo significativamente do genótipo IAC-24 e ITD-19 na dose 0 e $60 \mathrm{~kg} \mathrm{ha}^{-1}$ de N. Não houve diferença entre os genótipos empregados quando aplicado $120 \mathrm{~kg} \mathrm{ha}^{-1}$ de N (Figura 4, Tabela 1 do anexo). 


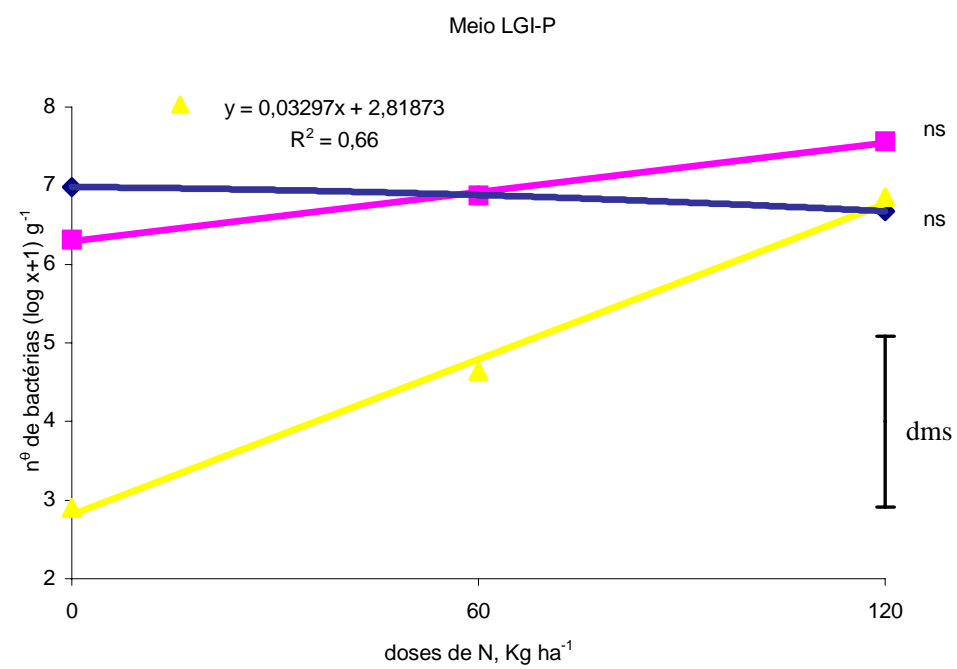

Figura 4 - Número de microrganismos diazotróficos endofíticos na raiz desinfestada superficialmente de três genótipos de trigo, IAC-24 (•), ITD-19 (₫) e IAC-355 ( $)$ ), obtidos em meio LGI-P em relação à dose de $\mathrm{N}$ adicionada. dms- diferença mínima significativa pelo teste $\mathrm{t}$ a $5 \%$ para comparação entre cultivares em uma mesma dose de $\mathrm{N}$.

Existe um consenso geral que o genótipo da planta é o fator chave para a fixação biológica do $\mathrm{N}$ conjuntamente com a seleção de estirpes eficientes (Reis et al., 2000). Confirmou-se que o genótipo da planta tem efeitos diferenciais na colonização da raiz por estas bactérias (Holl, 1983), realmente o genótipo IAC-355 apresentou menor quantidade de bactérias diazotróficas em todos os meios de cultivo utilizados, independentemente da dose de $\mathrm{N}$.

Quando se avaliou a interação entre genótipos e doses de N, no genótipo IAC-355 obteve-se a menor quantidade de diazotróficos endofíticos quando comparado ao ITD-19 e IAC-24 na ausência de N, em meio NFb, JNFb e LGI-P. Observou-se que houve estímulo nas populações destes microrganismos para o genótipo IAC-355 com o aumento na dose de $\mathrm{N}$ adicionada, o que não ocorreu para os demais genótipos.

Alguns trabalhos têm mostrado que o aumento na dose de $\mathrm{N}$ adicionada como adubo pode diminuir a quantidade de diazotróficos na raiz. Kirchhof et al. (1997), observaram que a quantidade de bactérias diazotróficas era menor, ou 
mesmo, indetectável em altos níveis de $\mathrm{N}$ mineral. $\mathrm{O}$ fertilizante nitrogenado pode alterar o estado fisiológico da planta e conseqüentemente afetar as populações destas bactérias (Muthukumarasamy et al., 1999). A atividade da nitrogenase em algumas espécies de diazotróficos endofíticos pode ser prejudicada por altos níveis de $\mathrm{NO}_{3}$ no meio de cultivo (Boddey \& Döbereiner, 1988). Em experimentos em campo ou em casa de vegetação, foram obtidas respostas positivas à inoculação, mesmo quando utilizaram-se altos níveis de fertilizante nitrogenado (Millet \& Feldman, 1984, Reynders \& Vlassak, 1982).

As contagens de microrganismos diazotróficos endofíticos, realizadas em três meios de cultivo semi-específicos, tiveram correlação positiva e significativa entre si, demonstrando que o número desses microrganismos foi afetado de forma semelhante pelos fatores estudados.

\subsubsection{Isolamento de bactérias diazotróficas endofíticas.}

Não foi obtido nenhum isolado das raízes do genótipo IAC-355, o que também apresentou menor número de microrganismos em todos os meios de cultivo utilizados (Figura 1).

Foram obtidos 8 isolados do gênero Azospirillum sp. e 12 isolados do gênero Herbaspirillum sp das raízes dos genótipos IAC-24 e ITD-19. A maioria dos isolados foi obtido nos tratamentos que não receberam fertilizante nitrogenado ou na dose intermédiária de $\mathrm{N}$ (Tabela 2). Isto confirma o efeito negativo de altos níveis de fertilizante nitrogenado sobre as populações de Azospirillum spp. e Herbaspirillum spp. O fato de a quantidade de bactérias endofíticas aumentarem nas raízes do genótipo IAC-355 com o aumento na dose de $\mathrm{N}$ adicionada, o que não ocorreu nos demais genótipos, não teve nenhuma relação com 0 isolamento das bactérias procuradas, já que neste genótipo nenhum isolado foi obtido. 
Tabela 2. Isolados de Herbaspirillum e Azospirillum obtidos do experimento de campo.

\begin{tabular}{ccc}
\hline $\begin{array}{c}\text { Doses de N/ } \\
\mathrm{kg} \mathrm{ha}^{-1}\end{array}$ & Genótipos \\
& IAC-24 & ITD-19 \\
\hline & Isolados-Herbaspirillum spp. \\
0 & IAC-HT-1 \\
0 & IAC-HT-2 \\
0 & IAC-HT-3 & \\
0 & IAC-HT-4 \\
0 & IAC-HT-5 & \\
60 & IAC-HT-6 \\
60 & IAC-HT-7 & \\
120 & IAC-HT-8 & IAC-HT-10 \\
& IAC-HT-9 & IAC-HT-11 \\
0 & Isolados-Azospirillum spp. \\
60 & IAC-AT-1 \\
60 & IAC-AT-2 & \\
60 & IAC-AT-3 & IAC-AT-5 \\
60 & IAC-AT-6 \\
120 & IAC-AT-4 & IAC-AT-8 \\
\hline
\end{tabular}

Vários autores sugerem que plantas que não respondem à adubação nitrogenada podem estar associadas a bactérias diazotróficas obtendo $\mathrm{N}$ pela fixação biológica, como por exemplo à cana-de-açúcar. Oliveira et al.(1994) após 9 anos de pesquisa observaram que a quantidade de $\mathrm{N}$ acumulado no solo sob plantio de cana-de-açúcar foi maior que a quantidade inicial de $\mathrm{N}$. Pode-se sugerir que no presente trabalho não foi obtido nenhum isolado das bactérias pesquisadas no genótipo IAC-355 devido ao fato deste ser eficiente e 
altamente responsivo ao nitrogênio, o que não ocorre para os demais genótipos utilizados.

Nas condições estudadas não foi identificado nenhum isolado de Gluconacetobacter diazotrophicus nas raízes do trigo, apesar de o meio de cultivo semi-específico (LGI-P) ter possibilitado alta contagem de microrganismos endofiticos na raiz (Figura 4). Essa bactéria, embora já isolada da raiz de outras gramíneas, ainda não foi observada colonizando plantas de trigo.

Os meios de cultivo semi-sólido e que não contém $\mathrm{N}$ são amplamente utilizados por diversos pesquisadores a fim de verificar a ocorrência e isolar bactérias diazotróficas associativas devido às condições de microaerofilia (Dobereiner \& Day, 1976). Existe pouca informação sobre as fontes de carbono utilizadas por esses microrganismos, sobre os valores de $\mathrm{pH}$, da pressão osmótica, e das condições do seu habitat na rizosfera das plantas, nas raízes ou dentro dos tecidos da planta hospedeira. A composição dos meios de cultura é baseada em suposições obtidas dos trabalhos disponíveis (Reis et al., 2000).

Os meios de cultivo empregados são realmente semi-específicos para avaliar a ocorrência de bactérias diazotróficas endofíticas, pois superestimam o número de tais microrganismos. Além disso, observou-se neste trabalho que após algumas repicagens da película formada nos tubos de ensaio contendo meio de cultivo semi-sólido sem $\mathrm{N}$, muitos isolados não mais se desenvolveram nos tubos, não sendo observada a presença da película característica, prejudicando o isolamento de um suposto diazotrófico.

Stoltzfus et al. (1997), analisaram 133 isolados obtidos de plantas de arroz, pelo uso de meio semi-sólido e constataram que 120 desses isolados não apresentaram atividade de redução do acetileno e genes nifD. Segundo Barraquio et al.(1997) aproximadamente $90 \%$ das bactérias isoladas de raízes desinfestadas superficialmente utilizando-se um meio de cultura semi-sólido, que não contém nitrogênio, não são bactérias diazotróficas. 
Provavelmente, o macerado das raízes para obtenção das diluições, possui um residual de nitrogênio que é acrescentado ao meio de cultivo, o que possibilita também o crescimento de microrganismos que não são diazotróficos. Pode-se notar na fase de isolamento que os isolados obtidos foram originários das maiores diluições.

Os meios de cultivo também não foram específicos para o isolamento do gênero da bactéria diazotrófica desejada. Muitos microrganismos isolados no meio chamado de "específico" para Azospirillum spp ou Herbaspirillum spp. não apresentavam as características do gênero procurado. Além disso, o meio de cultivo LGI-P, que contém alta concentração de sacarose, idealizado para o isolamento de $G$. diazotrophicus, possibilitou amplo crescimento de microrganismos endofíticos sem que, entretanto, tenha sido obtido um isolado da espécie desejada. Segundo Yanni et al. (1997) a comunidade de diazotróficos cultiváveis é extremamente variada e somente poucas bactérias foram identificadas e caracterizadas.

\subsubsection{Seleção do isolado eficiente "in vitro"}

Uma das variáveis que contribui para complexidade das respostas à inoculação é o genótipo da planta que freqüentemente mostra respostas diferentes, além do efeito da estirpe inoculada, o que foi constatado pelos resultados obtidos. Os isolados obtidos foram testados no genótipo do qual foram originalmente isolados (Tabela 3). 
Tabela 3. Isolados utilizados no experimento "in vitro"

$$
\text { Isolados }
$$

Número de referência Genótipo-ITD-19 Genótipo-IAC-24

\begin{tabular}{cll}
\hline 1 & IAC-AT-5 & IAC-AT-2 \\
2 & IAC-HT-10 & IAC-HT-1 \\
3 & IAC-HT-12 & IAC-AT-1 \\
4 & IAC-AT-6 & IAC-HT-7 \\
5 & IAC-AT-7 & IAC-HT-8 \\
6 & IAC-AT-8 & IAC-AT-4 \\
7 & IAC-HT-11 & IAC-HT-2 \\
8 & Testemunha & IAC-HT-3 \\
9 & Z-67 & IAC-HT-4 \\
10 & SP-59b & IAC-HT-5 \\
11 & & IAC-HT-6 \\
12 & & IAC-HT-9 \\
13 & & IAC-AT-3 \\
14 & & Testemunha \\
15 & & Z-67 \\
16 & & SP-59b \\
\hline
\end{tabular}

Com relação ao crescimento da raiz principal, observou-se que as plantas do genótipo ITD-19, colonizadas por qualquer dos isolados testados, apresentaram comprimento de raízes significativamente maior em relação à testemunha (Figura 5, tabelas 2 e 3 do anexo). O mesmo efeito não foi obtido no genótipo IAC-24, no qual apenas o isolado 6 causou significativamente maior comprimento radicular que a testemunha. Os isolados 5 e 13 diferiram significativamente da testemunha, pois causaram diminuição no comprimento da raiz principal (Figura 5, Tabelas 2 e 3 do anexo). 
Genótipo- ITD-19

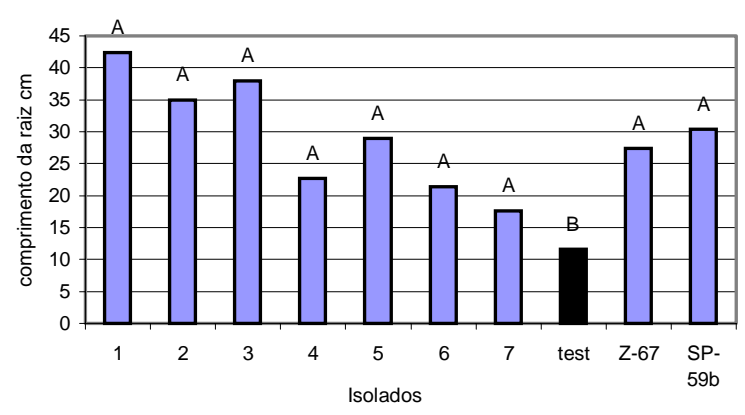

Genótipo- IAC-24

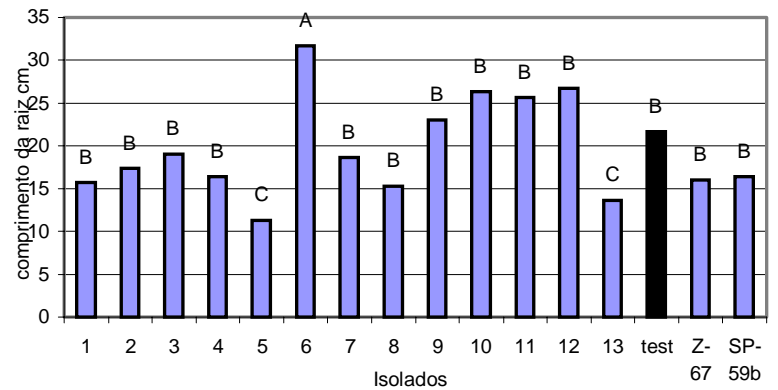

Figura 5 - Comprimento da raiz principal dos genótipos de trigo ITD-19 e IAC-24 submetidos a diferentes isolados de bactérias diazotróficas endofíticas em relação à testemunha. Letras iguais não diferem entre si pelo teste de Dunnett a 5\%. Z-67: estirpe tipo de Herbaspirillum seropedicae e, SP-59b: estirpe tipo de Azospirillum lipoferum.

Há evidências que sugerem que os benefícios causados por estas bactérias podem ser devido à produção de fitormônios e não somente pela FBN. Foram observados vários efeitos na morfologia das raízes, como aumento no comprimento, no número e na superfície, aumento na absorção mineral, que podem estar relacionados a substâncias promotoras de crescimento secretadas pela bactéria (Martin et al., 1989). Bhattarai \& Hess (1998) concluíram que ao lado da FBN, o efeito de estimulação do crescimento pela bactéria no desenvolvimento das raízes, nos primeiros estágios de crescimento da planta, pode ser responsável pelo impacto positivo da inoculação em trigo. Foi verificado um aumento nos pêlos radiculares de plantas de trigo devido a auxinas secretadas por Azospirillum sp.(Dobbelaere et al.,1999). 
Quanto à altura das plantas no genótipo ITD-19, os isolados 1, 2, 5, 6 e 7 propiciaram significativamente maior altura que a testemunha. No genótipo IAC24 somente o isolado número 10 foi significativamente maior que a testemunha, e o número 5 foi menor que a testemunha (Figura 6, Tabela 2 e 3 do anexo).

Genótipo- ITD-19

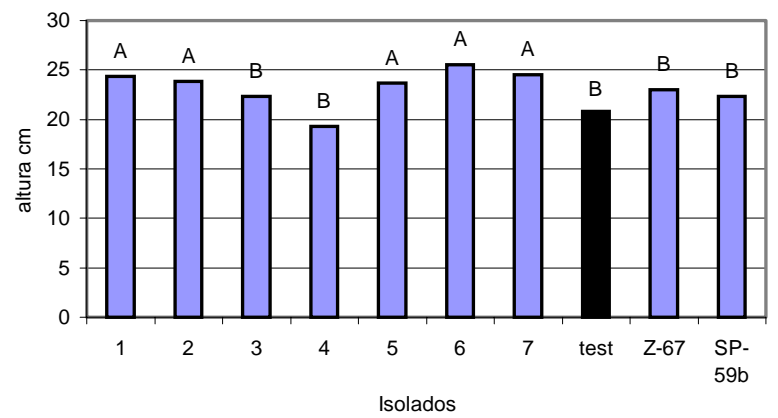

Genótipo- IAC-24

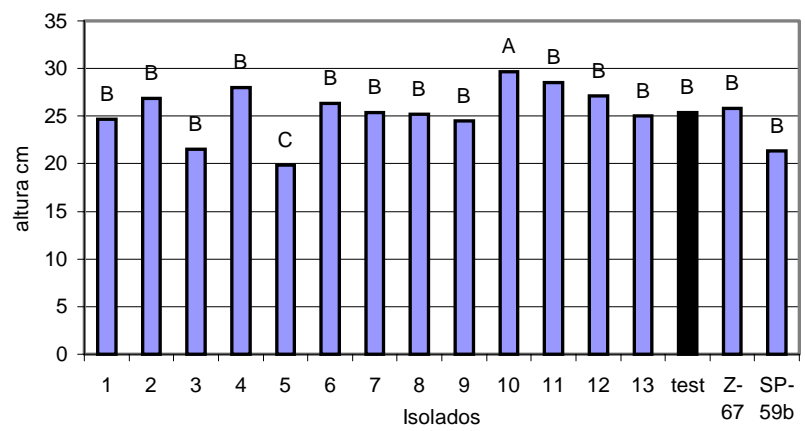

Figura 6 - Altura dos genótipos de trigo ITD-19 e IAC-24 submetidos a diferentes isolados de bactérias diazotróficas endofíticas em relação à testemunha. Letras iguais não diferem entre si pelo teste de Dunnett a 5\% Z-67: estirpe tipo de Herbaspirillum seropedicae e, SP-59b: estirpe tipo de Azospirillum lipoferum.

Quando se avaliou a massa da matéria seca da parte aérea não foram obtidas diferenças significativas entre as plantas colonizadas por qualquer dos isolados utilizados e a testemunha, em ambos os genótipos (Figura 7, tabelas 2 e 3 do anexo). Mas, notou-se que a maioria dos isolados proporcionou aumento da matéria seca, sendo que os tratamentos com os isolados 3 e 7 no genótipo ITD-19 apresentaram um aumento de 14\%, e o isolado 6 no genótipo IAC-24 
causou um aumento de $32 \%$ em relação à testemunha (Figura 7, tabela 2 e 3 do anexo).

Genótipo- ITD-19

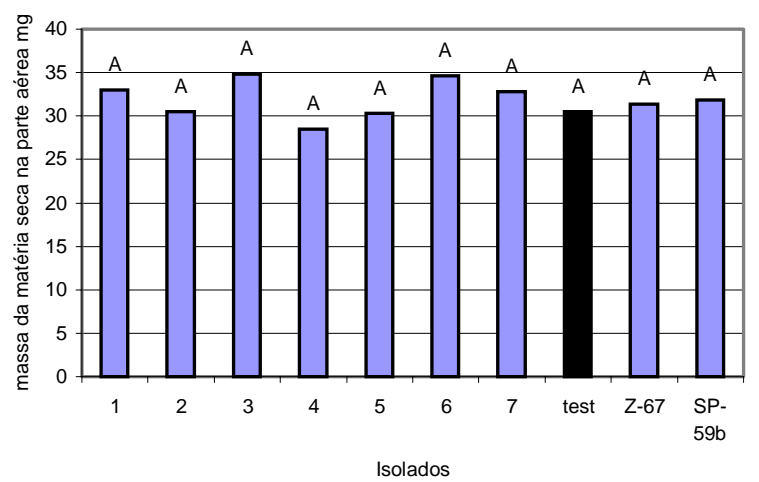

Genótipo-IAC-24

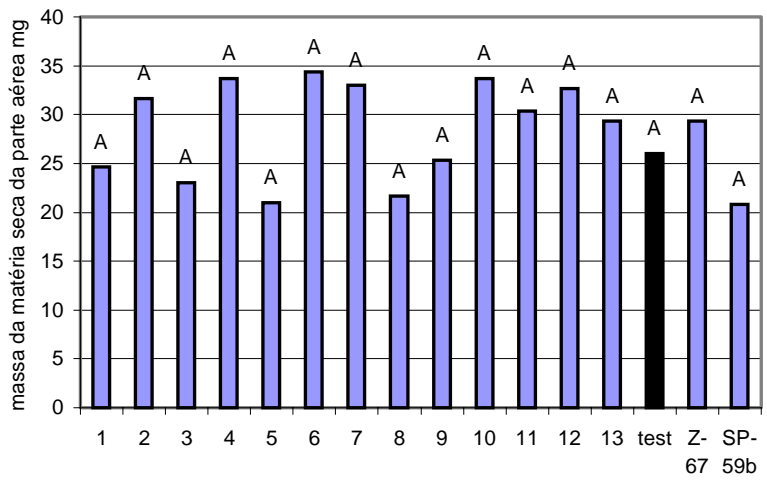

Isolados

Figura 7 - Massa da matéria seca da parte aérea de trigo dos genótipos ITD-19 e IAC-24 submetidos a diferentes isolados de bactérias diazotróficas endofíticas em relação à testemunha. Letras iguais não diferem entre si pelo teste de Dunnett a 5\%. Z-67: estirpe tipo de Herbaspirillum seropedicae e, SP-59b: estirpe tipo de Azospirillum lipoferum.

$\mathrm{Na}$ análise do teor de $\mathrm{N}$ na parte aérea da planta, somente as plantas do genótipo ITD-19 colonizadas pelo isolado número 3 , diferiu significativamente da testemunha, apresentando maior teor de $N$ (Figura 8, tabelas 2 e 3 do anexo). 
Genótipo- ITD-19

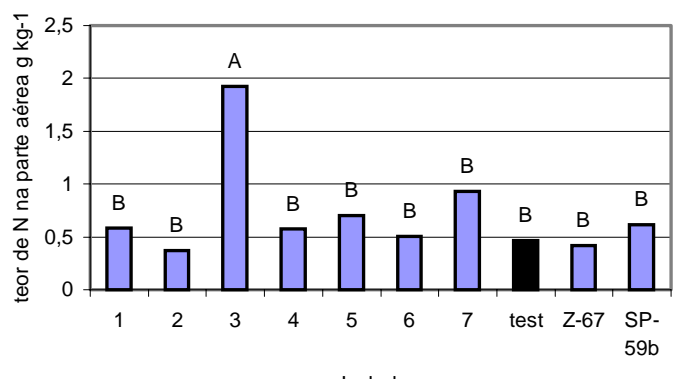

Isolados

Genótipo- IAC-24

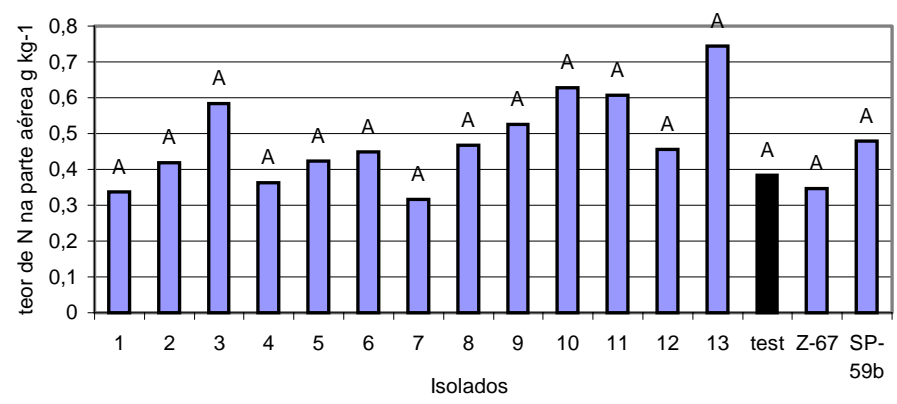

Figura 8 - Teor de $\mathrm{N}$ na parte aérea nos genótipos ITD-19 e IAC-24 submetidos a diferentes isolados de bactérias diazotróficas endofíticas em relação à testemunha. Letras iguais não diferem entre si pelo teste de Dunnett a 5\%. Z-67: estirpe tipo de Herbaspirillum seropedicae e, SP-59b: estirpe tipo de Azospirillum lipoferum.

Os resultados obtidos mostram que dos isolados testados poucos foram os que propiciaram algum benefício ao trigo, como também demonstrado por Baldani et al. (2000) em estudo de seleção de Herbaspirillum seropedicae em plantas de arroz, onde de 80 isolados de Herbaspirillum seropedicae testados, apenas 4 foram capazes de causar algum benefício em plantas de arroz. Os autores sugerem que a seleção de bactérias diazotróficas endofíticas deveria ser intensificada, levando-se em consideração os fatores ambientais e o genótipo da planta utilizada na associação. Realmente, um dos pontos cruciais para seleção e manejo destes diazotróficos é a especificidade planta-bactéria, como também constatado por Salomone \& Dobereiner (1996) e Scholoter \& Hartmann (1997). Reis et al. (2000) também sugerem como estratégia para 
intensificação da seleção de bactérias diazotróficas associativas, o uso de experimentos em condições gnobióticas com várias bactérias e um genótipo.

Resta ainda conhecer os efeitos propiciados pelos isolados obtidos neste trabalho em condições não axênicas, verificando sua competitividade em nível de campo, uma vez que a colonização e o estabelecimento das bactérias diazotróficas associativas são afetadas de maneiras diferentes dependendo das populações naturais do solo (Baldani et al., 1986). Em solos com pequena ou ausente comunidade nativa de diazotróficos, as respostas à inoculação são mais consistentes e a recomendação de inoculação pode fazer parte do manejo da cultura (Okon, 1985). 


\subsection{Análise da colonização micorrízica e quantificação de esporos de FMAs na cultura do trigo.}

A análise da variância mostrou que a colonização das raízes por fungos micorrízicos foi influenciada pelo genótipo da planta, independente da quantidade de $\mathrm{N}$ utilizada, e que houve interação entre genótipos e doses de $\mathrm{N}$. A colonização por FMAs também foi influenciada pela quantidade de adubo nitrogenado aplicado, excluindo-se o genótipo da planta.

O genótipo IAC-355 apresentou significativamente maior colonização radicular por FMAs que os demais genótipos independentemente da dose de $\mathrm{N}$ aplicada (Figura 9, tabela 4 do anexo).

FMA

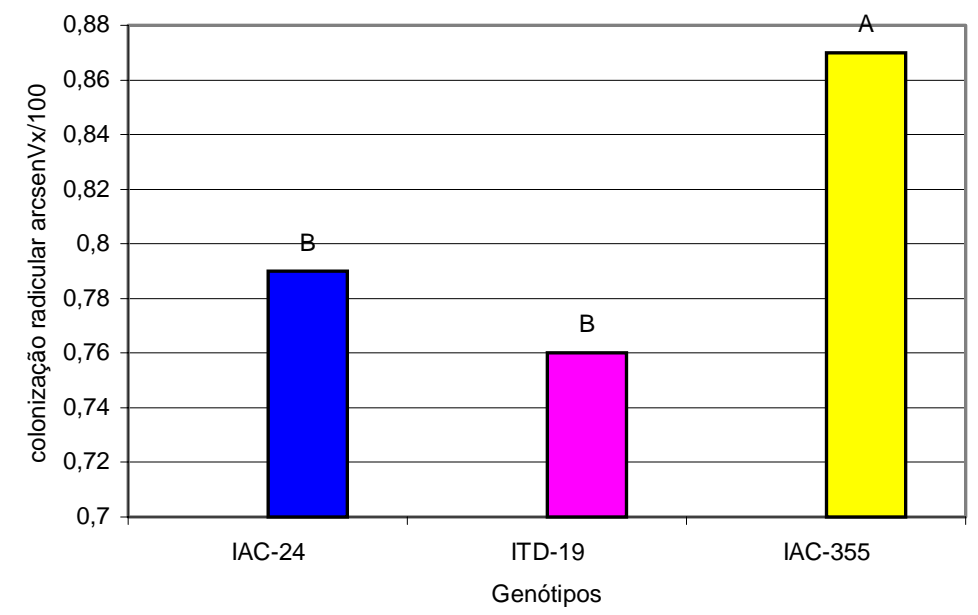

Figura 9 - Colonização radicular por FMAs nos cultivares de trigo IAC-24, ITD-19 e IAC-355. Letras iguais não diferem pelo teste t-student a 5\%. Média de 9 repetições.

Observou-se um ajuste linear ascendente na colonização micorrízica nos genótipos ITD-19 e IAC-24 em relação às doses de N adicionadas (Figura 10, tabela 4 do anexo), enquanto que no IAC-24 a colonização não se alterou com o $\mathrm{N}$ aplicado. 
Os genótipos comportaram-se diferentemente quando submetidos a $120 \mathrm{~kg}$ de $\mathrm{N} \mathrm{ha}^{-1}$, pois nesta dose o genótipo IAC-355 diferiu significativamente dos demais genótipos, apresentando uma maior colonização por FMAs (Figura 10, Tabela 4 do anexo).

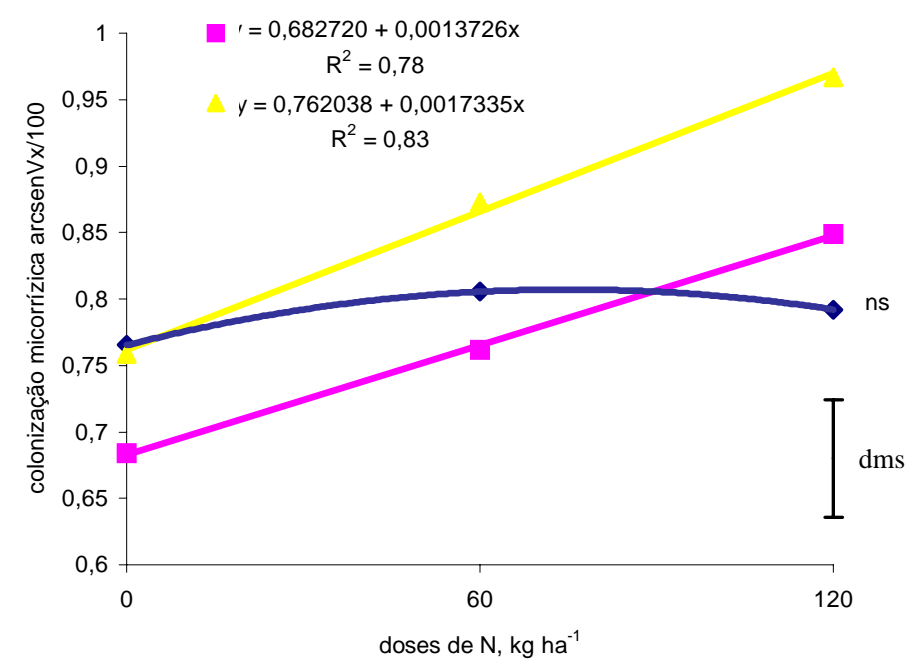

Figura 10 - Colonização micorrízica em relação à dose de $\mathrm{N}$ adicionada para os genótipos IAC$24(\diamond)$, ITD-19 ( $($ ) e IAC-355 ( $)$. dms- diferença mínima significativa pelo teste $\mathrm{t}$ a $5 \%$ para comparação entre cultivares em uma mesma dose de $\mathrm{N}$.

Quando se avaliou o fator doses isoladamente obteve-se uma regressão linear ascendente, ocorrendo aumento da colonização por FMAs com a dose de $\mathrm{N}$ utilizada (Figura 11, tabela 4 do anexo). 


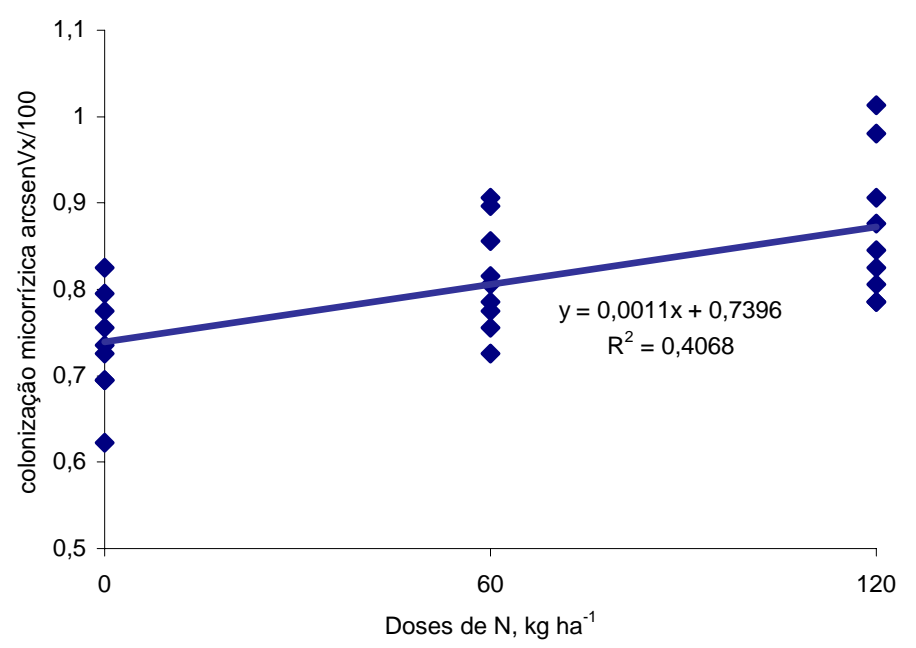

Figura 11 - Colonização micorrízica em trigo em relação à dose de $N$ adicionada $(n=9)$.

O fato de ter havido aumento da colonização radicular com maior fornecimento de $\mathrm{N}$ ao solo pode estar relacionado a algum desbalanço nutricional nas plantas, principalmente nos genótipos IAC-355 e ITD-19. A dependência micorrízica está mais relacionada ao peso e espessura das raízes do que ao teor de nutrientes, mas Azcon \& Ocampo (1981) constataram que as plantas de trigo com baixa colonização apresentaram baixos níveis de $\mathrm{N}$ e $\mathrm{P}$, levando a acreditar que este desbalanço nutricional esteja associado com a formação da micorriza.

Já foi constatada a influência do genótipo da planta na interação com FMAs. O trigo, devido à morfologia de suas raízes (raiz fasciculada), apresenta pouca dependência micorrízica. Alguns trabalhos demonstram que a cultivar de trigo é mais determinante para o sucesso da interação do que a espécie do fungo (Hetrick et al., 1996). A ausência ou a baixa colonização por FMAs em algumas variedades de trigo está relacionada à baixa exsudação de açúcares pela raiz (Azcon \& Ocampo, 1981).

Através da análise da variância observou-se que a quantidade de esporos de FMAs no solo rizosférico de trigo foi influenciada pelo genótipo da 
planta, independentemente da dose de $\mathrm{N}$ utilizada e que houve interação entre os genótipos e as doses de $\mathrm{N}$ avaliadas.

Quando os genótipos foram comparados entre si, excluindo-se o fator doses de $\mathrm{N}$, observou-se menor número de esporos no solo cultivado com o genótipo ITD-19 (Figura 12, tabela 4 do anexo).

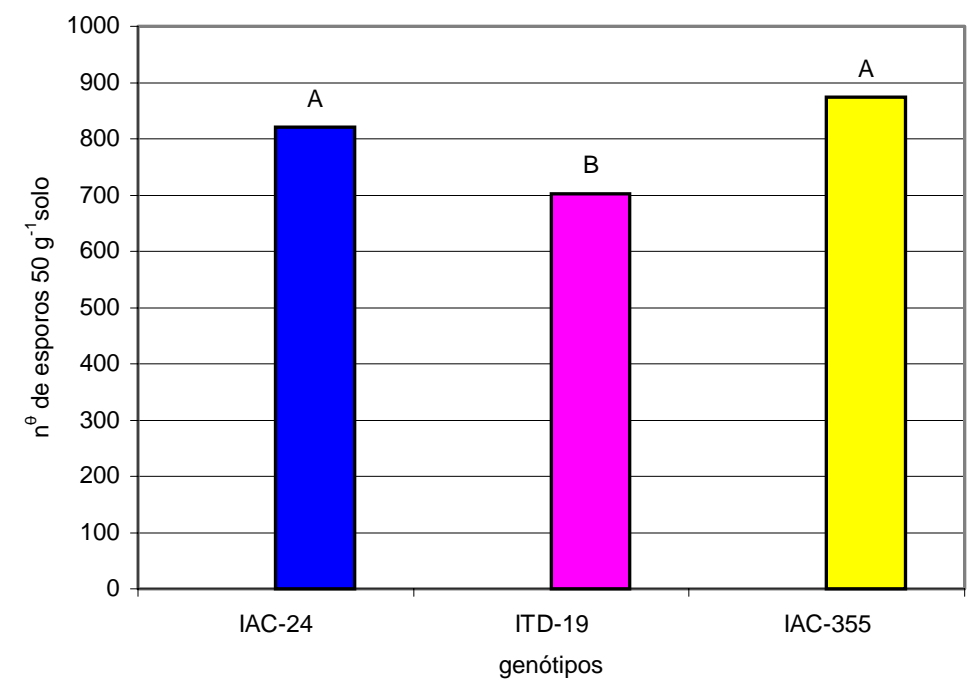

Figura 12 - Número de esporos de FMAs no solo sob influência dos genótipos IAC-24, ITD-19 e IAC-355. Letras iguais não diferem pelo teste t-student a 5\%. Média de 9 repetições.

Obteve-se um ajuste linear descendente entre o número de esporos no solo sob influência dos genótipos IAC-24 e IAC-355 e a quantidade de N aplicada. Já no genótipo ITD-19 houve um ajuste quadrático com ponto de máxima na dose de $73 \mathrm{~kg} \mathrm{ha}^{-1}$ de $\mathrm{N}$ (Figura 13, tabela 4 do anexo).

Os genótipos diferiram entre si em relação à dose de $\mathrm{N}$ adicionada somente quando não foi aplicado adubo nitrogenado. O solo sob influência do genótipo ITD-19 apresentou significativamente menor número de esporos que o solo sob influencia do IAC-24 ou IAC-355 na ausência de N. (Figura 13, Tabela 4 do anexo). 


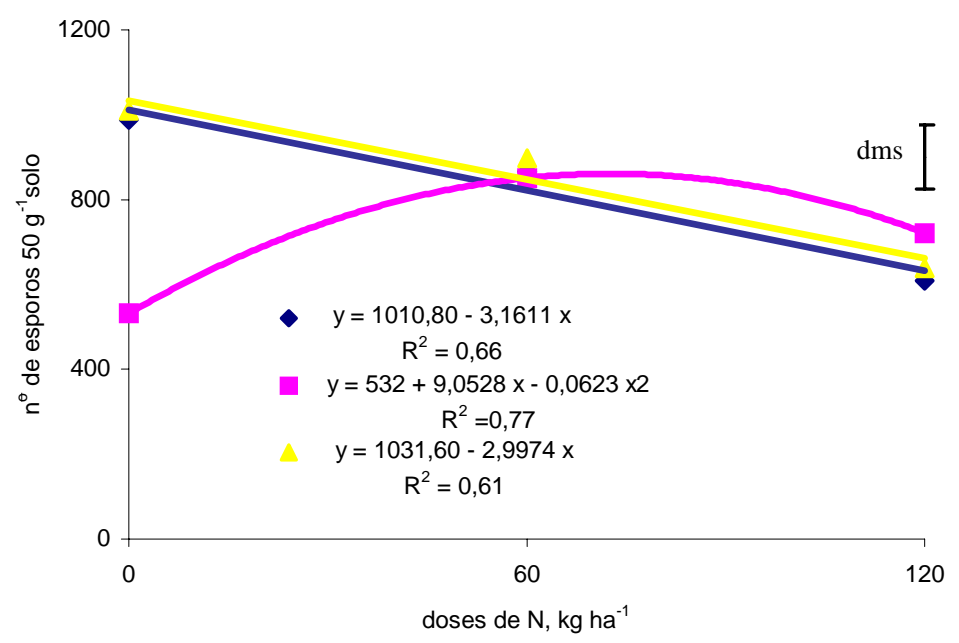

Figura 13 - Número de esporos de FMAs no solo sob influência dos genótipos IAC-24 (•), ITD19 ( ( ) e IAC-355 ( $)$. em relação à dose de $\mathrm{N}$ adicionada. dms- diferença mínima significativa pelo teste t a $5 \%$ para comparação entre cultivares em uma mesma dose de $\mathrm{N}$.

\subsection{Estudo da comunidade e da atividade microbianas do solo.}

\subsubsection{Comportamento da biomassa microbiana.}

Através da análise da variância observou-se que o C da biomassa microbiana não foi afetado pelo genótipo do trigo assim como pela quantidade de adubo nitrogenado. Porém, houve interação entre genótipos e doses de $\mathrm{N}$.

Os genótipos diferiram significativamente entre si, na ausência de $\mathrm{N}$ adicionado. O genótipo IAC-355 apresentou a maior biomassa-C quando comparado ao IAC-24, não diferindo do ITD-19 (Figura 14, Tabela 5 do anexo). 


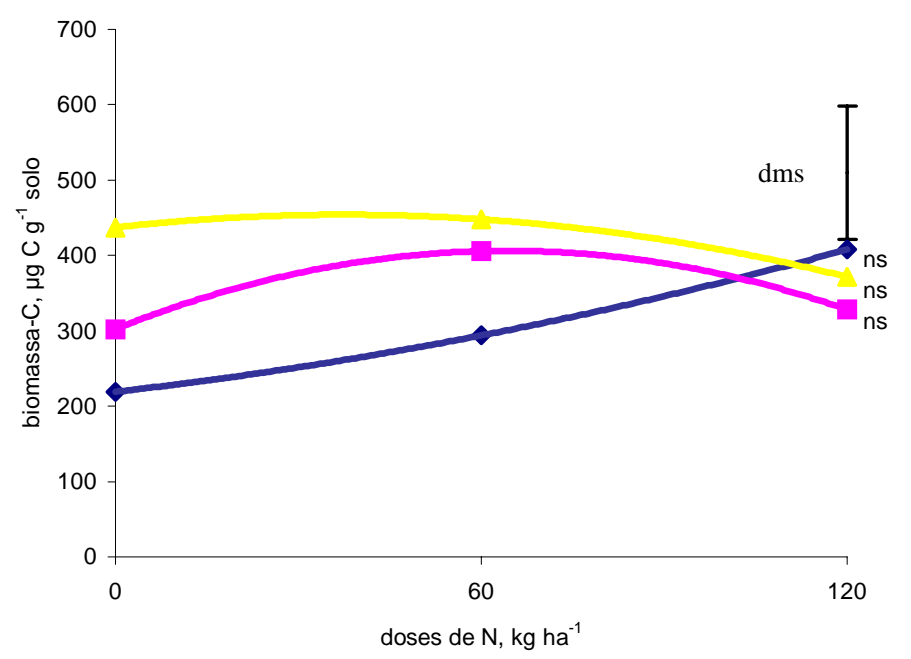

Figura 14 - Carbono da biomassa microbiana em relação à dose de $\mathrm{N}$ adicionada para os genótipos de trigo IAC-24 (•), ITD-19 (•) e IAC-355 ( $)$ ). dms- diferença mínima significativa pelo teste t a $5 \%$ para comparação entre cultivares em uma mesma dose de $\mathrm{N}$.

Esse efeito provavelmente foi devido a diferenças nos exsudatos radiculares dos dois genótipos, sendo que o genótipo IAC-355 possibilitou maior crescimento da biomassa-C que o IAC-24, quando avaliados na ausência de adubo nitrogenado.

A quantidade de $\mathrm{N}$ da biomassa microbiana do solo foi influenciada pelo genótipo da planta independente da dose de $\mathrm{N}$ utilizada. Houve interação entre os genótipos e a quantidade de adubo nitrogenado, obtendo-se diferenças significativas entre genótipos quando avaliados em relação à mesma dose de N.

No solo sob influência do genótipo IAC-24 houve significativamente menor biomassa-N que no solo sob influencia dos demais genótipos, quando se avaliou o fator genótipo excluindo a quantidade de $\mathrm{N}$ adicionada (Figura 15, tabela 5 do anexo). 


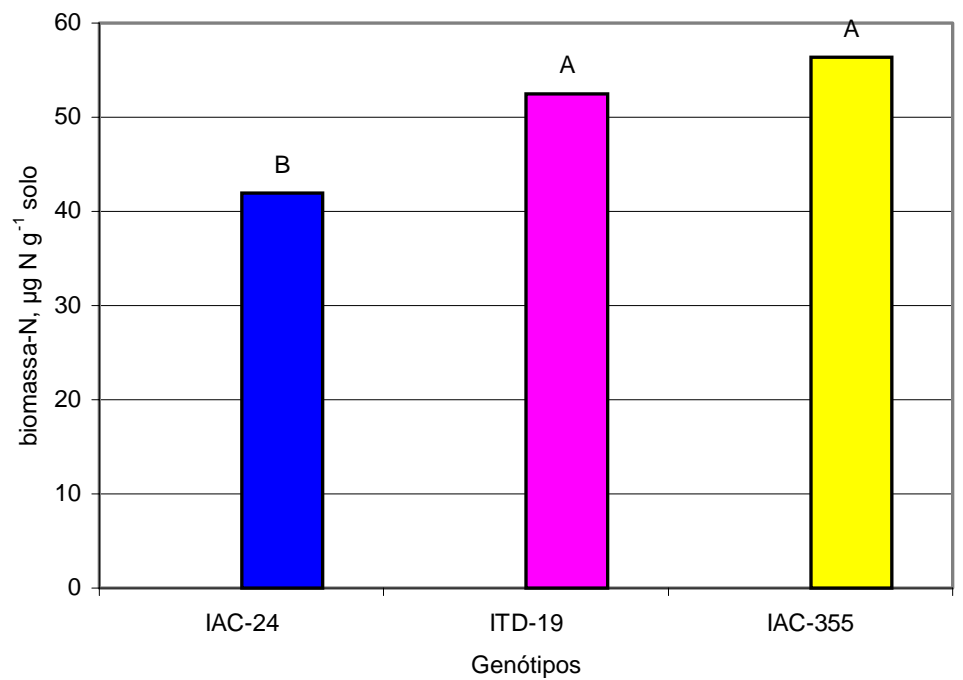

Figura 15 - Nitrogênio da biomassa microbiana do solo sob influência dos genótipos de trigo IAC-24, ITD-19 e IAC-355. Letras iguais não diferem entre si pelo teste t-student a 5\%. Média de 9 repetições.

Em relação à dose de $\mathrm{N}$ adicionadas, observou-se um ajuste linear descendente para o $\mathrm{N}$ da biomassa do solo cultivado com o genótipo IAC-24, enquanto para os demais genótipos, a biomassa- $\mathrm{N}$ não variou com a quantidade de $\mathrm{N}$ adicionada (Figura 16, tabela 5 do anexo).

Quando os genótipos foram comparados entre si, submetidos à mesma dose de $\mathrm{N}$, observou-se que na dose de $60 \mathrm{~kg} \mathrm{ha}^{-1}$ o solo sob influência do genótipo ITD-19 apresentou significativamente menor biomassa-N que o solo sob influência do genótipo IAC-355. O mesmo ocorreu com o genótipo IAC-24 o qual diferiu significativamente dos demais genótipos na dose de $120 \mathrm{~kg} \mathrm{ha}^{-1}$ de $\mathrm{N}$ (Figura 16, Tabela 5 do anexo). 


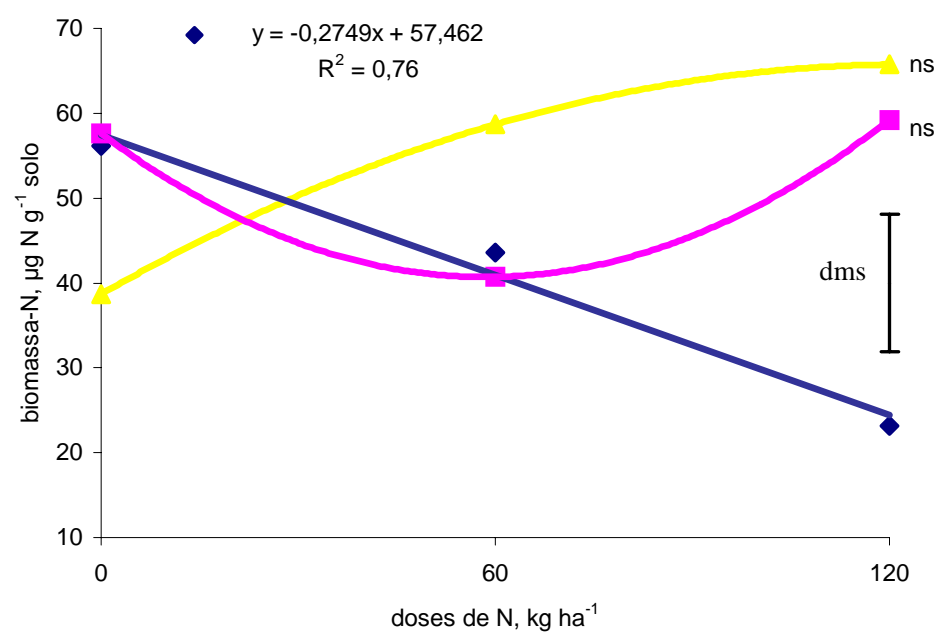

Figura 16 - Nitrogênio da biomassa microbiana do solo sob influência dos genótipos de trigo IAC-24 (•), ITD-19 (₫) e IAC-355 ( $)$ em relação à dose de $\mathrm{N}$ adicionada. dms- diferença mínima significativa pelo teste t a $5 \%$ para comparação entre genótipos em uma mesma dose de N.

Verificou-se que o genótipo de trigo influenciou a biomassa- $\mathrm{N}$, provavelmente devido a diferenças na morfologia ou fisiologia das raízes ou na rizodeposição pelas raízes. Os exsudatos radiculares podem influenciar o pH e o potencial redox na rizosfera, o que certamente afeta a comunidade microbiana. As diferenças genotípicas são determinantes para aquisição de nutrientes pelas plantas (Marschener, 1998), e conseqüentemente, a qualidade e a quantidade de exsudatos radiculares.

$\mathrm{Na}$ ausência de adubo nitrogenado não houve diferenças entre os genótipos quando se avaliou a biomassa- $\mathrm{N}$ do solo. Entretanto nas doses $60 \mathrm{e}$ $120 \mathrm{~kg} \mathrm{ha}^{-1}$ de $\mathrm{N}$, ou seja, quando se adicionou $\mathrm{N}$ no solo, o solo sob influencia do genótipo IAC-355 apresentou maior biomassa-N. A maior quantidade de $\mathrm{N}$ microbiano pode indicar maior potencial de mineralização de nitrogênio (Whitmore, 1996). 
A assimilação microbiana depende do carbono orgânico disponível. Existem evidências de que o carbono orgânico liberado pelas raízes é responsável por este processo de assimilação e também pela propagação dos microrganismos na rizosfera (Mengel,1996). Joergensen et al. (1994), observaram um aumento na biomassa- $\mathrm{N}$ quando foi utilizado altos níveis de $\mathrm{N}$ em combinação com o carbono orgânico excretado pelas raízes na cultura do trigo. Provavelmente, a liberação de compostos fotossintetisados pelas raízes tem um impacto direto na assimilação do nitrato, amônia e $\mathrm{N}_{2}$ pelos microrganismos.

A análise da variância mostrou que a relação Cmic:Nmic não foi influenciada pelo genótipo da planta ou pela quantidade de $\mathrm{N}$ adicionada, quando avaliou-se estes dois fatores isoladamente. Porém houve interação entre genótipos e doses de $\mathrm{N}$.

Obteve-se um ajuste quadrático com ponto de máxima na dose de $59 \mathrm{Kg}$ $\mathrm{ha}^{-1}$, quando se avaliou a relação Cmic:Nmic em função da quantidade de adubo nitrogenado para o genótipo ITD-19 (Figura 17, tabela 5 do anexo).

Os genótipos se comportaram de modo diferente somente quando submetidos a $120 \mathrm{~kg} \mathrm{ha}^{-1}$ de $\mathrm{N}$, na presença do IAC-24 obteve-se a maior relação Cmic:Nmic. Nas menores doses de $\mathrm{N}$ não foram observadas diferenças significativas entre os genótipos avaliados (Figura 17, tabela 5 do anexo). 


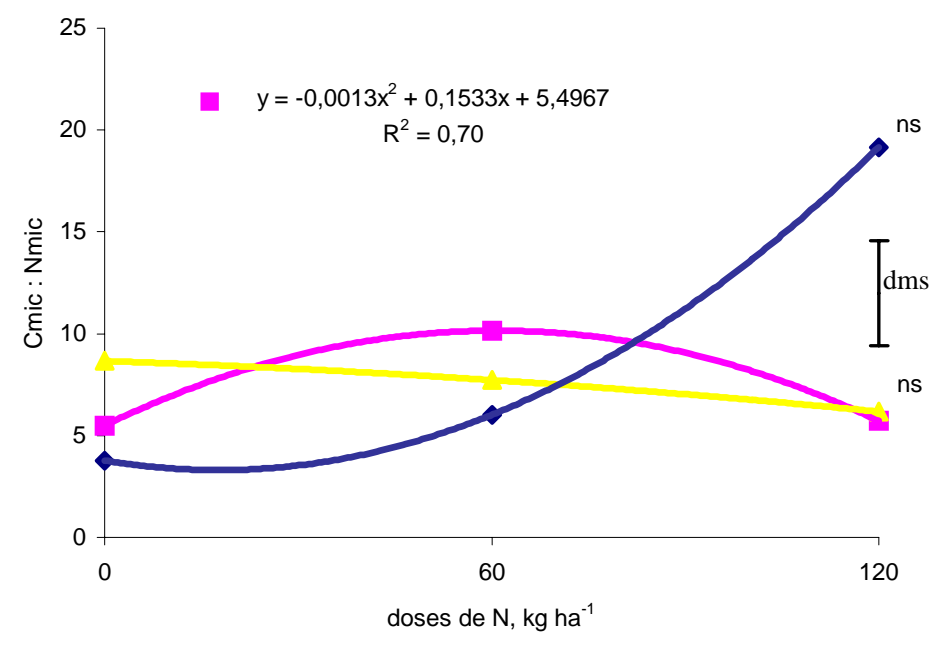

Figura 17 - Relação Cmic:Nmic do solo em função da dose de $\mathrm{N}$ adicionada,empregando os genótipos de trigo IAC-24 (•), ITD-19 (•) e IAC-355 ( $($ ). dms- diferença mínima significativa pelo teste t a $5 \%$ para comparação entre cultivares em uma mesma dose de $\mathrm{N}$.

$\mathrm{Na}$ presença do genótipo IAC-24 houve maior relação Cmic:Nmic na dose de $120 \mathrm{~kg} \mathrm{ha}^{-1}$, devido à baixa biomassa-N microbiana do solo. Uma alta relação Cmic:Nmic pode indicar menor potencial de mineralização do $\mathrm{N}$ e conseqüentemente menos nutrientes disponíveis para as plantas.

A relação Cmic:Corg não sofreu influência do diferentes genótipos ou da quantidade de $\mathrm{N}$ adicionada, quando estes fatores foram avaliados isoladamente. Entretanto, observou-se interação entre os genótipos e as doses de $\mathrm{N}$ utilizadas.

Obteve-se um ajuste quadrático com ponto de máxima na dose de $63 \mathrm{Kg}$ $\mathrm{ha}^{-1}$, quando se avaliou o solo cultivado com o genótipo ITD-19, em relação à dose de $\mathrm{N}$ aplicada (Figura 18, tabela 5 do anexo).

No tratamento com o genótipo IAC-355 houve a maior relação Cmic:Corg, diferindo significativamente do IAC-24, quando avaliados na ausência de adubo nitrogenado (Figura 18, Tabela 5 do anexo). 


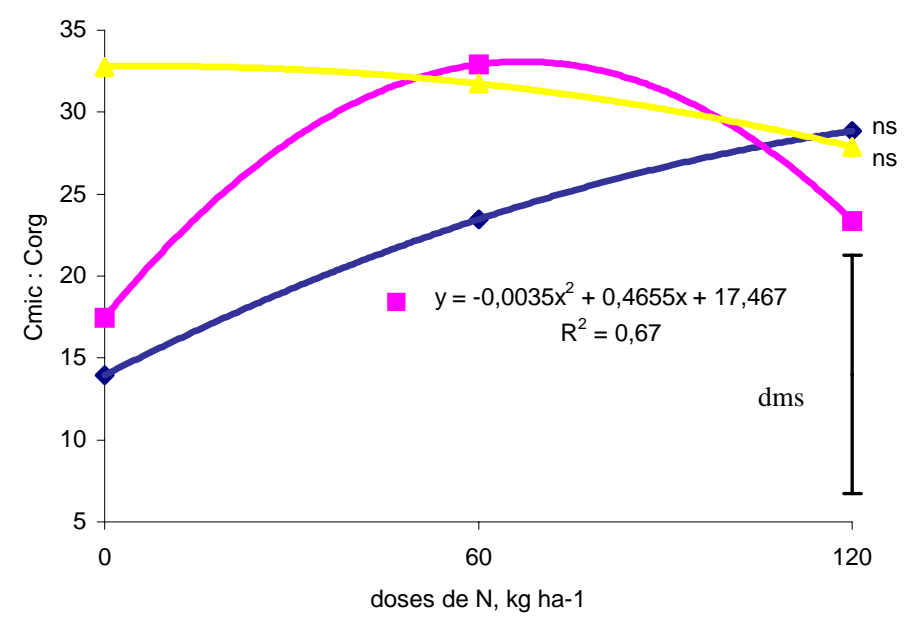

Figura 18 - Relação Cmic:Corg do solo em função da dose de $\mathrm{N}$ adicionada, empregando os genótipos de trigo IAC-24 (•), ITD-19 ( $\bullet$ ) e IAC-355 ( $>$ ). dms- diferença mínima significativa pelo teste t a $5 \%$ para comparação entre cultivares em uma mesma dose de $\mathrm{N}$.

A matéria orgânica do solo é composta pela parte lábil e pela parte recalcitrante ao ataque de microrganismos. A biomassa microbiana pertence ao carbono orgânico lábil, sendo responsável pelo fluxo de carbono no solo, tanto na fase gasosa $\left(\mathrm{CO}_{2}\right)$ como na fase de carbono orgânico dissolvido. As mudanças na relação Cmic:Corg refletem a qualidade do carbono orgânico do solo, a eficiência da conversão do carbono microbiano, as perdas de carbono no solo e a estabilização do carbono orgânico pela fração mineral do solo (Sparling, 1992). Esta relação permite obter informações sobre a dinâmica do carbono no solo. Uma relação Cmic:Corg alta indica acúmulo de carbono no solo, e uma baixa relação Cmic:Corg indica que existem perdas de carbono no solo.

Somente na ausência de fertilizante nitrogenado e na presença do genótipo IAC-355 houve maior relação Cmic:Corg no solo, o que pode ser explicado pela alta biomassa-C microbiano, enquanto que com o IAC-24 houve menor relação devido à baixa biomassa-C. Pode-se concluir que houve um 
acúmulo de $C$ orgânico na presença do genótipo IAC-355, enquanto que com o IAC-24 houve perdas de C, na ausência de fertilizante nitrogenado. Quando se adicionou $\mathrm{N}$ ao solo, houve um equilíbrio no $\mathrm{C}$ do solo.

\subsubsection{Atividade microbiana}

A análise da variância mostrou que a atividade microbiana medida pela respirometria não sofreu influência dos genótipos ou das doses de $\mathrm{N}$ utilizadas e que também não houve interação entre genótipos e a quantidade de $\mathrm{N}$ aplicada (Figura 19, Tabela 6 do anexo).

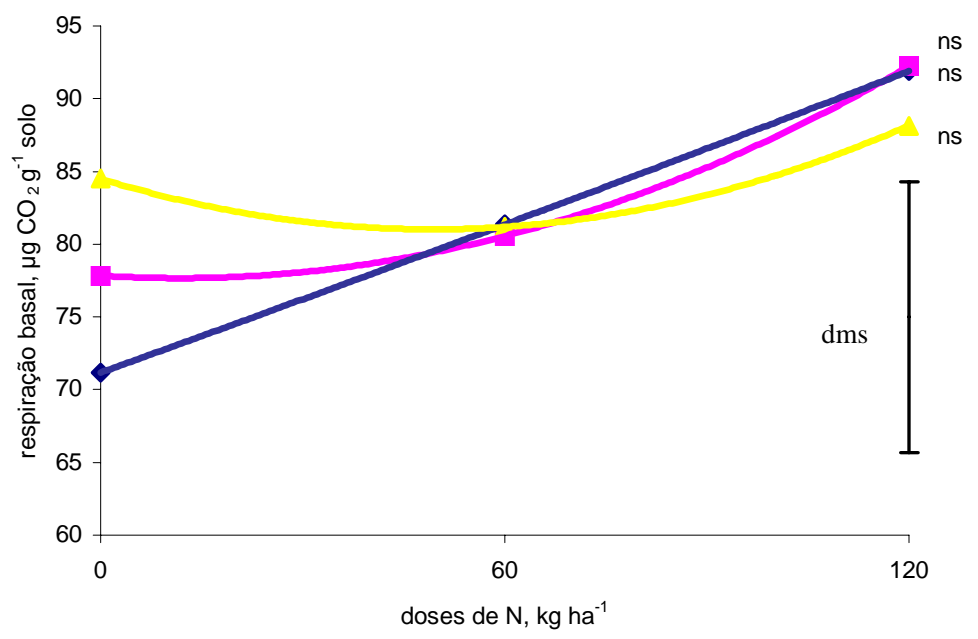

Figura 19 - Respiração basal do solo sob influência de três genótipos IAC-24 (•), ITD-19 (घ) e IAC-355 ( $)$ de trigo em relação à dose de $\mathrm{N}$ adicionada ao solo. dms- diferença mínima significativa pelo teste t a $5 \%$ para comparação entre cultivares em uma mesma dose de $\mathrm{N}$.

A respiração basal do solo é um indicador da qualidade do carbono orgânico disponível aos microrganismos heterotróficos. Quanto maior a quantidade de $\mathrm{CO}_{2}$ liberada por unidade de peso de solo maior a quantidade de substrato assimilável para o desenvolvimento da biomassa microbiana. 
Verificou-se um aumento na respiração com a quantidade de $\mathrm{N}$ adicionada, porém não foi estatisticamente significativa. Thirukkumaram \& Parkinson (2000), concluíram que a adição de uréia aumenta a respiração basal do solo devido ao aumento do $\mathrm{pH}$. Este aumento da atividade microbiana foi atribuído a maior quantidade de carbono que os microrganismos conseguem decompor, resultante da alcalinização do solo, sugerindo um efeito sinérgico por permitir fácil acesso da microbiota a outros nutrientes inorgânicos que são normalmente indisponíveis em baixos níveis de $\mathrm{pH}$.

$\mathrm{Na}$ análise do quociente metabólico não foi observada influência da quantidade de $\mathrm{N}$ adicionada, mas houve efeito do genótipo da planta (Figura 20, tabela 6 do anexo), quando estes dois fatores foram analisados isoladamente. Houve interação entre genótipos e doses de $\mathrm{N}$, ou seja, os genótipos comportaram-se de forma diferente quando submetidos à mesma dose de $\mathrm{N}$.

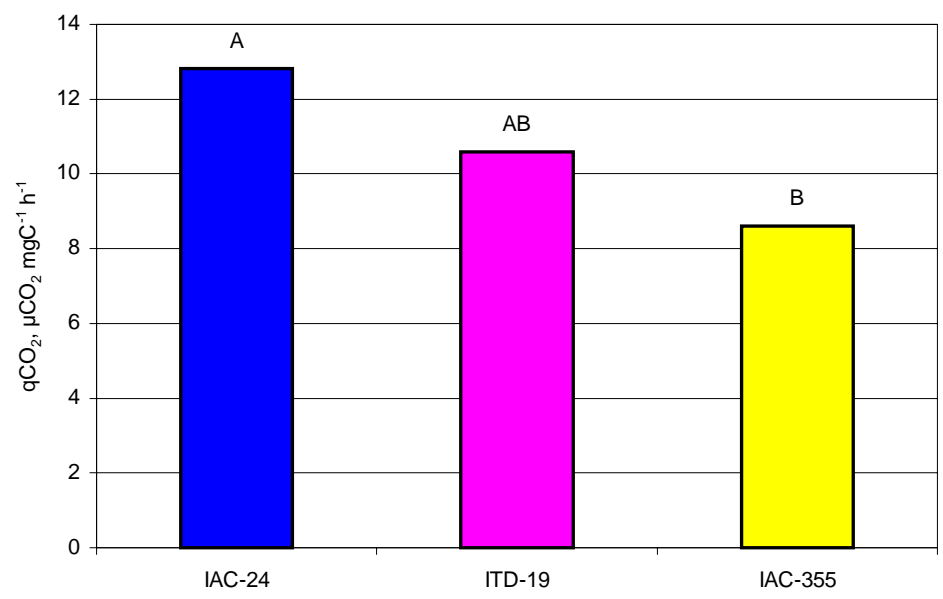

Figura 20 - Quociente metabólico da microbiota do solo empregando os genótipos de trigo IAC24, ITD-19 e IAC-355. Letras iguais não diferem entre si pelo teste t-student a 5\%. Média de 9 repetições.

No solo cultivado com o genótipo IAC-355, o quociente metabólico foi significativamente menor que no solo cultivado com o genótipo IAC-24 na ausência de adubo nitrogenado (Figura 21, Tabela 6 do anexo). 


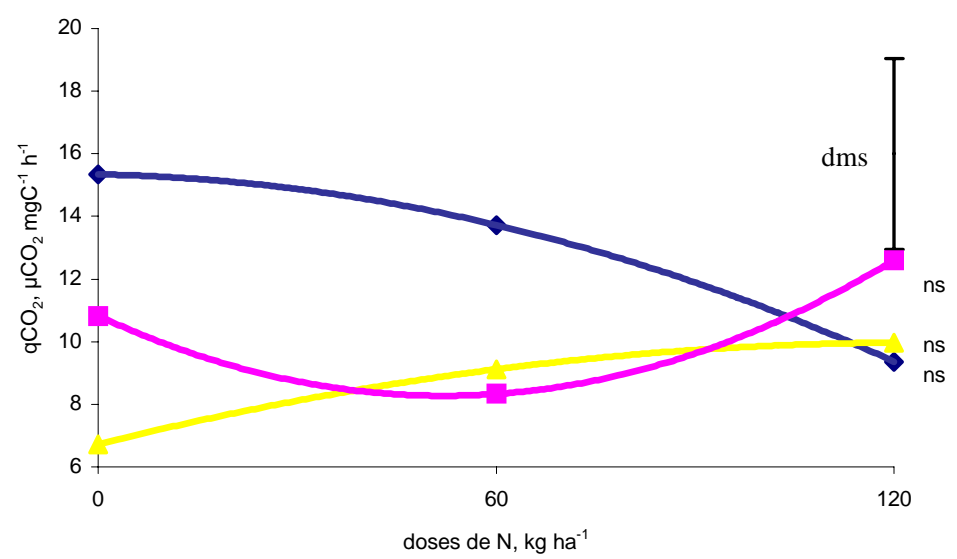

Figura 21 - Quociente metabólico em relação à dose de $\mathrm{N}$ adicionada para os genótipos de trigo IAC-24 (•), ITD-19 ( $\bullet$ ) e IAC-355 ( $>$ ). dms- diferença mínima significativa pelo teste t a 5\% para comparação entre cultivares em uma mesma dose de $\mathrm{N}$.

O quociente metabólico, que corresponde à quantidade de $\mathrm{CO}_{2}$ liberado por unidade de biomassa microbiana produzida, indica a eficiência da comunidade microbiana em reter ou incorporar carbono da biomassa ou perdêlo para a atmosfera na forma de $\mathrm{CO}_{2}$. Maior $\mathrm{qCO}_{2}$ implica em maiores perdas de $\mathrm{C}$ para a atmosfera na forma de $\mathrm{CO}_{2}$ por unidade de biomassa microbiana produzida, sendo que um menor $\mathrm{qCO}_{2}$ sugere maior eficiência na utilização do carbono do solo.

Insam et al. (1991) sugerem que em áreas com maiores teores de $C$ pode ocorrer aumento da biomassa microbiana e diminuição na atividade metabólica. O genótipo IAC-355 apresentou menor $\mathrm{qCO}_{2}$ que o IAC-24 na ausência de adubo nitrogenado. Este efeito foi devido à alta biomassa-C no solo sob influência do genótipo IAC-355 na ausência de $\mathrm{N}$ adicionado (Figura 14). Uma hipótese seria atribuir este efeito aos exsudatos radiculares quando a planta encontra-se em situação de stress.

A maior fonte de substrato para o metabolismo dos microrganismos quimiorganotróficos são os produtos da rizodeposição, que são compostos por 
exsudatos, lisados, mucilagem, secreções e células mortas, assim como gases, inclusive $\mathrm{CO}_{2}$. Dependendo da cultivar, da idade ou das condições ambientais, esta rizodeposição pode ser responsável por $40 \%$ ou mais da matéria seca produzida pela planta. $\mathrm{O}$ crescimento da microbiota é estimulado pela contínua deposição de substratos orgânicos pelas raízes, que são rapidamente assimiláveis pelos microrganismos (Lynch \& Whipps, 1990).

Possivelmente, o genótipo IAC-355 apresentou maior quantidade ou qualidade de exsudatos radiculares na ausência de $\mathrm{N}$, possibilitando maior crescimento da biomassa-C que o genótipo IAC-24. Portanto, no solo cultivado com o genótipo IAC-355, a comunidade microbiana heterotrófica foi mais eficiente em utilizar as fontes de $\mathrm{C}$ do solo, na ausência de $\mathrm{N}$ adicionado, comparando-se com o IAC-24. Quando se adicionou N, as populações microbianas atuaram sempre com a mesma taxa de respiração por unidade de biomassa- $\mathrm{C}$, indicando que a adição de 60 ou $120 \mathrm{~kg} \mathrm{ha}^{-1}$ de $\mathrm{N}$ não causou diferenças entre os genótipos avaliados.

Houve correlação entre o $\mathrm{qCO}_{2}$ e a relação Cmic:Corg (tabela 11 do anexo), indicando que realmente na ausência de fertilizante nitrogenado houve perdas de $C$ no solo cultivado com o genótipo IAC-24, enquanto que na presença do IAC-355 houve maior eficiência na utilização do $C$ do solo pelos microrganismos.

\subsubsection{Microrganismos envolvidos na ciclagem do $\mathrm{N}$ no solo.}

A análise da variância mostrou que o genótipo de trigo influenciou significativamente o número de microrganismos amonificadores no solo, independentemente da dose de $\mathrm{N}$ utilizada como adubo; e que houve interação entre genótipos e a quantidade de N, obtendo-se diferenças significativas entre os genótipos quando comparados em relação à mesma dose de $\mathrm{N}$.

O genótipo IAC-355 diferiu dos demais, havendo significativamente maior quantidade de microrganismos amonificadores no solo independente da dose de $\mathrm{N}$ adicionada (Figura 22, tabela 7 do anexo). 


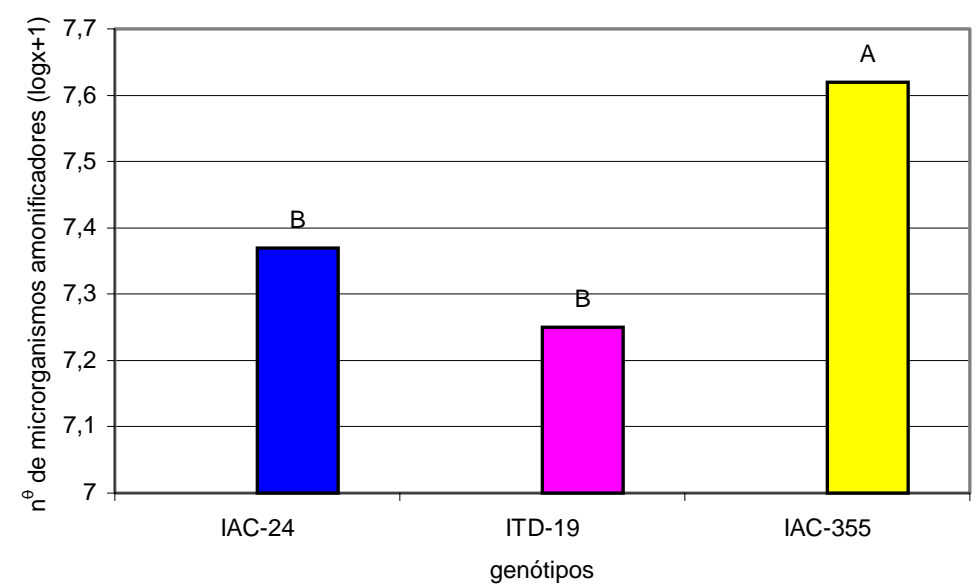

Figura 22 - Número de microrganismos amonificadores no solo empregando os genótipos de trigo IAC-24, ITD-19 e IAC-355. Letras iguais não diferem entre si pelo teste t-student a 5\%. Média de 9 repetições.

O número de microrganismos amonificadores em relação às doses de $\mathrm{N}$ adicionadas, apresentou um ajuste quadrático com ponto de mínima na dose de $53 \mathrm{Kg} \mathrm{ha}^{-1}$ de $\mathrm{N}$ para o genótipo ITD-19 e de $73 \mathrm{Kg} \mathrm{ha}^{-1}$ de $\mathrm{N}$ para o genótipo IAC-355 (Figura 23, tabela 7 do anexo).

Os genótipos se comportaram de forma diferente quando submetidos à mesma quantidade de adubo nitrogenado. $\mathrm{Na}$ ausência de $\mathrm{N}$ e presença do IAC-24 houve significativamente menor número de amonificadores no solo, enquanto que nas doses 60 e $120 \mathrm{Kg} \mathrm{ha}^{-1}$ de $\mathrm{N}$, as menores contagens ocorreram no solo sob influencia do genótipo ITD-19 (Figura 23, Tabela 7 do anexo). 


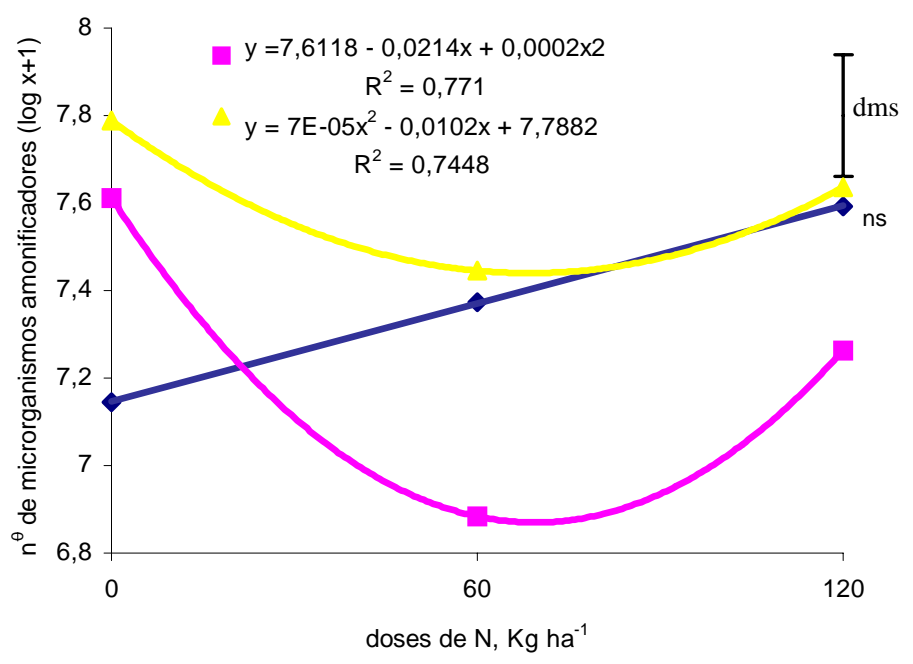

Figura 23 - Número de microrganismos amonificadores no solo em relação à dose de $\mathrm{N}$ adicionada empregando os genótipos de trigo IAC-24 (•), ITD-19 (־) e IAC-355 ( $)$ ). dmsdiferença mínima significativa pelo teste t a $5 \%$ para comparação entre genótipos em uma mesma dose de $\mathrm{N}$.

Muitos microrganismos quimiorganotróficos são responsáveis pelo processo de conversão do $\mathrm{N}$ orgânico em amônio, sendo um processo mais lento que a nitrificação. O emprego do genótipo IAC-355 acarretou maior quantidade de amonificadores no solo, provavelmente devido à influência da rizodeposição. Este mesmo genótipo apresentou maior biomassa-C na ausência de N, o que indica que os exsudatos radiculares ou a morfologia e/ou fisiologia das raízes afetaram de modo benéfico às populações de microrganismos do solo. Da mesma maneira, o emprego do genótipo IAC-24 ocasionou menor quantidade de microrganismos amonificadores, na ausência de fertilizante nitrogenado, e menor biomassa-C. Provavelmente houve uma desestimulação das populações microbianas no solo, na presença deste genótipo. Quando se adicionou N ao solo, o genótipo ITD-19 acarretou menor quantidade de microrganismos amonificadores. A liberação de exsudatos pelas 
raízes do genótipo ITD-19 pode ter influenciado na mineralização da uréia pelos microrganismos amonificadores.

Tanto para microrganismos nitritadores como para nitratadores não houve diferença significativa entre genótipos, ou seja, o genótipo da planta não interferiu no processo da nitrificação da amônia no solo (Figura 24, tabela 7 do anexo).
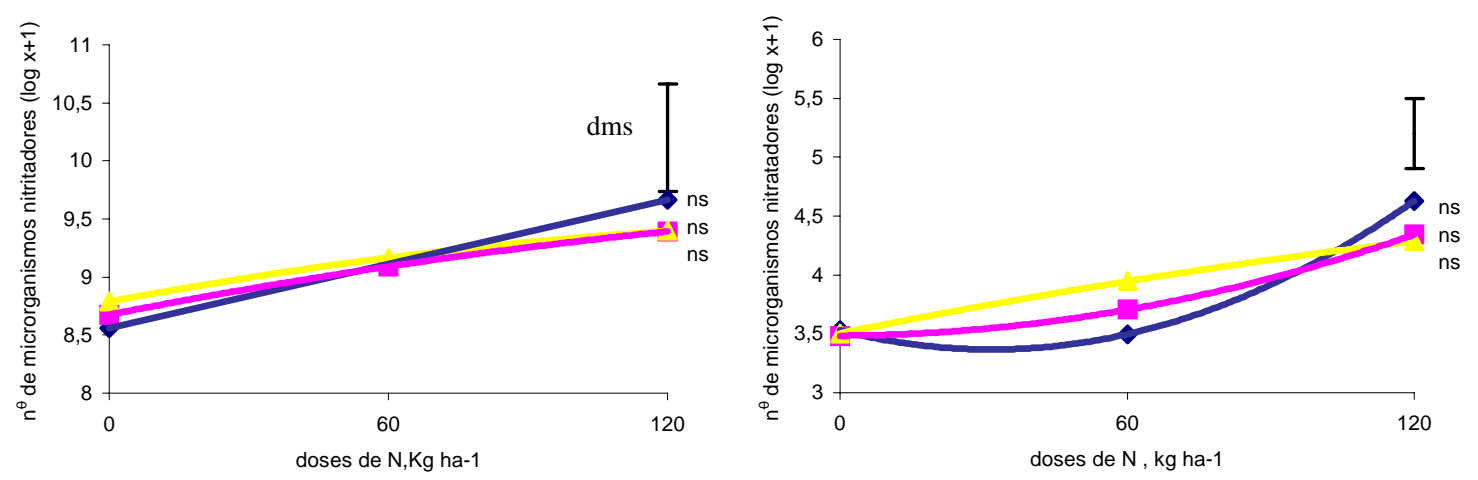

Figura 24 - Número de bactérias nitritadoras e nitratadoras no solo em relação à dose de $\mathrm{N}$ adicionada empregando os genótipos de trigo IAC-24 (•), ITD-19 ( $\bullet$ ) e IAC-355 ( $)$ ). dmsdiferença mínima significativa pelo teste t a 5\% para comparação entre genótipos em uma mesma dose de $\mathrm{N}$.

Porém houve efeito do fator doses de $\mathrm{N}$, isoladamente do genótipo da planta, ocorrendo um aumento de bactérias nitrificadoras no solo com o aumento da dose de $\mathrm{N}$ adicionada, obtendo-se um ajuste linear ascendente significativo (Figura 25, tabela 7 do anexo). 


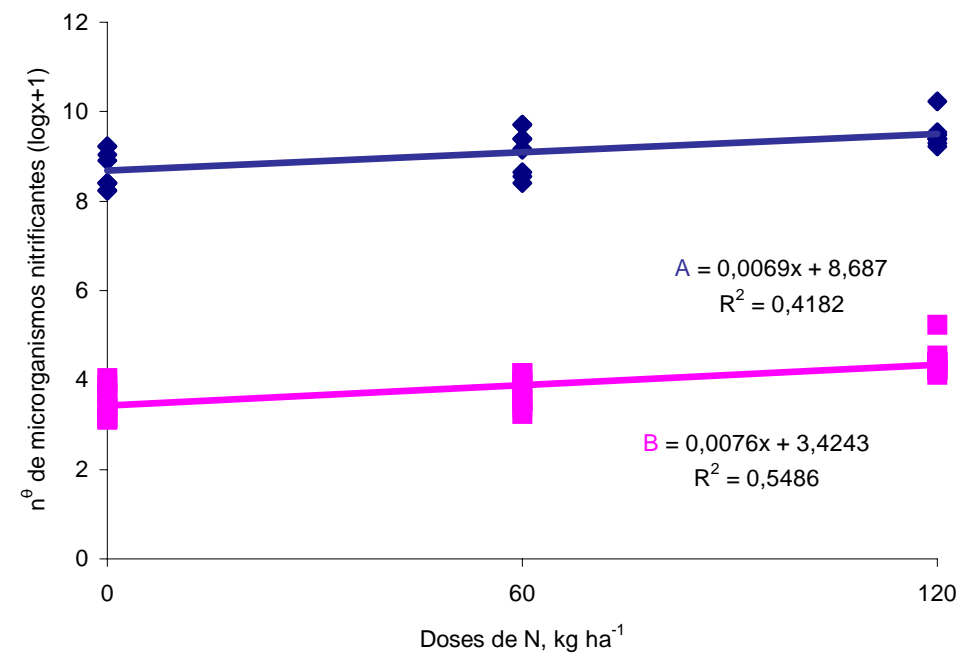

Figura 25 - (A) Quantidade de microrganismos nitritadores e (B) Quantidade de microrganismos nitratadores em relação à dose de $N$ adicionada ao solo $(n=9)$.

O processo de oxidação do amônio a nitrato é denominado nitrificação e os microrganismos responsáveis por este processo são quimiolitotróficos. São bactérias do gênero Nitrosomonas, que transformam amônia a nitrito, e Nitrobacter, que transformam nitrito a nitrato, que é a forma preferencialmente utilizada pelas plantas.

A adição de uréia provavelmente causou maior liberação de $\mathrm{NH}_{4}{ }^{+}$no solo e, portanto, maior disponibilidade de substrato para o metabolismo destes microrganismos quimiolitotróficos. Este mesmo efeito foi verificado por Lovell \& Hatch (1998), sugerindo os autores que se trataria de um efeito primário.

\subsection{Crescimento da planta}

\subsubsection{Massa da matéria seca da parte aérea.}

A análise da variância mostrou que não houve diferenças significativas entre genótipos, independente da quantidade de $\mathrm{N}$ utilizada, e que não houve interação entre os genótipos e as doses $\mathrm{N}$ avaliadas, ou seja, o genótipo não afetou a quantidade de matéria seca da parte aérea produzida pela planta 
(Figura 26, Tabela 8 do anexo). Entretanto houve efeito do fator doses de $\mathrm{N}$ isoladamente.

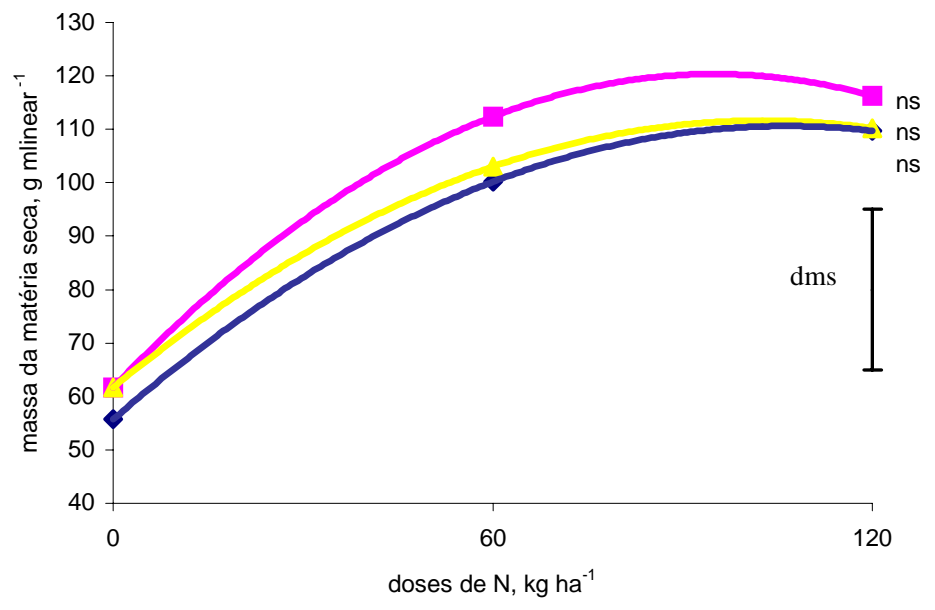

Figura 26 - Massa da matéria seca da parte aérea em relação à dose de $\mathrm{N}$ adicionada para os genótipos de trigo IAC-24 (•), ITD-19 (•) e IAC-355 ( $)$ ). dms- diferença mínima significativa pelo teste t a $5 \%$ para comparação entre genótipos em uma mesma dose de $\mathrm{N}$.

A massa da matéria seca apresentou um ajuste quadrático em relação à quantidade de adubo nitrogenado adicionado, com ponto de máxima na dose de $100 \mathrm{Kg} \mathrm{ha}^{-1}$ de N (Figura 27). 


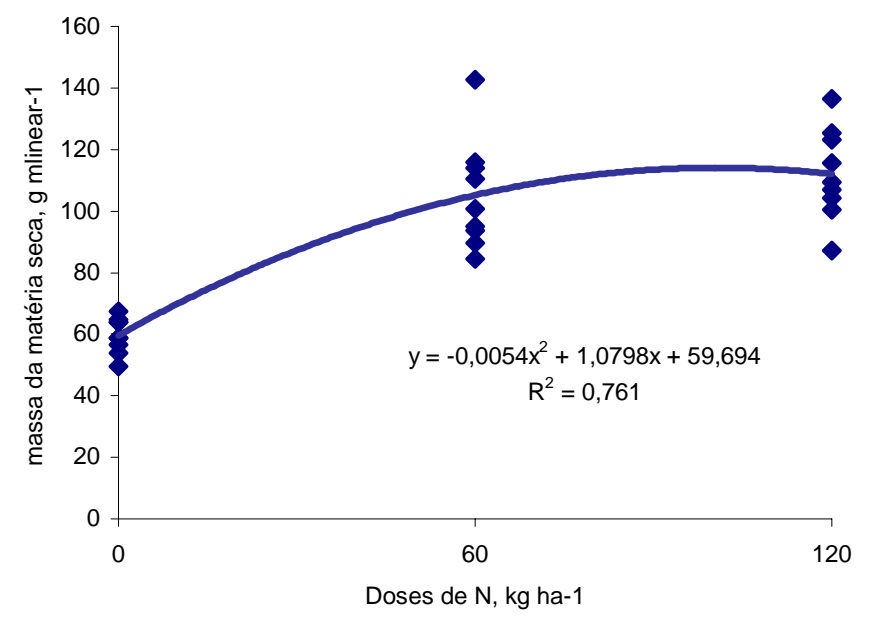

Figura 27 - Massa da matéria seca da parte aérea em relação à dose de nitrogênio adicionada ao solo em plantas de trigo $(n=9)$.

\subsubsection{Teor, quantidade acumulada e índice de eficiência de utilização do Nitrogênio e do Fósforo na parte aérea .}

A análise da variância mostrou que o teor de $\mathrm{N}$, assim como a quantidade acumulada de $\mathrm{N}$ na parte aérea de plantas de trigo, não foram influenciados pelo genótipo isoladamente, e que não houve interação entre genótipos e doses de $\mathrm{N}$ utilizadas (Figura 28, Tabela 9 do anexo), sofrendo influência apenas da quantidade de $\mathrm{N}$ adicionada como adubo. 

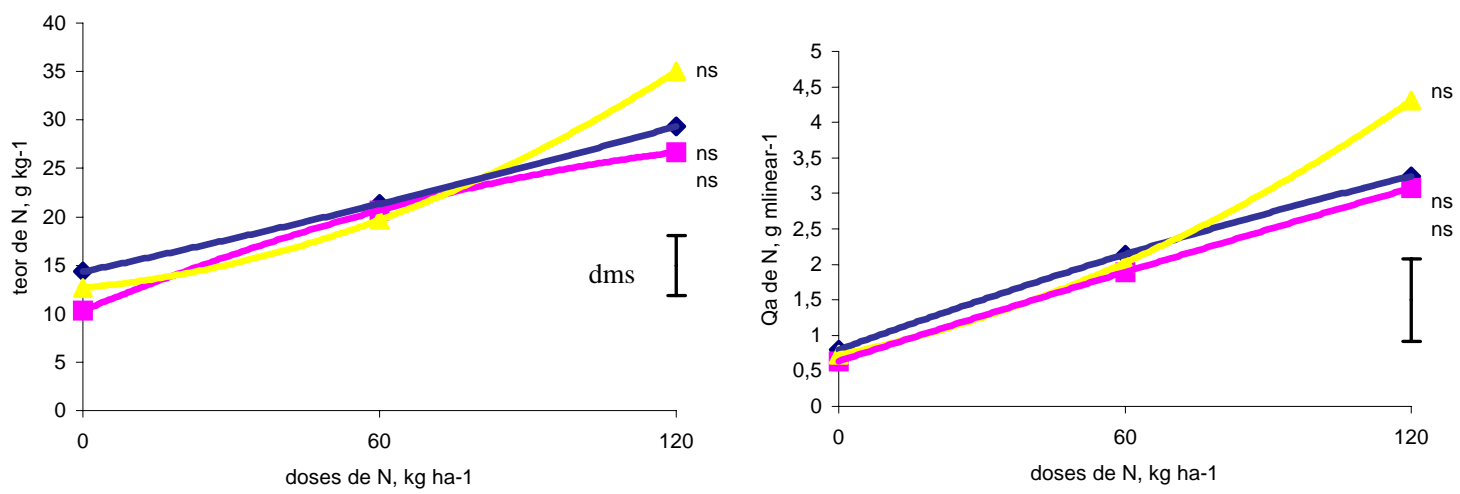

Figura 28 - Teor e quantidade acumulada de $\mathrm{N}$ na parte aérea em relação à dose de $\mathrm{N}$ adicionada para os genótipos de trigo IAC-24 (•), ITD-19 ( $\bullet$ ) e IAC-355 ( $)$ ). dms- diferença mínima significativa pelo teste t a 5\% para comparação entre genótipos em uma mesma dose de N.

Obteve-se uma regressão linear ascendente em relação à dose de $\mathrm{N}$, havendo um aumento tanto no teor quanto na quantidade acumulada de $\mathrm{N}$ com a quantidade de adubo nitrogenado utilizada (Figura 29, tabela 9 do anexo).
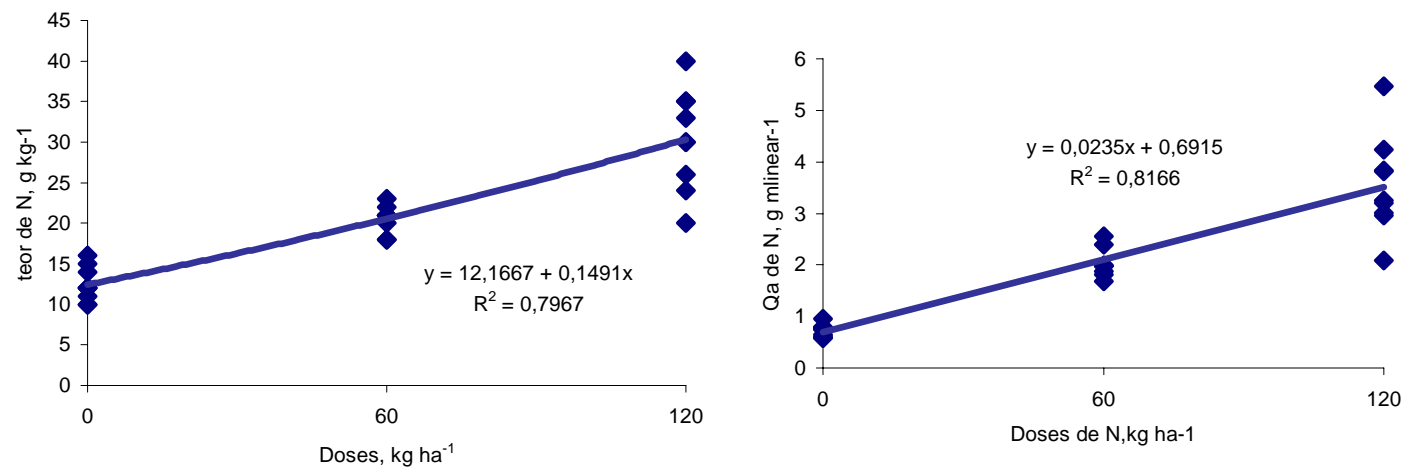

Figura 29 - Teor e quantidade acumulada de $\mathrm{N}$ na parte aérea de trigo em relação à dose de $\mathrm{N}$ adicionada ao solo $(n=9)$.

A análise da variância mostrou que o índice de eficiência de utilização do $\mathrm{N}$ foi influenciado pelo genótipo da planta, independentemente da dose de $\mathrm{N}$ 
utilizada, e que houve interação entre os genótipos e as doses de N. Observouse o efeito da quantidade de $\mathrm{N}$ adicionada excluindo-se o fator genótipo.

O genótipo ITD-19 foi a mais eficiente na utilização do $\mathrm{N}$ quando comparado aos demais, independente da quantidade de $\mathrm{N}$ utilizada (Figura 30, tabela 9 do anexo).

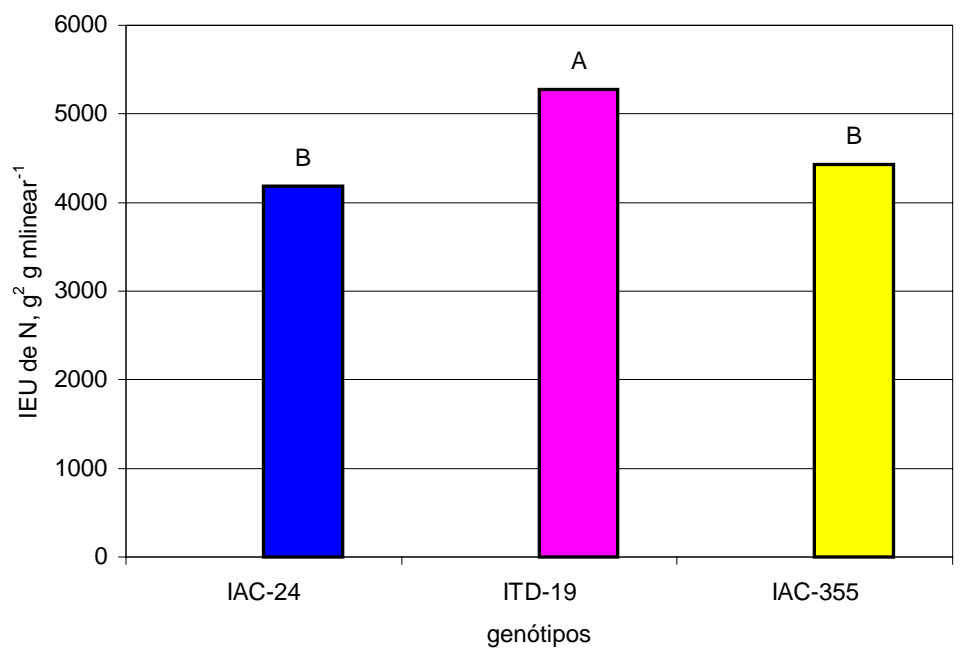

Figura 30 - Índice de eficiência de utilização do nitrogênio nos genótipos de trigo IAC-24, ITD-19 e IAC-355. Letras iguais não diferem entre si pelo teste t-student a 5\%. Média de 9 repetições.

Somente quando não foi aplicado adubo nitrogenado observou-se diferença significativa entre os genótipos avaliados, sendo que o genótipo ITD19 apresentou significativamente maior IEU do N que o genótipo IAC-24 o qual diferiu significativamente dos demais genótipos (Figura 31, tabela 9 do anexo). 


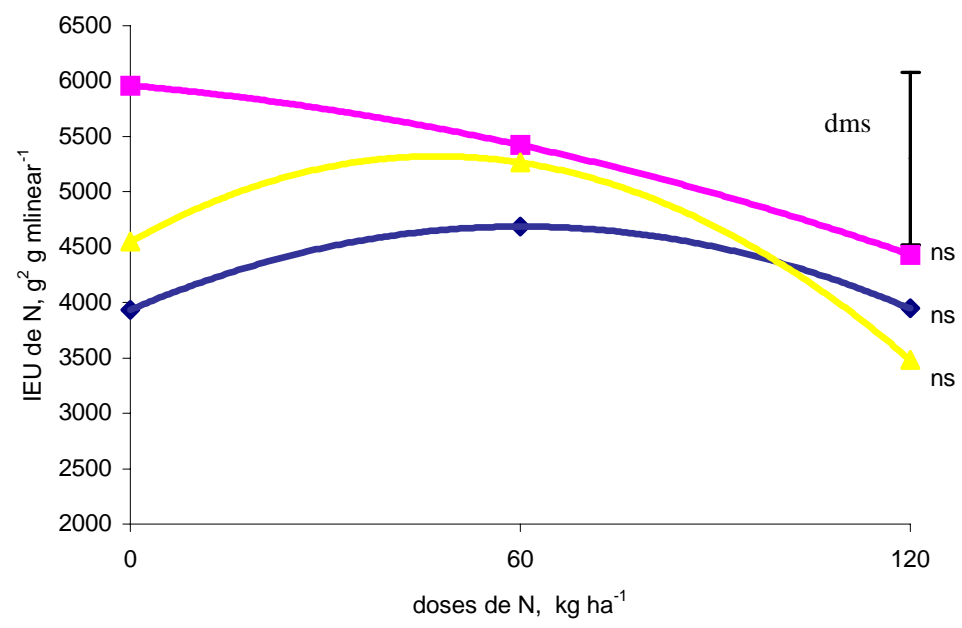

Figura 31 - IEU de N em relação à dose de $\mathrm{N}$ adicionada, para os genótipos de trigo IAC-24 (•), ITD-19 ( $\square$ ) e IAC-355 ( $)$ ). dms- diferença mínima significativa pelo teste $\mathrm{t}$ a $5 \%$ para comparação entre genótipos em uma mesma dose de N.

O índice de eficiência de utilização pode não corresponder à realidade para cultura do trigo, devido à amostragem ter sido feita somente no início do florescimento. Para maior fidedignidade dos resultados, deveriam ter sido feitas outras amostragens. Pois muitas vezes a planta pode ter absorvido o nutriente, mais ainda não ter convertido em massa celular.

$O$ genótipo da planta não influenciou $O$ teor de $P$, a quantidade acumulada e ou o índice de eficiência de utilização deste nutriente (Figura 32, Tabela 10 do anexo). Entretanto observou-se efeito da quantidade de $\mathrm{N}$, quando se avaliou o fator doses isoladamente do genótipo. 

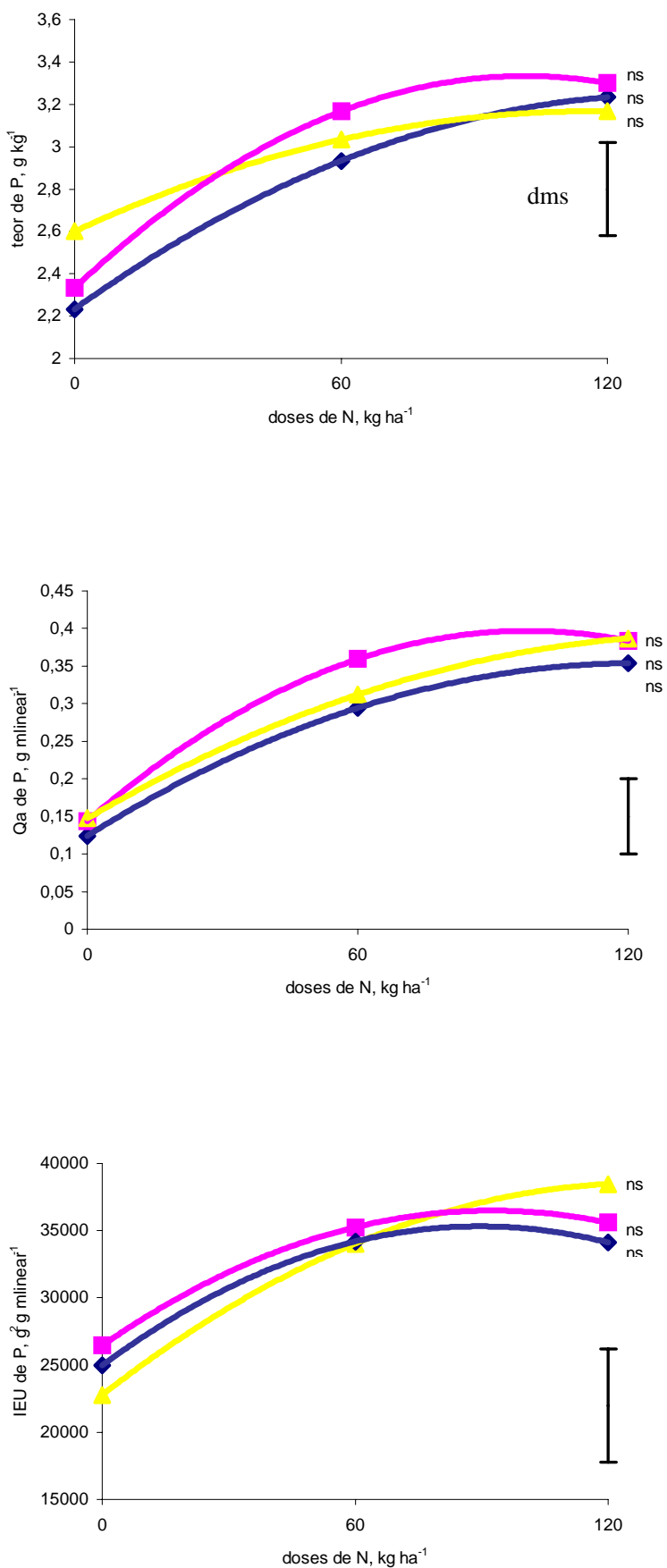

Figura 32 - Teor e quantidade acumulada de $P$ na parte aérea, e índice de eficiência de utilização do $\mathrm{P}$ em relação à dose de $\mathrm{N}$ adicionada para os genótipos de trigo IAC-24 (४), ITD-

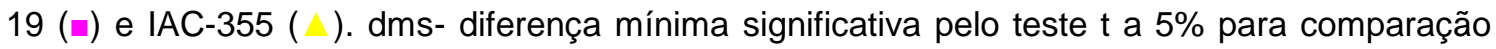
entre genótipos em uma mesma dose de $\mathrm{N}$. 
$\mathrm{O}$ teor de $\mathrm{P}$ em relação à dose de $\mathrm{N}$ adicionada apresentou um ajuste quadrático com ponto de máxima na dose de $115 \mathrm{~kg} \mathrm{ha}^{-1}$ de $\mathrm{N}$ (Figura 33, tabela 10 do anexo).

A quantidade acumulada de $\mathrm{P}$ e o índice de eficiência de utilização do $\mathrm{P}$ em relação à quantidade de $\mathrm{N}$ utilizada apresentaram um ajuste quadrático com ponto de máxima em torno de $100 \mathrm{~kg} \mathrm{ha}^{-1}$ de $\mathrm{N}$ (Figura 33, tabela 10 do anexo). 

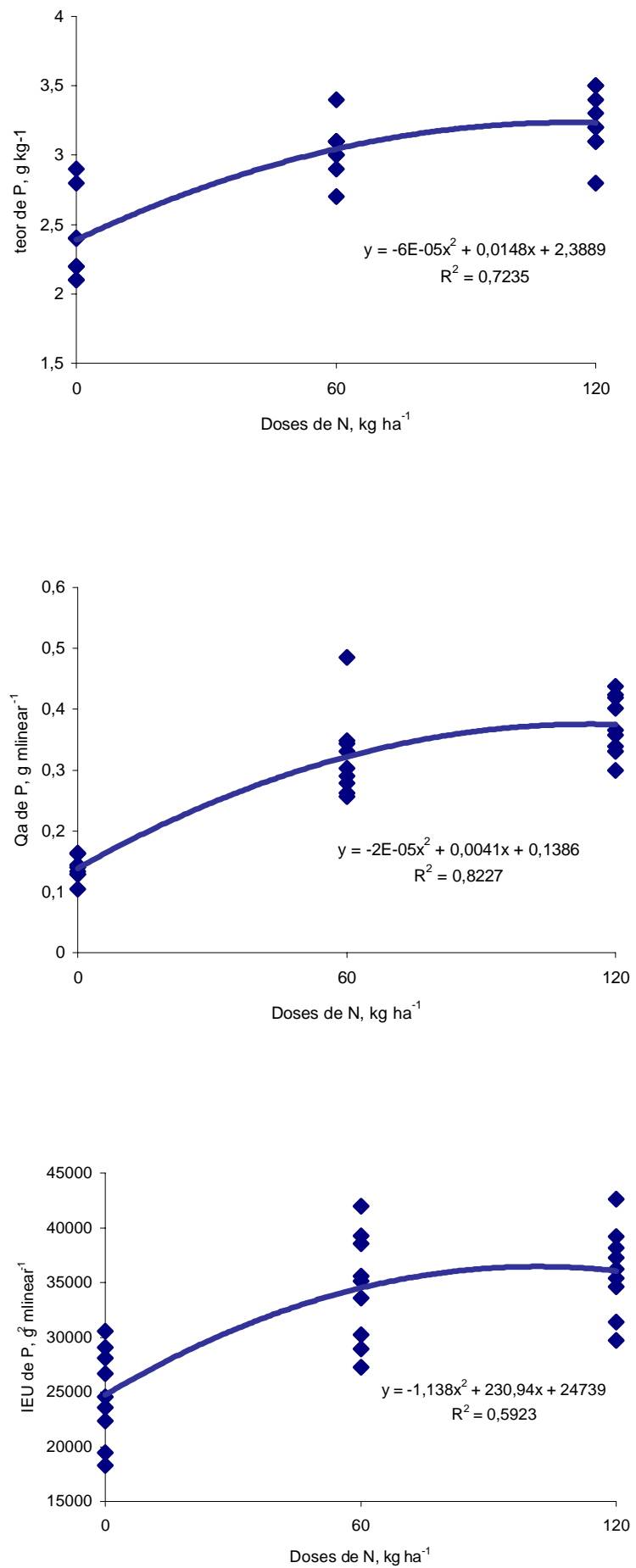

Figura 33 - Teor, quantidade acumulada de P na parte aérea, e índice de eficiência de utilização do $P$ em relação à dose de $N$ adicionada ao solo em plantas de trigo $(n=9)$. 
$\mathrm{O}$ teor e a quantidade acumulada de $\mathrm{N}$ se correlacionaram com a colonização micorrízica (tabela 12 do anexo). Foi estimado que o fluxo de $\mathrm{N}$ é três vezes maior em plantas micorrizadas que em plantas não micorrizadas e que a colonização aumenta a quantidade de $\mathrm{N}$ na planta, mas a eficiência de utilização depende do fungo envolvido (Vázquez et al., 2001).

A colonização micorrízica se correlacionou com teor, quantidade acumulada e com o índice de eficiência de utilização do fósforo da parte aérea do trigo (tabela 12 do anexo). Este resultado confirma que a planta quando colonizada por FMAs tem seu potencial de aquisição de $\mathrm{P}$ aumentado.

\subsubsection{Produtividade}

Através da análise da variância observou-se que houve efeito do genótipo da planta isoladamente sobre a produção de grãos e das doses de $\mathrm{N}$ adicionadas. Houve interação entre os genótipos e a quantidade de adubo nitrogenado. No genótipo IAC-355 obteve-se significativamente maior produção de grãos em relação aos demais genótipos, independentemente da quantidade de $\mathrm{N}$ adicionada (Figura 34, tabela 8 do anexo).

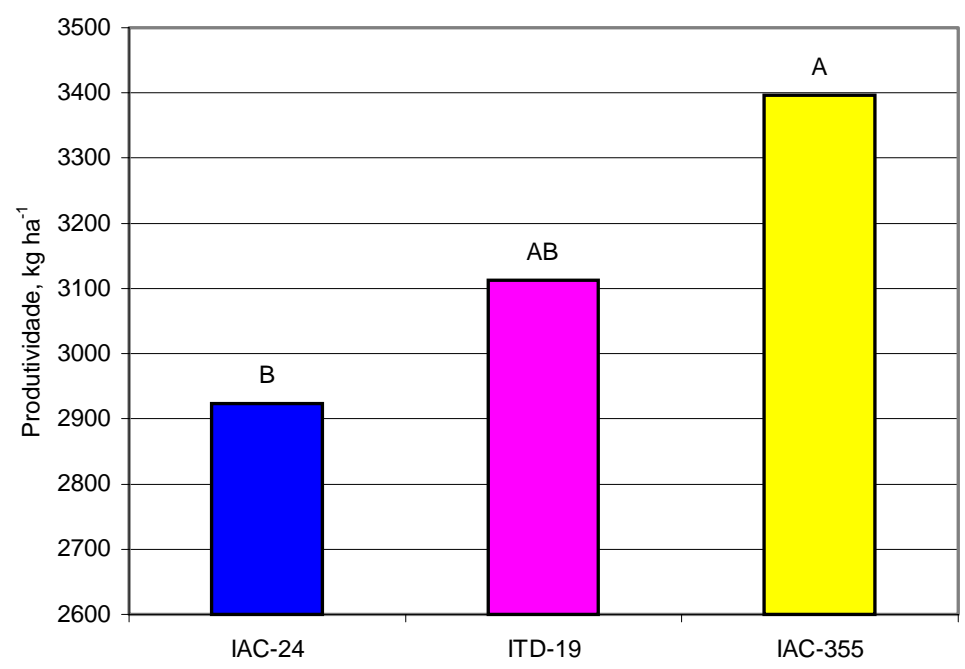

Figura 34 - Produtividade dos genótipos de trigo IAC-24, ITD-19 e IAC-355. Letras iguais não diferem entre si pelo teste t-student a 5\%. Média de 9 repetições. 
A resposta dos genótipos ao aumento da dose de $\mathrm{N}$ adicionada mostrou ajuste quadrático com ponto de máxima em torno de $110 \mathrm{~kg} \mathrm{ha}^{-1}$ de $\mathrm{N}$ para todos os genótipos avaliados (Figura 35, tabela 8 do anexo).

Quando se comparou o comportamento das variedades em relação à mesma quantidade de $\mathrm{N}$ adicionada, observou-se que não houve diferença significativa entre os genótipos quando não foi aplicado adubo nitrogenado, e que na dose 60 e $120 \mathrm{~kg} \mathrm{ha}^{-1}$ de $\mathrm{N}$ o genótipo IAC-24 foi menos produtivo que os demais genótipos (Figura 35, Tabela 8 do anexo). Isto sugere que o genótipo IAC-24 é menos responsivo ao $\mathrm{N}$ que os demais cultivares.

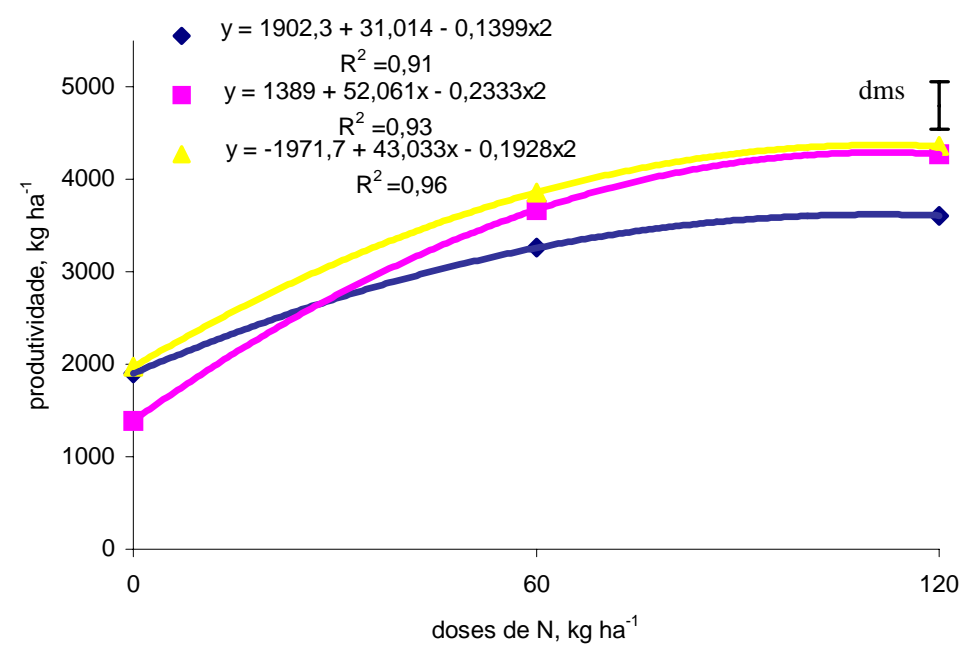

Figura 35 - Produtividade em relação à dose de $\mathrm{N}$ adicionada para os genótipos de trigo IAC-24 $(\diamond)$, ITD-19 ( $\square$ ) e IAC-355 ( $)$. dms- diferença mínima significativa pelo teste $\mathrm{t}$ a $5 \%$ para comparação entre cultivares em uma mesma dose de $\mathrm{N}$.

Quando foi observado o efeito da quantidade de $\mathrm{N}$ adicionada independentemente do genótipo utilizado, obteve-se um ajuste quadrático com ponto de máxima na dose de $110 \mathrm{~kg} \mathrm{ha}^{-1}$ de $\mathrm{N}$, ou seja, a produtividade máxima foi obtida com a adição de $110 \mathrm{~kg} \mathrm{ha}^{-1}$ de $\mathrm{N}$ (Figura 36, tabela 8 do anexo), dose na qual se obteve também o máximo de produção de matéria seca da parte aérea (Figura 27). 


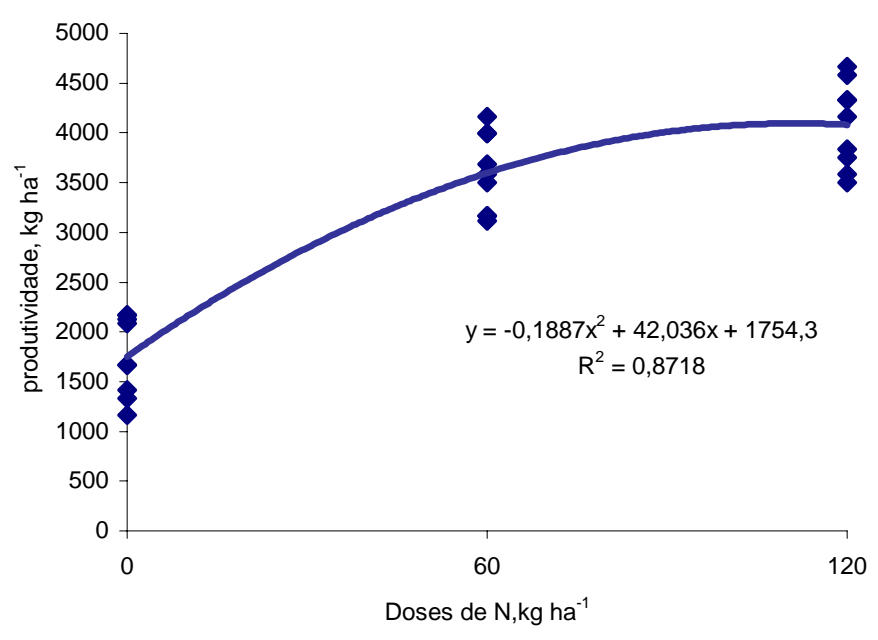

Figura 36 - Produtividade de trigo em relação à dose de $N$ adicionada ao solo $(n=9)$.

A quantidade de $110 \mathrm{~kg} \mathrm{ha}^{-1}$ está de acordo com as recomendações de adubação nitrogenada para o trigo irrigado no estado de São Paulo. Segundo Raij et al., a recomendação é de 20 a $30 \mathrm{~kg} \mathrm{ha}^{-1}$ de $\mathrm{N}$ no plantio e de 60 a $90 \mathrm{~kg}$ $\mathrm{ha}^{-1}$ de $\mathrm{N}$ em cobertura para uma alta produtividade.

Os genótipos empregados comportaram-se de maneira diferente quanto à adubação nitrogenada (Figura 37), como já demonstrado por Freitas et al. (1995) para o genótipo IAC-24, que é um cultivar comercialmente lançado, e para os outros genótipos ainda em fase de pesquisa (Freitas, comunicação pessoal).

$\mathrm{Na}$ ausência de fertilizante nitrogenado o genótipo IAC-24 e IAC-355 foram eficientes, ou seja, apresentaram maior produção de grãos que a média da população (genótipos utilizados). Entretanto, o genótipo ITD-19 foi ineficiente em produzir grãos na ausência de $\mathrm{N}$, em relação aos demais genótipos. Quando aplicado N ao solo o genótipo IAC-24 foi considerado não responsivo, pois sua produtividade aumentou menos em função do $\mathrm{N}$ adicionado, que a produtividade dos demais genótipos empregados. 


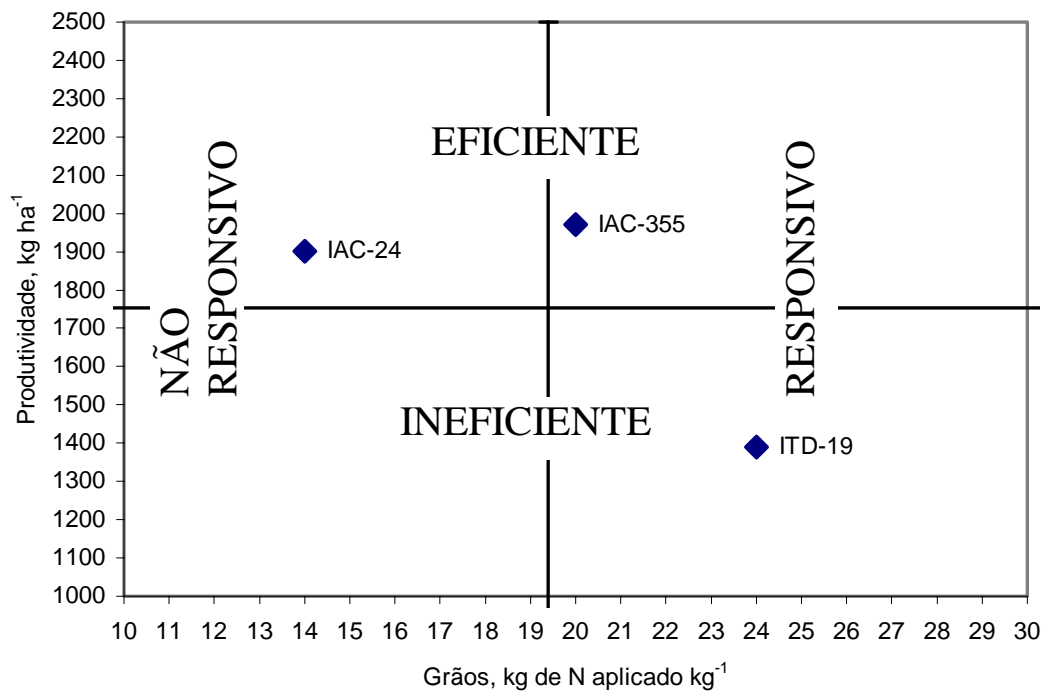

Figura 37 - Médias da produção de grãos na dose $0 \mathrm{~kg} \mathrm{ha}^{-1}$ de $\mathrm{N}$ dos genótipos IAC-24, ITD-19 e IAC-355 (eixo x), e a diferença entre a média da produção de grãos na dose $120 \mathrm{~kg} \mathrm{ha}^{-1}$ e na dose $0 \mathrm{~kg} \mathrm{ha}^{-1}$ de $\mathrm{N}$ dividida por 120 (Seetharama et al., 1990).

A quantidade de microrganismos nitrificadores se correlacionou com o teor e com a quantidade acumulada de $\mathrm{N}$ na parte aérea, assim como, com a massa da matéria seca da parte aérea e com a produtividade (tabela 12 do anexo). Provavelmente, com a maior disponibilidade de nitrato $\left(\mathrm{NO}_{3}\right)$, propiciada pelos microrganismos nitrificadores, a planta pode absorver mais nitrogênio e converter em matéria seca e produção de grãos.

A colonização micorrízica se correlacionou com a massa da matéria seca da parte aérea e com a produtividade (tabela 12 do anexo). Provavelmente devido a maior absorção de nutrientes pela planta propiciada pela micorriza.

\subsubsection{Teor de $\mathbf{N}$ no grão}

Através da análise da variância observou-se que não houve diferenças significativas no teor de $\mathrm{N}$ no grão entre os genótipos avaliados, ou seja, não houve influencia do genótipo da planta. Entretanto, houve efeito da quantidade 
de $\mathrm{N}$ utilizada como adubo independentemente do genótipo de trigo (Figura 38, tabela 11 do anexo).

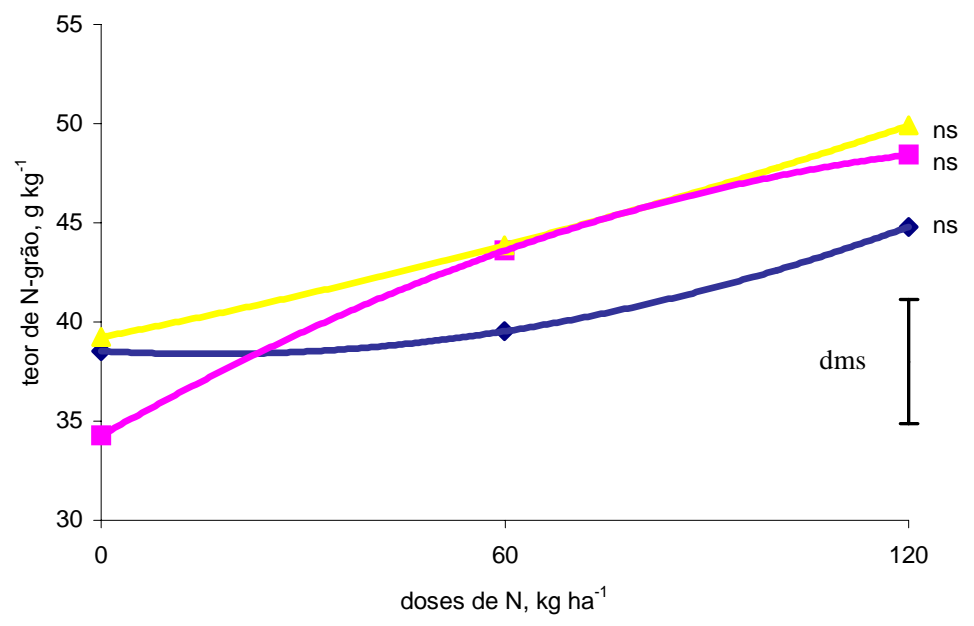

Figura 38 - Teor de $\mathrm{N}$ no grão em relação à dose de $\mathrm{N}$ adicionada para os genótipos de trigo IAC-24 (•), ITD-19 ( $₫)$ e IAC-355 ( $)$ ). dms- diferença mínima significativa pelo teste t a 5\% para comparação entre genótipos em uma mesma dose de $\mathrm{N}$.

Quando se observou o fator doses isoladamente, obteve-se uma regressão linear ascendente em relação à dose de $\mathrm{N}$, ou seja houve aumento no teor de $\mathrm{N}$ no grão com a dose de $\mathrm{N}$ adicionada (Figura 39, tabela 11 do anexo). 


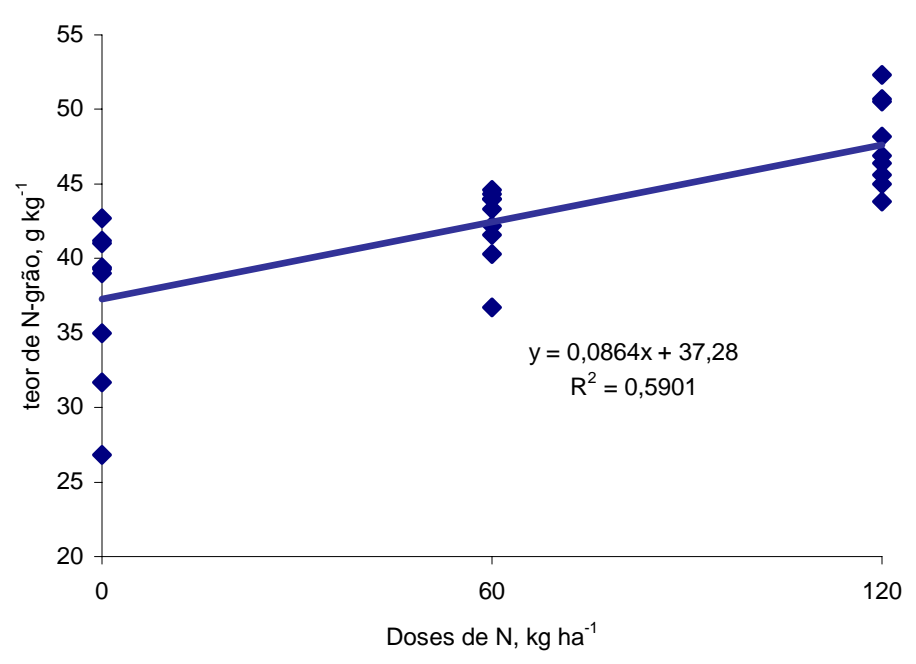

Figura 39 - Teor de $N$ no grão de trigo em relação à dose de $N$ adicionada ao solo $(n=9)$.

\subsection{Interação de fungos micorrízicos arbusculares e bactérias diazotróficas endofíticas.}

\subsubsection{Quantificação de bactérias diazotróficas endofíticas}

O fungo micorrízico influenciou a quantidade de bactérias diazotróficas endofíticas nas raízes do trigo. Nos tratamentos em que a bactéria e o fungo micorrízico foram inoculados conjuntamente, na presença do fungo do gênero Acaullospora houve aumento na quantidade de bactérias. Também nos tratamentos que receberam somente FMAs, obteve-se o mesmo efeito quando comparado ao tratamento com FMA do gênero Glomus sp (Tabelas 4 e 5).

Vários autores já demonstraram a ocorrência de bactérias diazotróficas endofíticas na superfície e dentro de esporos de FMAs (Mosse , 1962; Varma et al., 1981, Paula et al., 1990, 1991, 1993). Tilak et al. (1989) sugerem que as bactérias diazotróficas podem contribuir para nutrição dos FMAs, disponibilizando N. Os mesmos autores isolaram Azospirillum spp. da superfície de diferentes espécies de FMAs, 3 de Glomus spp e 1 de. Gigaspora sp. 
A ocorrência de bactérias diazotróficas endofíticas dentro ou na superfície de esporos de FMAs está relacionada à espécie do fungo, a planta hospedeira e ainda ao substrato utilizado. Paula et al. (1991) observaram que esporos de Glomus clarum isolados de Brachiaria sp. em solo esterilizado não continham diazotróficos em sua superfície ou internamente. Mas esporos de $G$. occultum e de Acaullospora sp., coletados no campo de plantas de batata doce que não haviam recebido inóculo de bactéria diazotrófica, continham Gluconacetobacter diazotrophicus (Paula et al., 1990). Entretanto Reis et al. (1999) não obtiveram o mesmo resultado utilizando plantas de cana-de-açúcar, concluindo que Gluconacetobacter diazotrophicus não está associada a esporos de FMAs nativos desinfestados superficialmente, somente está presente em esporos nativos lavados com água esterilizada. Paula et al. (1993) isolaram $G$. diazotrophicus, A. lipoferum e Klebisiela spp de esporos nativos desinfestados superficialmente ou lavados com água esterilizada utilizando plantas de batata-doce.

Obteve-se maior colonização radicular quando foi utilizado o isolado 3, nos tratamentos com bactéria diazotrófica endofítica isoladamente. Entretanto, quando o fungo micorrízico estava presente, não houve efeito dos isolados utilizados na colonização radicular (Tabelas 4 e 5).

Quando se avaliou a colonização nos tratamentos que bactéria e fungo micorrízico foram inoculados conjuntamente em comparação com os tratamentos que receberam o FMA ou a bactéria isoladamente, observou-se que a colonização foi maior quando as bactérias foram inoculadas isoladamente e menor quando se utilizou somente o FMA.

Em plantas de sorgo obteve-se maior colonização por Azospirillum sp., quando G. etunicatum e Azospirillum sp. foram co-inoculados em comparação com a bactéria sozinha (Pacovsky, 1989). Paula et al. (1991) obtiveram o mesmo efeito em plantas de batata doce infectadas por $G$. clarum e $G$. diazotrophicus. Já Isopi et al. (1995) observaram em plantas de sorgo colonizadas por $G$. diazotrophicus e 4 diferentes espécies de FMAs, que a 
quantidade de bactérias variou em função do fungo envolvido na associação, o que ocorreu no presente experimento, mas envolvendo Herbaspirillum sp.

Somente houve efeito sinérgico dos FMAs e das bactérias diazotróficas na colonização radicular de plantas de trigo na presença do Acaullospora sp. e do isolado 7 , porém não foi estatisticamente significativo. Possivelmente houve competição entre os microsimbiontes pois a planta estava em substrato sem $\mathrm{N}$, resultando na diminuição da colonização pelas bactérias diazotróficas endofíticas quando o FMA foi co-inoculado.

Tabela 4. Quantificação de bactérias diazotróficas endofíticas em meio JNFb, nas raízes de trigo. Média de 5 repetições.

\begin{tabular}{cc}
\hline TRATAMENTOS & $\begin{array}{c}\text { Contagem de bactérias diazotróficas } \\
\mathrm{n}^{\theta} \\
10^{6} \mathrm{~g}^{-1} \text { raiz }\end{array}$ \\
\hline B1 & 3,3 \\
B1F1 & 0,61 \\
B1F2 & 3,7 \\
B2 & 1,16 \\
B2F1 & 0,44 \\
B2F2 & 4,19 \\
F1 & 0,26 \\
F2 & 0,65 \\
\hline
\end{tabular}

B1: isolado 3, IAC-HT-12, B2: isolado 7, IAC-HT-11, F1: Glomus sp, F2: Acaullospora sp 
Tabela 5. Teste F para comparação dos contrastes ortogonais obtidos entre os tratamentos para a quantificação de bactérias diazotróficas endofíticas na raiz (dados transformados $\log x+1$ ).

\begin{tabular}{lcl}
\hline Contrastes ortogonais & $\begin{array}{c}\text { Colonização } \\
\text { bactérias diazotróficas }\end{array}$ \\
\hline G.L.=1 e 32 & $F$ & \\
$F_{0}=4,15 P\left(F>F_{0}\right)=5 \%$ & 4,29 & $*$ \\
BF-B & 55,43 & $*$ \\
BF1-BF2 & 2,50 & ns \\
B1F-B2F & 17,35 & $*$ \\
BF-F & 5,25 & $*$ \\
F1-F2 & 6,29 & $*$ \\
B1-B2 & *
\end{tabular}

B1: isolado 3, IAC-HT-12, B2: isolado 7, IAC-HT-11, F1: Glomus sp, F2: Acaullospora sp.

\subsubsection{Colonização micorrízica.}

A bactéria diazotrófica influenciou a colonização micorrízica nos tratamentos em que a bactéria e o fungo foram co-inoculados, na presença do isolado 7 obteve-se maior colonização micorrízica, independentemente do FMA utilizado (Tabelas 6 e 7). Provavelmente houve uma estreita relação FMA e bactéria, onde dependendo da bactéria envolvida a colonização micorrízica foi afeta ou não.

Biró et al. (2000) utilizaram $G$. fasciculatum em combinação com $A$. brasilense ou $R$. meliloti, ou os três inóculos conjuntamente, em plantas de alfafa e diferentes substratos, mas contento $\mathrm{N}$ e P. Em solo esterilizado a colonização micorrízica variou entre as bactérias utilizadas na associação, demonstrando a especificidade da interação fungo-planta-bactéria.

Os FMAs utilizados não diferiram entre si quanto à colonização radicular, quando os tratamentos que receberam somente FMA foram comparados, e também quando comparou-se os tratamentos que receberam ambos os inóculos. 
Quando se avaliou a colonização nos tratamentos que bactéria e fungo micorrízico foram inoculados conjuntamente em comparação com os tratamentos que receberam o FMA ou a bactéria isoladamente, observou-se que a colonização foi maior quando somente os FMAs estavam presentes. Possivelmente houve competição entre FMAs e bactérias na colonização das raízes, não havendo um efeito sinérgico na colonização micorrízica, mas ao contrário, uma diminuição significativa na colonização micorrízica na presença do isolado 3 (Tabelas 6 e 7).

Em raízes de cereais infectadas com Azospirillum ssp. e FMAs, ambos endofíticos estão presentes na mesma área cortical das raízes. Isto torna possível que haja uma interação direta entre planta-bactéria-FMA, o que pode resultar em competição por fotossintetisados (Pacovsky \& Fuller, 1984).

Outra hipótese seria atribuir este efeito a diferença na solução nutritiva, pois os tratamentos que bactéria e fungo foram co-inoculados não receberam $\mathrm{N}$ e os tratamentos com FMA sozinho receberam $\mathrm{N}$, mas ambos receberam a mesma quantidade de P. A planta bem nutrida teve mais condições no estabelecimento da colonização por FMAs, suportando o alto custo energético envolvido na simbiose, uma vez que os mecanismos de regulação da colonização são funcionalmente dependentes do carbono disponível para o fungo durante a colonização. 
Tabela 6. Quantificação da colonização micorrízica nas raízes de trigo. Média de 5 repetições.

\begin{tabular}{cc}
\hline & FMA \\
TRATAMENTOS & \% de colonização \\
\hline B1F1 & 26,8 \\
B1F2 & 29,2 \\
B2F1 & 33,25 \\
B2F2 & 33 \\
F1 & 39,8 \\
F2 & 38 \\
\hline
\end{tabular}

B1: isolado 3, IAC-HT-12, B2: isolado 7, IAC-HT-11, F1: Glomus sp, F2: Acaullospora sp

Tabela 7. Teste $F$ para comparação dos contrastes ortogonais obtidos entre os tratamentos para a quantificação de fungos micorrízicos na raiz (dados transformados arcsen $\sqrt{ } \mathrm{x} / 100$ ).

\begin{tabular}{lcl}
\hline Contrastes ortogonais & $\begin{array}{c}\text { Colonização } \\
\text { FMAs }\end{array}$ \\
\hline G.L. $=1$ e 23 & $F$ & \\
$F_{0}=4,28 \quad P\left(F>F_{0}\right)=5 \%$ & 1,55 & $n s$ \\
BF1-BF2 & 30,62 & $*$ \\
B1F-B2F & 103,22 & $*$ \\
BF-F & 1,79 & ns \\
F1-F2 &
\end{tabular}

B1: isolado 3, IAC-HT-12, B2: isolado 7, IAC-HT-11, F1: Glomus sp, F2: Acaullospora sp

\subsubsection{Massa da matéria fresca da raiz}

A bactéria diazotrófica utilizada influenciou a massa da matéria fresca das raízes nos tratamentos em que a bactéria e o fungo micorrízico foram coinoculados. Nas plantas em que a bactéria diazotrófica 3 foi inoculada obtevese maior peso das raízes que nas plantas que receberam a bactéria 7, entretanto não houve diferenças entre os tratamentos que receberam bactéria diazotrófica isoladamente (Tabelas 8 e 9). 
O fungo micorrízico utilizado influenciou a massa da matéria fresca das raízes nos tratamentos em que a bactéria e fungo micorrízico foram coinoculados, nos tratamentos com FMA do gênero Glomus obteve-se maior peso das raízes que nos tratamentos com o gênero Acaullospora. Entretanto, na presença do isolado 7, as plantas colonizadas por Glomus não diferiram das colonizadas por Acaullospora. Também não houve diferenças entre os tratamentos que continham somente FMAs, demonstrando que houve interação entre os FMAs e pelo menos uma das bactérias diazotróficas utilizadas. O nível de $\mathrm{N}$ na solução nutritiva parece ter influenciado o comportamento dos microrganismos, pois houve diferenças entre os tratamentos na ausência de $\mathrm{N}$, mas quando se adicionou $\mathrm{N}$ não pode ser observado influencia dos FMAs utilizados.

Vázquez et al. (2000) observaram o efeito da co-inoculação de Azospirillum sp. com 2 espécies diferentes de FMAs ou com solo contendo a comunidade natural de FMAs, sobre a produção de matéria seca de milho, e obtiveram efeito positivo apenas com uma espécie de FMA utilizado na interação. Isopi et al. (1995) estudando a interação entre G. diazotrophicus e diversos FMAs em sorgo, também demonstraram que o efeito benéfico sobre a produção de matéria seca depende do fungo envolvido na associação.

Quando se avaliou a massa da matéria fresca da raiz nos tratamentos que bactéria e fungo micorrízico foram co-inoculados em comparação com os tratamentos que receberam o FMA ou a bactéria isoladamente, observou-se que o peso da raiz foi maior quando somente os FMAs ou as bactérias estavam presentes. Provavelmente, houve competição por fotossintetisados entre FMAs e bactérias, não havendo um efeito sinérgico no desenvolvimento das raízes.

Os FMAs isoladamente não influenciaram a massa da matéria fresca das raízes quando comparados à testemunha que não continha FMA e bactéria e que recebeu a mesma solução nutritiva (T-P). Este fato pode estar relacionado a influencia da solução nutritiva sobre um possível efeito do FMA, ou seja, a 
quantidade de $\mathrm{P}$ utilizada pode não ter sido adequada para se obter resposta da inoculação do FMA.

A bactéria influenciou positivamente o desenvolvimento das raízes nos tratamentos que continham bactéria diazotrófica isoladamente quando comparado à testemunha (T-N). Entretanto, quando as bactérias e os FMAs foram co-inoculados, o peso da raiz não foi alterado, comparando estes tratamentos com a testemunha sem bactéria e FMA e que recebeu a mesma solução nutritiva (T-N). O FMA afetou negativamente o desenvolvimento das raízes propiciado pelas bactérias diazotróficas endofíticas.

Nos tratamentos com bactérias diazotróficas sozinhas obteve-se 2 vezes mais massa de matéria fresca da raiz que na testemunha (T-N). Já foram observados vários efeitos na morfologia das raízes infectadas por bactérias diazotróficas endofíticas, como aumento no comprimento da raiz, aumento no número de ramificações e aumento da superfície radicular e ainda aumento de pêlos radiculares (Martin et al., 1989; Dobbelaere et al., 1999).

A testemunha que recebeu solução nutritiva completa $(T+N)$ superou todos os demais tratamentos, quando se avaliou a massa da matéria fresca das raízes. 
Tabela 8. Massa da matéria fresca da raiz. Média de 5 repetições.

\begin{tabular}{cc}
\hline TRATAMENTOS & Massa da matéria fresca raiz, g planta ${ }^{-1}$ \\
\hline B1 & 6,82 \\
B1F1 & 5,16 \\
B1F2 & 2,44 \\
B2 & 6,87 \\
B2F1 & 1,88 \\
B2F2 & 1,88 \\
F1 & 6,74 \\
F2 & 7,06 \\
T+N & 10,88 \\
T-N & 3,3 \\
T-P & 7,46
\end{tabular}

B1: isolado 3, IAC-HT-12, B2: isolado 7, IAC-HT-11, F1: Glomus sp., F2: Acaullospora sp., T+N: testemunha que recebeu solução nutritiva completa, T-N: testemunha que recebeu metade da quantidade de $\mathrm{P}$ da solução completa e não recebeu N, T-P: testemunha que recebeu metade da quantidade de $\mathrm{P}$ da solução completa. 
Tabela 9. Teste F para comparação dos contrastes ortogonais obtidos entre os tratamentos para quantificação da massa da matéria fresca das raízes.

\begin{tabular}{|c|c|c|}
\hline Contrastes ortogonais & \multicolumn{2}{|l|}{ fresca raiz } \\
\hline \multicolumn{3}{|l|}{ G.L. $=1 \mathrm{e} 41$} \\
\hline$F_{0}=4,08 P\left(F>F_{0}\right)=5 \%$ & $\mathrm{~F}$ & \\
\hline BF-F & 223,36 & * \\
\hline BF-B & 217,45 & * \\
\hline BF1-BF2 & 18,80 & * \\
\hline B1F-B2F & 37,46 & * \\
\hline F- T-P & 2,12 & ns \\
\hline B - T-N & 85,00 & * \\
\hline BF-T-N & 1,75 & ns \\
\hline B-F & 0,03 & ns \\
\hline $\mathrm{F} 1-\mathrm{F} 2$ & 0,52 & ns \\
\hline B1-B2 & 0,01 & ns \\
\hline B1F1-BIF2 & 37,59 & * \\
\hline B1F1-BF & 72,93 & * \\
\hline B2FI-B2F2 & 0 & ns \\
\hline
\end{tabular}

\subsubsection{Massa da matéria seca da parte aérea.}

A bactéria diazotrófica não influenciou o peso da parte aérea nos tratamentos em que a bactéria e o fungo micorrízico foram co-inoculados, e também, nos tratamentos que receberam bactérias isoladamente (Tabelas $10 \mathrm{e}$ 11). Já o fungo micorrízico influenciou o peso da parte aérea nos tratamentos em que a bactéria e fungo micorrízico foram inoculados conjuntamente, pois nas plantas colonizadas por Glomus houve maior massa da matéria seca da parte aérea que nas plantas colonizadas por Acaullospora. Também não houve diferenças entre as plantas colonizadas somente por FMAs. 
As plantas colonizadas por Glomus sp apresentaram significativamente maior produção de matéria seca que as colonizadas por Acaullospora sp., tanto na presença do isolado 3 quanto do isolado 7 , não diferindo inclusive, das plantas que somente receberam a bactéria diazotrófica.

A massa da matéria seca da parte aérea foi maior nos tratamentos com FMAs sozinhos em comparação com os tratamentos em que a bactéria e o fungo micorrízico foram co-inoculados. Não houve efeito sinérgico dos FMAs e bactérias utilizadas na produção de matéria seca pela planta. Possivelmente ocorreu o mesmo efeito já ressaltado para massa da matéria fresca da raiz, pois os tratamentos nos quais a bactéria e o fungo micorrízico foram co-inoculados receberam solução nutritiva sem nitrogênio e os tratamentos com fungo sozinho receberam solução nutritiva com $\mathrm{N}$. Com relação à bactéria diazotrófica também não ocorreu sinergismo. Ao contrário, houve uma interação negativa, parasítica, entre o FMA do gênero Acaullospora e as bactérias diazotróficas, acarretando na diminuição significativa da produção de matéria seca, que somente não diferiu da testemunha que não recebeu nitrogênio (T-N).

Em plantas com alta dependência micorrízica como a mandioca e batata doce, os efeitos sinérgicos são mais pronunciados. Paula et al. (1991) concluem que em plantas de batata doce, os benefícios do efeito sinérgico são devido ao aumento na colonização micorrízica e conseqüentemente maior assimilação de nutrientes do solo e não devido à fixação biológica de $\mathrm{N}_{2}$. A mesma observação foi feita por Balota et al. (1997) para a cultura da mandioca. O trigo devido ao seu sistema radicular fasciculado apresenta pouca dependência micorrízica e os tratamentos em que a bactéria e o FMA foram co-inoculados não promoveram aumento na colonização micorrízica.

Nos tratamentos que continham somente bactérias diazotróficas observou-se maior peso da parte aérea, entretanto, quando as bactérias estavam em conjunto com os FMAs o peso não foi alterado, comparando estes tratamentos com a testemunha que não continha FMA e bactéria e que recebeu a mesma solução nutritiva (T-N). A produção de matéria seca, no entanto, nos 
tratamentos com a bactéria isoladamente ou nos tratamentos com as bactérias co-inoculadas com FMA do gênero Glomus foi 2 vezes maior que na testemunha que recebeu a mesma solução nutritiva (T-N).

Nos tratamentos com FMAs isoladamente, o peso da parte aérea foi significativamente menor que na testemunha que não continha FMA e bactéria e que recebeu a mesma solução nutritiva (T-P). Possivelmente a quantidade de $P$ utilizada na solução nutritiva foi alta, uma vez que o substrato utilizado foi areia e todo $\mathrm{P}$ estava disponível na solução do solo. A planta testemunha, que não continha FMA e bactéria e que recebeu a mesma solução nutritiva (T-P) que os tratamentos com FMAs sozinho, apresentou significativamente maior massa de matéria seca da parte aérea que a testemunha que recebeu solução nutritiva completa $(T+N)$. Pode ter havido um desbalanço nutricional, pois as duas soluções nutritivas continham a mesma quantidade de $\mathrm{N}$, mas a testemunha dos FMAs continha metade da quantidade de $P$ utilizada na solução nutritiva completa. Muitos trabalhos relatam o efeito parasítico de FMAs em níveis altos de P disponível.

Graham \& Abbott (2000) avaliaram o efeito de 10 diferentes espécies de FMAs em trigo e constataram que apenas duas espécies foram capazes de proporcionar maior massa de matéria seca que a testemunha, e somente em baixo nível de $\mathrm{P}$. Os autores sugerem que este efeito esteja relacionado à alta infecção por estes fungos, que os mesmos denominam de agressivos. Já Clark et al. (1999) observaram que não houve correlação entre a porcentagem de colonização e massa da matéria seca da parte aérea ou da raiz em plantas de trigo. A maior colonização foi obtida em plantas colonizadas por Gigaspora margarita, mas estas plantas apresentaram apenas um crescimento moderado (473 mg planta ${ }^{-1}$ ), enquanto plantas colonizadas por Glomus clarum, com $29 \%$ de colonização, apresentaram maior crescimento (1240 mg planta ${ }^{-1}$ ). Entretanto, o aumento da matéria seca somente ocorreu quando a porcentagem de colonização estava acima de $20 \%$. 
Segundo Crosman \& Hill (1987) a magnitude da resposta na interação planta-fungo-bactéria, resultando em aumento no crescimento da planta, é afetada pela quantidade de $\mathrm{P}$ e $\mathrm{N}$ no solo, pela capacidade de infecção do FMA envolvido e da bactéria diazotrófica e pelas diferenças entre os cultivares utilizados.

Tabela 10. Massa da matéria seca da parte aérea. Média de 5 repetições.

\begin{tabular}{cc}
\hline TRATAMENTOS & Massa da matéria seca da parte aérea, g planta ${ }^{-1}$ \\
\hline B1 & 3,08 \\
B1F1 & 3,12 \\
B1F2 & 1,32 \\
B2 & 3,3 \\
B2F1 & 3,12 \\
B2F2 & 0,94 \\
F1 & 6,94 \\
F2 & 7,32 \\
T+N & 6,44 \\
T-N & 1,5 \\
T-P & 8,42
\end{tabular}

B1: isolado 3, IAC-HT-12, B2: isolado 7, IAC-HT-11, F1: Glomus sp., F2: Acaullospora sp., T+N: testemunha que recebeu solução nutritiva completa, T-N: testemunha que recebeu metade da quantidade de $\mathrm{P}$ da solução completa e não recebeu N, T-P: testemunha que recebeu metade da quantidade de $\mathrm{P}$ da solução completa. 
Tabela 11. Teste F para comparação dos contrastes ortogonais obtidos entre os tratamentos para quantificação da massa da matéria seca da parte aérea.

\begin{tabular}{|c|c|c|}
\hline Contrastes ortogonais & $\begin{array}{l}\text { massa da matéria } \\
\text { seca parte aérea }\end{array}$ & \\
\hline \multicolumn{3}{|l|}{ G.L. $=1 \mathrm{e} 42$} \\
\hline $\mathrm{F}_{0}=4,05 \mathrm{P}\left(\mathrm{F}>\mathrm{F}_{0}\right)=5 \%$ & $\mathrm{~F}$ & \\
\hline$B F-F$ & 339,43 & * \\
\hline BF-B & 15,43 & * \\
\hline BF1-BF2 & 40,41 & * \\
\hline B1F-B2F & 0,37 & ns \\
\hline F-T-P & 11,32 & * \\
\hline B - T-N & 19,35 & * \\
\hline BF-T-N & 3,18 & ns \\
\hline B-F & 322,12 & * \\
\hline F1-F2 & 0,73 & ns \\
\hline B1-B2 & 0,25 & ns \\
\hline BF1-B & 0,01 & ns \\
\hline BF2-B & 43,13 & * \\
\hline $\mathrm{T}-\mathrm{P}-\mathrm{T}+\mathrm{N}$ & 20 & * \\
\hline
\end{tabular}

\subsubsection{Teor, quantidade acumulada e índice de eficiência de utilização do N na parte aérea.}

Quando avaliaram os tratamentos em que bactéria e fungo micorrízico foram co-inoculados em comparação com os tratamentos que receberam FMAs ou bactérias isoladamente, os tratamentos que continham somente bactéria diazotrófica apresentaram significativamente menor teor de $\mathrm{N}$, igual quantidade acumulada e maior índice de eficiência de utilização. Os tratamentos que continham somente FMAs apresentaram maior teor, quantidade acumulada e índice de eficiência de utilização do $\mathrm{N}$ quando comparados aos tratamentos em 
que as bactérias e os FMAs foram co-inoculados. Provavelmente este efeito foi devido à diferença na solução nutritiva, quanto à quantidade de $\mathrm{N}$ utilizada (Tabelas 12 e 13).

Nos tratamentos em que a bactéria e o fungo micorrízico foram coinoculados, o fungo micorrízico utilizado somente não influenciou o teor de $\mathrm{N}$, mas o FMA do gênero Glomus propiciou maior quantidade acumulada de $\mathrm{N} \mathrm{e}$ maior índice de eficiência de utilização, independente da bactéria, devido a maior massa de matéria seca da parte aérea. Entretanto, os tratamentos que continham somente FMA não diferiram entre si.

A bactéria diazotrófica utilizada não influenciou o teor, quantidade acumulada ou o índice de eficiência de utilização do $\mathrm{N}$ na parte aérea quando comparado com os tratamentos em que a bactéria e o fungo micorrízico foram co-inoculados, e também, quando comparado os tratamentos nos quais as bactérias foram inoculadas isoladamente; ou seja, não houve diferença entre as bactérias utilizadas na absorção e no aproveitamento do $\mathrm{N}$ pela planta.

Comparando os tratamentos que continham somente bactérias diazotróficas ou bactérias conjuntamente com FMAs em relação à testemunha que não continha FMA e bactéria e que recebeu a mesma solução nutritiva (T$N$ ), observou-se que nos tratamentos que continham somente bactérias diazotróficas obteve-se menor teor, mas o dobro da quantidade acumulada e do índice de eficiência de utilização do N. Entretanto, quando as bactérias estavam em conjunto com os FMAs, o teor e a quantidade acumulada de $\mathrm{N}$ não foi alterada, porém obteve-se maior IEU do N.

Nos tratamentos com FMAs isoladamente, 0 teor de $\mathrm{N}$ foi significativamente maior que na testemunha que não continha FMA e bactéria e que recebeu a mesma solução nutritiva, mas não houve diferença na quantidade acumulada de $\mathrm{N}$ e no índice de eficiência de utilização.

Nos tratamentos que continham somente FMAs, O IEU do $\mathrm{N}$ foi significativamente maior que na testemunha que recebeu solução nutritiva completa $(T+N)$. O IEU de $N$ das plantas desta mesma testemunha não diferiu 
significativamente do índice das plantas dos tratamentos com bactérias isoladamente e das plantas colonizadas por Glomus sp. e na presença dos isolados bacterianos. Entretanto, foi significativamente maior que nas plantas colonizadas por Acaullospora sp., para ambos os isolados.

$\mathrm{O}$ IEU de $\mathrm{N}$ não diferiu entre os tratamentos que receberam somente FMA e a testemunha que recebeu a mesma solução nutritiva (T-P), porem, os tratamentos com FMAs sozinhos apresentaram maior IEU que a testemunha que recebeu solução nutritiva completa $(T+N)$. As duas testemunhas receberam a mesma quantidade de $\mathrm{N}$, mas para a testemunha que recebeu a mesma solução nutritiva dos tratamentos com FMA sozinho, foi empregada metade da quantidade de $\mathrm{P}$ utilizada na solução completa, e obteve-se maior massa da matéria seca da parte aérea nesta última. A mesma testemunha apresentou igual quantidade acumulada e maior índice de eficiência de utilização de $\mathrm{N}$ e P que a testemunha que recebeu solução nutritiva completa. 
Tabela 12. Teor, quantidade acumulada e índice de eficiência de utilização do nitrogênio na parte aérea. Média de 5 repetições.

\begin{tabular}{cccc}
\hline TRATAMENTOS & $\begin{array}{c}\text { TEOR-N } \\
\mathrm{g} \mathrm{kg}^{-1}\end{array}$ & $\begin{array}{c}\text { Qa-N } \\
\text { mg planta }^{-1}\end{array}$ & $\begin{array}{c}\text { IEU-N } \\
g^{2} \text { planta }^{-1}\end{array}$ \\
\hline B1 & 12,75 & 38 & 236 \\
B1F1 & 11,98 & 37 & 265 \\
B1F2 & 14,73 & 19 & 93 \\
B2 & 13,51 & 45 & 247 \\
B2F1 & 15,15 & 47 & 211 \\
B2F2 & 14,65 & 14 & 66 \\
F1 & 19,62 & 134 & 362 \\
F2 & 19,72 & 144 & 374 \\
T+N & 25,28 & 161 & 261 \\
T-N & 14,45 & 21 & 108 \\
T-P & 19,09 & 159 & 439
\end{tabular}

B1: isolado 3, IAC-HT-12, B2: isolado 7, IAC-HT-11, F1: Glomus sp., F2: Acaullospora sp., T+N: testemunha que recebeu solução nutritiva completa, T-N: testemunha que recebeu metade da quantidade de $\mathrm{P}$ da solução completa e não recebeu N, T-P: testemunha que recebeu metade da quantidade de P da solução completa. 
Tabela 13. Teste F para comparação dos contrastes ortogonais obtidos entre os tratamentos para quantificação do teor, quantidade acumulada e índice de eficiência de utilização do nitrogênio na parte aérea.

\begin{tabular}{|c|c|c|c|c|c|c|}
\hline Contrastes ortogonais & teor-N & & Qa-N & & IEU-N & \\
\hline \multicolumn{7}{|l|}{ G.L. $=1$ e 41} \\
\hline$F_{0}=4,08 \quad P\left(F>F_{0}\right)=5 \%$ & $\mathrm{~F}$ & & $\mathrm{~F}$ & & $\mathrm{~F}$ & \\
\hline B-BF & 9,93 & * & 2,38 & ns & 11,99 & * \\
\hline F-BF & 55,45 & * & 392,39 & * & 138,57 & * \\
\hline BF1-BF2 & 1,71 & ns & 17,11 & * & 59,55 & * \\
\hline B1F-B2F & 3,23 & ns & 0,16 & ns & 3,83 & ns \\
\hline $\mathrm{F} 1-\mathrm{F} 2$ & 0,01 & ns & 1,32 & ns & 0,17 & ns \\
\hline B1-B2 & 7,40 & * & 2,43 & ns & 4,04 & ns \\
\hline F - T-P & 20,11 & * & 0,99 & ns & 0,49 & ns \\
\hline$B-T-N$ & 6,28 & * & 4,76 & * & 20,10 & * \\
\hline BF-T-N & 0,12 & ns & 1,43 & ns & 5,00 & * \\
\hline $\mathrm{F}-\mathrm{T}+\mathrm{N}$ & 28,35 & * & 10,96 & * & 18,01 & * \\
\hline $\mathrm{B}-\mathrm{T}+\mathrm{N}$ & 167,97 & * & 273,68 & * & 3,04 & ns \\
\hline $\mathrm{BF}-\mathrm{T}+\mathrm{N}$ & 134,58 & * & 359,91 & * & 19,97 & * \\
\hline
\end{tabular}

B1: isolado 3, IAC-HT-12, B2: isolado 7, IAC-HT-11, F1: Glomus sp., F2: Acaullospora sp., T+N : testemunha que recebeu solução nutritiva completa, T-N: testemunha que recebeu metade da quantidade de $\mathrm{P}$ da solução completa e não recebeu N, T-P: testemunha que recebeu metade da quantidade de $\mathrm{P}$ da solução completa.

\subsubsection{Teor, quantidade acumulada e índice de eficiência de utilização do P na parte aérea.}

A bactéria utilizada nos tratamentos em que bactéria e fungo micorrízico foram co-inoculados influenciou somente o teor de $P$, ou seja, onde o isolado 7 foi inoculado obteve-se maior teor de $P$ na parte aérea em relação ao isolado 3 . Entretanto não houve diferença entre os tratamentos quando se avaliou a quantidade acumulada ou o IEU do P. A colonização micorrízica também foi maior nos tratamentos em que o isolado 7 foi co-inoculado com os FMAs. Não 
houve diferenças entre os tratamentos que continham somente bactérias diazotróficas quanto à absorção e aproveitamento do $P$ (Tabelas 14 e 15).

O FMA utilizado nos tratamentos em que bactéria e fungo micorrízico foram inoculados conjuntamente influenciou o teor, a quantidade acumulada e $o$ IEU do P. Nos tratamentos com FMA do gênero Acaullospora obteve-se significativamente maior teor de P que com o gênero Glomus, mas houve efeito inverso na Qa e IEU do P, ou seja, nas plantas colonizadas por Glomus obtevese maior quantidade acumulada e IEU que nas colonizadas por Acaullospora. Provavelmente este efeito foi devido a maior matéria seca das plantas colonizadas por Glomus para ambas as bactérias.

Os tratamentos com FMAs isoladamente não diferiram entre si no teor e quantidade acumulada de $\mathrm{P}$, mas houve maior IEU do $\mathrm{P}$ nas plantas colonizadas por Glomus que nas colonizadas por Acaullospora.

Quando se avaliaram os tratamentos em que bactéria e fungo micorrízico foram co-inoculados em comparação com os tratamentos que receberam o FMA ou a bactéria isoladamente, as plantas dos tratamentos que continham somente bactéria diazotrófica apresentaram menor teor de $P$, mas não houve diferenças na quantidade acumulada e no IEU do P. As plantas dos tratamentos que continham somente FMA apresentaram significativamente menor teor de $\mathrm{P}$ e maior quantidade acumulada e índice de eficiência de utilização do $P$.

Comparando os tratamentos que continham somente bactérias diazotróficas ou bactérias conjuntamente com FMAs em relação à testemunha que não continha FMA e bactéria e que recebeu a mesma solução nutritiva (T$\mathrm{N}$ ), observou-se que nos tratamentos que continham somente bactérias diazotróficas obteve-se igual teor de $\mathrm{P}$, mas o dobro da quantidade acumulada e o triplo do índice de eficiência de utilização. Entretanto, quando as bactérias estavam em conjunto com os FMAs o teor e o IEU não foi alterado, e obteve-se menor quantidade acumulada de $P$. Pode-se concluir que a interação FMAbactéria resultou em efeito negativo sobre o acúmulo e o aproveitamento de $\mathrm{P}$ pelas plantas, provavelmente devido à competição por nutrientes entre fungos e 
bactérias, uma vez que o teor não foi alterado, mas a planta não conseguiu converter em matéria seca.

Plantas dependentes da fixação biológica de $\mathrm{N}_{2}$ geralmente possuem maior demanda de $\mathrm{P}$ do que as plantas que recebem fertilizante nitrogenado, pois existe um aumento no consumo de ATP para o funcionamento da nitrogenase, além do necessário para transdução de sinais entre a planta e os microrganismos. A seleção da planta para fixação do $\mathrm{N}$ em baixo nível de $\mathrm{P}$ deve ser acompanhada por uma seleção paralela para tolerância a baixo requerimento de P pelo microrganismo envolvido (Graham \& Vance, 2000).

Os tratamentos que continham somente FMAs não diferiram da testemunha sem FMA e bactéria e que recebeu a mesma solução nutritiva (T-P) quando se avaliou o teor e IEU do $\mathrm{P}$, mas obteve-se significativamente menor quantidade acumulada de P. O mesmo tratamento apresentou menor massa de matéria seca da parte aérea que a testemunha, demonstrando um efeito parasítico. Porem, o tratamento testemunha que recebeu solução nutritiva completa $(T+N)$ apresentou maior teor, não diferiu quanto à quantidade acumulada e menor IEU de $P$ que os tratamentos com FMAs isoladamente, possivelmente houve um desbalanço nutricional como comentado anteriormente.

O tratamento testemunha sem FMAs ou bactérias que recebeu solução nutritiva completa $(T+N)$ apresentou significativamente maior quantidade acumulada de $P$ que os tratamentos com bactérias isoladamente, mas não diferiu quanto ao teor e IEU de P. Neste mesmo tratamento, as plantas tiveram significativamente menor teor de $\mathrm{P}$ e maior quantidade acumulada e IEU de $\mathrm{P}$ que nas plantas dos tratamentos em que bactéria e fungo micorrízico foram coinoculados. 
Tabela 14. Teor, quantidade acumulada e índice de eficiência de utilização do fósforo na parte aérea. Média de 5 repetições.

\begin{tabular}{cccc}
\hline TRATAMENTOS & $\begin{array}{c}\text { TEOR-P } \\
\mathrm{g} \mathrm{kg}^{-1}\end{array}$ & $\begin{array}{c}\text { Qa-P } \\
\text { mg planta }^{-1}\end{array}$ & $\begin{array}{c}\text { IEU-P } \\
g^{2} \text { planta }^{-1}\end{array}$ \\
\hline B1 & 2,36 & 8 & 1357 \\
B1F1 & 2,11 & 7 & 1598 \\
B1F2 & 3,05 & 5 & 532 \\
B2 & 2,43 & 8 & 1327 \\
B2F1 & 2,62 & 9 & 1287 \\
B2F2 & 3,57 & 4 & 323 \\
F1 & 1,33 & 11 & 5988 \\
F2 & 1,46 & 9 & 4350 \\
T+N & 1,97 & 12 & 3328 \\
T-N & 2,82 & 4 & 456 \\
T-P & 1,55 & 14 & 5846 \\
\hline
\end{tabular}

B1: isolado 3, IAC-HT-12, B2: isolado 7, IAC-HT-11, F1: Glomus sp., F2: Acaullospora sp., T+N: testemunha que recebeu solução nutritiva completa, T-N: testemunha que recebeu metade da quantidade de $\mathrm{P}$ da solução completa e não recebeu N, T-P: testemunha que recebeu metade da quantidade de P da solução completa. 
Tabela 15 . Teste F para comparação dos contrastes ortogonais obtidos entre os tratamentos para quantificação do teor, quantidade acumulada e índice de eficiência de utilização do $P$ na parte aérea.

\begin{tabular}{|c|c|c|c|c|c|c|}
\hline Contrastes ortogonais & teor-P & & Qa-P & & IEU-P & \\
\hline \multicolumn{7}{|l|}{ G.L. $=1$ e 22} \\
\hline$F_{0}=4,3 \quad P\left(F>F_{0}\right)=5 \%$ & $\mathrm{~F}$ & & $\mathrm{~F}$ & & $\mathrm{~F}$ & \\
\hline B-BF & 4,33 & * & 2,90 & ns & 2,51 & ns \\
\hline F-BF & 44,99 & * & 19,00 & * & 266,25 & * \\
\hline BF1-BF2 & 14,48 & * & 12,60 & * & 11,46 & * \\
\hline B1F-B2F & 4,30 & * & 0,12 & ns & 0,75 & ns \\
\hline $\mathrm{F} 1-\mathrm{F} 2$ & 0,14 & ns & 0,85 & ns & 14,92 & * \\
\hline B1-B2 & 0,03 & ns & 0,04 & ns & 0,01 & ns \\
\hline F - T-P & 0,26 & ns & 8,88 & * & 3,40 & ns \\
\hline$B-T-N$ & 2,00 & ns & 10,94 & * & 5,87 & * \\
\hline BF-T-N & 0,00 & ns & 5,30 & * & 2,04 & ns \\
\hline $\mathrm{F}-\mathrm{T}+\mathrm{N}$ & 3,57 & * & 4,00 & ns & 25,15 & * \\
\hline $\mathrm{B}-\mathrm{T}+\mathrm{N}$ & 1,91 & ns & 15,04 & * & 29,18 & * \\
\hline $\mathrm{BF}-\mathrm{T}+\mathrm{N}$ & 9,76 & * & 31,00 & * & 51,06 & * \\
\hline
\end{tabular}

testemunha que recebeu solução nutritiva completa, T-N: testemunha que recebeu metade da quantidade de $\mathrm{P}$ da solução completa e não recebeu $\mathrm{N}, \mathrm{T}-\mathrm{P}$ : testemunha que recebeu metade da quantidade de $\mathrm{P}$ da solução completa.

Possivelmente, existe uma interação direta ou indireta entre bactérias diazotróficas e os FMAs, ocorrendo alguma mudança fisiológica, mediada pela produção de reguladores de crescimento, metabólicos secundários, ou devido a outros sinais moleculares da planta hospedeira.

Os microsimbiontes possuem diferentes habitats na rizosfera, como os nódulos no caso dos rizóbios, e como o interior das raízes no caso das bactérias diazotróficas associativas ou dos FMAs. Ambos microrganismos fixadores de $\mathrm{N}$ podem colonizar todo sistema radicular. Deve existir uma interação funcional entre as bactérias e os FMAs (Paula et al., 1992). Os 
rizóbios ficam separados, devido à fixação do $\mathrm{N}$ dentro dos nódulos, geralmente não ocorre competição entre rizóbios e FMAs. Já as bactérias diazotróficas associativas não estão separadas dos FMAs, podendo resultar em competição por nutrientes entre os dois microrganismos. Segundo Biró et al. (2000) o sucesso da co-inoculação depende do estado fisiológico, do tempo de infecção ou da demanda nutricional dos microsimbiontes. Cada interação bactéria-fungoplanta é bastante específica, havendo necessidade de se conhecer a influência dos diversos fatores, abióticos e bióticos, para o sucesso da interação e melhor manejo das culturas. 


\section{CONCLUSÃo}

- O genótipo da planta e a adubação nitrogenada influenciaram a quantidade de microrganismos diazotróficos endofíticos nas raízes da cultura do trigo.

- O genótipo IAC-355 apresentou a menor colonização radicular por bactérias diazotróficas endofíticas., não havendo isolamento de Azospirillum sp., Herbaspirillum sp. ou G. diazotrophicus neste genótipo.

- Nas condições estudadas não foi encontrado G. diazotrophicus nas raízes desinfestadas superficialmente de plantas de trigo.

- A quantidade de $\mathrm{N}$ adicionada como adubo não foi um fator limitante para quantificação de bactérias diazotróficas endofíticas.

- No genótipo ITD-19 os isolados de bactérias diazotróficas endofíticas propiciaram maior comprimento radicular e somente um isolado de Herbaspirillum sp. proporcionou maior teor de $\mathrm{N}$ na parte aérea.

- O genótipo IAC-355 apresentou a maior colonização por FMAs. A quantidade de $\mathrm{N}$ utilizada não foi um fator limitante para formação da micorriza. A colonização por FMAs apresentou correlação positiva com o teor de $\mathrm{N}$ e $\mathrm{P}$, e com a quantidade acumulada de $\mathrm{N}$ e $\mathrm{P}$ na parte aérea, assim como, com a massa da matéria seca na parte aérea e com a produtividade.

- Houve correlação entre o $\mathrm{qCO}_{2}$ e a relação Cmic:Corg, indicando que na ausência de $\mathrm{N}$ adicionado houve perdas de $\mathrm{C}$ no solo sob influência do cultivar IAC-24, enquanto que no solo sob influência do cultivar IAC-355 a microbiota foi mais eficiente na utilização do $\mathrm{C}$ do solo.

- O genótipo influenciou a quantidade de microrganismos amonificadores, mas não interferiu no processo de nitrificação da amônia no solo. As populações de bactérias nitrificadoras aumentaram em função da dose de $\mathrm{N}$ adicionada. $\mathrm{A}$ 
quantidade de bactérias nitrificantes se correlacionou com o teor e com a quantidade acumulada de $\mathrm{N}$ na parte aérea, assim como, com a massa da matéria seca da parte aérea e com a produtividade.

- A interação FMA-bactéria diazotrófica não propiociou benefícios para cultura do trigo e demonstrou ser bastante especifica.

- Confirmou-se que o fungo micorrízico realmente é um agente transmissor de bactérias diazotróficas endofíticas, sendo que Acaullospora causou maior colonização radicular.

- Independentemente da bactéria diazotrófica co-inoculada com o fungo micorrízico do gênero Glomus houve aumento no crescimento, acúmulo e aproveitamento dos nutrientes pelas plantas.

- A inoculação das bactérias diazotróficas endofíticas causou o dobro de crescimento, acúmulo e aproveitamento do $\mathrm{N}$ e do $\mathrm{P}$ pelas plantas em relação à testemunha. 
Anexos 
Tabela 1. Quantificação de microrganismos em 3 meios de cultura; NFb, semi-específico para Azospirillum sp., JNFb, semi-específico para Herbaspirillum sp. e LGI-P, semi-específico para Gluconacetobacter diazotrophicus, na raiz de 3 genótipos de trigo cultivados com 3 doses crescentes de $\mathrm{N}$ (média de 3 repetições) ${ }^{1 /}$.

\begin{tabular}{|c|c|c|c|c|c|}
\hline \multirow{2}{*}{$\begin{array}{l}\text { Tratamentos } \\
\text { GENÓTIPOS }\end{array}$} & \multicolumn{3}{|c|}{ Doses de N, Kg.ha ${ }^{-1}$} & \multirow[b]{2}{*}{$\begin{array}{l}\text { Média } \\
\text { doses }\end{array}$} & \multirow[b]{2}{*}{$\begin{array}{l}\text { Regressão polinomial } \\
(1)\end{array}$} \\
\hline & 0 & 60 & 120 & & \\
\hline \multicolumn{6}{|l|}{ Meio NFb $(\log x+1)$} \\
\hline IAC-24 & $7,50 \mathrm{a}$ & $6,58 \mathrm{~b}$ & $7,66 \mathrm{~b}$ & 7,33 ab & ns \\
\hline ITD-19 & $7,67 \mathrm{a}$ & $8,20 a$ & 8,32 ab & $8,06 \mathrm{a}$ & ns \\
\hline $\begin{array}{l}\text { IAC-355 } \\
\text { Rearessão polinomial(2) }\end{array}$ & $4,98 \mathrm{~b}$ & $6,77 \mathrm{~b}$ & $9,23 \mathrm{a}$ & $6,99 \mathrm{~b}$ & $\begin{array}{l}Y=4,867+0,035 \times r^{2}=0,84 \\
\text { ns }\end{array}$ \\
\hline Dms & 1,52 & & & 0,88 & \\
\hline Meio NFb, $\mathrm{n}^{0} 10^{5} \mathrm{~g}^{-1}$ raíz & & & & & \\
\hline IAC-24 & $210 a$ & $8,00 \mathrm{~b}$ & $320 \mathrm{~b}$ & & \\
\hline ITD-19 & $111 \mathrm{a}$ & 389 a & $370 a b$ & & \\
\hline IAC-355 & $0,152 b$ & $23,39 \mathrm{~b}$ & 3650 a & & \\
\hline \multicolumn{6}{|l|}{ Meio JNFb $(\log x+1)$} \\
\hline IAC-24 & $7,58 \mathrm{a}$ & $7,99 a$ & $7,64 \mathrm{a}$ & $7,74 \mathrm{a}$ & ns \\
\hline ITD-19 & $7,21 \mathrm{a}$ & $7,49 a$ & $7,67 \mathrm{a}$ & $7,46 \mathrm{a}$ & \\
\hline IAC-355 & $3,79 \mathrm{~b}$ & $5,96 \mathrm{a}$ & $8,19 a$ & $5,98 \mathrm{~b}$ & $Y=3,783+0,037 \times r^{2}=0,82$ \\
\hline Regressão polinomial(2) & & & & & ns \\
\hline $\begin{array}{l}\text { Dms } \\
\text { Meio JNFb n }{ }^{0} 10^{5} \mathrm{~g}^{-1} \text { raíz }\end{array}$ & 2,05 & & & 1,18 & \\
\hline IAC-24 & 306 a & $321 \quad \mathrm{a}$ & $543 a$ & & \\
\hline ITD-19 & $24,00 \mathrm{a}$ & $71,67 \mathrm{a}$ & $538 a$ & & \\
\hline IAC-355 & $0,009 \mathrm{~b}$ & $5,34 a$ & $389 a$ & & \\
\hline \multicolumn{6}{|l|}{ Meio LGI-P $(\log x+1)$} \\
\hline IAC-24 & $6,98 \mathrm{a}$ & $6,88 \mathrm{a}$ & $6,67 \mathrm{a}$ & $6,85 a$ & ns \\
\hline ITD-19 & $6,31 \mathrm{a}$ & $6,88 \mathrm{a}$ & $7,56 \mathrm{a}$ & $6,92 \mathrm{a}$ & ns \\
\hline IAC-355 & $2,89 b$ & $4,64 \mathrm{~b}$ & $6,85 \mathrm{a}$ & $4,79 \mathrm{~b}$ & $Y=2,818+0,033 \times r^{2}=0,66$ \\
\hline Regressão polinomial(2) & & & & & ns \\
\hline $\begin{array}{l}\text { Dms } \\
\text { Meio LGI-P n } 10^{5} \mathrm{~g}^{-1} \text { raíz }\end{array}$ & 2,19 & & & 1,26 & \\
\hline IAC-24 & $64,10 \mathrm{a}$ & $38,60 \mathrm{a}$ & $12,50 \mathrm{a}$ & & \\
\hline ITD-19 & $3,34 \mathrm{a}$ & $18,67 \mathrm{a}$ & 109 a & & \\
\hline IAC-355 & $0,005 \mathrm{~b}$ & $0,058 \mathrm{~b}$ & 119 a & & \\
\hline
\end{tabular}


Tabela 2. Comprimento da raiz principal, altura, massa da matéria seca e teor de $\mathrm{N}$ na parte aérea do genótipo IAC-24 submetido a diferentes isolados bacterianos(média de 3 repetições) ${ }^{1 /}$.

\begin{tabular}{lllll}
\hline IAC-24 & Raiz $(\mathrm{cm})$ & Altura $(\mathrm{cm})$ & Peso $(\mathrm{mg})$ & Teor N $\left(\mathrm{mg} \mathrm{kg}^{-1}\right)$ \\
\hline 1 & $15,66 \mathrm{~b}$ & $24,66 \mathrm{~b}$ & $24,67 \mathrm{a}$ & $338,33 \mathrm{a}$ \\
2 & $17,33 \mathrm{~b}$ & $26,83 \mathrm{~b}$ & $31,67 \mathrm{a}$ & $418,50 \mathrm{a}$ \\
3 & $19,00 \mathrm{~b}$ & $21,50 \mathrm{~b}$ & $23,00 \mathrm{a}$ & $583,33 \mathrm{a}$ \\
4 & $16,33 \mathrm{~b}$ & $28,00 \mathrm{~b}$ & $33,67 \mathrm{a}$ & $362,67 \mathrm{a}$ \\
5 & $11,33 \mathrm{c}$ & $19,83 \mathrm{c}$ & $21,00 \mathrm{a}$ & $424,33 \mathrm{a}$ \\
6 & $31,66 \mathrm{a}$ & $26,33 \mathrm{~b}$ & $34,33 \mathrm{a}$ & $448,73 \mathrm{a}$ \\
7 & $18,66 \mathrm{~b}$ & $25,33 \mathrm{~b}$ & $33,00 \mathrm{a}$ & $317,00 \mathrm{a}$ \\
8 & $15,33 \mathrm{~b}$ & $25,16 \mathrm{~b}$ & $21,67 \mathrm{a}$ & $466,87 \mathrm{a}$ \\
9 & $23,00 \mathrm{~b}$ & $24,50 \mathrm{~b}$ & $25,33 \mathrm{a}$ & $526,67 \mathrm{a}$ \\
10 & $26,33 \mathrm{~b}$ & $29,66 \mathrm{a}$ & $33,67 \mathrm{a}$ & $627,67 \mathrm{a}$ \\
11 & $25,66 \mathrm{~b}$ & $28,50 \mathrm{~b}$ & $30,33 \mathrm{a}$ & $607,00 \mathrm{a}$ \\
12 & $26,66 \mathrm{~b}$ & $27,16 \mathrm{~b}$ & $32,70 \mathrm{a}$ & $455,83 \mathrm{a}$ \\
13 & $13,66 \mathrm{c}$ & $25,00 \mathrm{~b}$ & $29,33 \mathrm{a}$ & $743,17 \mathrm{a}$ \\
testemunha & $21,66 \mathrm{~b}$ & $25,33 \mathrm{~b}$ & $26,00 \mathrm{a}$ & $382,67 \mathrm{a}$ \\
Z-67 & $16,00 \mathrm{~b}$ & $25,83 \mathrm{~b}$ & $29,33 \mathrm{a}$ & $346,50 \mathrm{a}$ \\
SP-59b & $16,33 \mathrm{~b}$ & $21,33 \mathrm{c}$ & $20,80 \mathrm{a}$ & $479,50 \mathrm{a}$ \\
\hline
\end{tabular}

"Letras iguais não diferem entre si pelo teste de Dunnett a $5 \%$ de probabilidade

Tabela 3. Comprimento da raiz principal, altura, massa da matéria seca e teor de $\mathrm{N}$ na parte aérea do genótipo ITD-19 submetido a diferentes isolados bacterianos(média de 3 repetições) ${ }^{1 /}$.

\begin{tabular}{llllr}
\hline ITD-19 & Raiz $(\mathrm{cm})$ & Altura $(\mathrm{cm})$ & Peso $(\mathrm{mg})$ & TeorN $\left(\mathrm{mg} \mathrm{kg}^{-1}\right)$ \\
\hline 1 & $42,33 \mathrm{a}$ & $24,33 \mathrm{a}$ & $33,00 \mathrm{a}$ & $581,00 \mathrm{~b}$ \\
2 & $35,00 \mathrm{a}$ & $23,83 \mathrm{a}$ & $30,50 \mathrm{a}$ & $373,33 \mathrm{~b}$ \\
3 & $38,00 \mathrm{a}$ & $22,33 \mathrm{~b}$ & $34,83 \mathrm{a}$ & $1927,00 \mathrm{a}$ \\
4 & $22,66 \mathrm{a}$ & $19,33 \mathrm{~b}$ & $28,50 \mathrm{a}$ & $576,67 \mathrm{~b}$ \\
5 & $29,00 \mathrm{a}$ & $23,66 \mathrm{a}$ & $30,33 \mathrm{a}$ & $699,37 \mathrm{~b}$ \\
6 & $21,33 \mathrm{a}$ & $25,50 \mathrm{a}$ & $34,67 \mathrm{a}$ & $501,67 \mathrm{~b}$ \\
7 & $17,66 \mathrm{a}$ & $24,50 \mathrm{a}$ & $32,83 \mathrm{a}$ & $926,67 \mathrm{~b}$ \\
testemunha & $11,66 \mathrm{~b}$ & $20,83 \mathrm{~b}$ & $30,50 \mathrm{a}$ & $468,50 \mathrm{~b}$ \\
Z-67 & $27,33 \mathrm{a}$ & $23,00 \mathrm{~b}$ & $31,40 \mathrm{a}$ & $415,33 \mathrm{~b}$ \\
SP-59b & $30,33 \mathrm{a}$ & $22,33 \mathrm{~b}$ & $31,83 \mathrm{a}$ & $617,83 \mathrm{~b}$ \\
\hline
\end{tabular}

" Letras iguais não diferem entre si pelo teste de Dunnett a $5 \%$ de probabilidade 
Tabela 4. Quantificação de esporos de FMAs no solo, e da colonização micorrízica nas raízes em 3 genótipos de trigo cultivados com 3 doses crescentes de $\mathrm{N}$ (média de 3 repetições) ${ }^{1 /}$.

\begin{tabular}{|c|c|c|c|c|c|}
\hline \multirow{2}{*}{$\begin{array}{l}\text { Tratamentos } \\
\text { GENÓTIPOS }\end{array}$} & \multicolumn{3}{|c|}{ Doses de N, Kg.ha ${ }^{-1}$} & \multirow{2}{*}{$\begin{array}{l}\text { Média } \\
\text { doses }\end{array}$} & \multirow[b]{2}{*}{ Regressão polinomial (1) } \\
\hline & 0 & 60 & 120 & & \\
\hline \multicolumn{6}{|c|}{$\mathrm{n}^{0}$ de esporos $50 \mathrm{~g}$ de solo ${ }^{-1}$} \\
\hline IAC-24 & $988,00 \mathrm{a}$ & $866.67 \mathrm{a}$ & $608,67 \mathrm{a}$ & $821 \mathrm{a}$ & $Y=1010,80+3,161 \times r^{2}=0,66$ \\
\hline ITD-19 & $532,00 \mathrm{~b}$ & $851,00 \mathrm{a}$ & $721,67 \mathrm{a}$ & 702 b & $\begin{array}{l}Y=532+9,053 x+0,062 x^{2} \\
r^{2}=0,77\end{array}$ \\
\hline IAC-355 & $1008,67 \mathrm{a}$ & $897,67 \mathrm{a}$ & $702,67 \mathrm{a}$ & $874 a$ & $Y=1031,60+2,997 \times r^{2}=0,61$ \\
\hline $\begin{array}{l}\text { Regressão } \\
\text { polinomial(2) }\end{array}$ & & & & & ns \\
\hline Dms & 151,18 & & & 87,28 & \\
\hline \multicolumn{6}{|c|}{ FMA $(\operatorname{arcsenVx} / 100)$} \\
\hline IAC-24 & $0,76 \mathrm{a}$ & $0,80 \mathrm{a}$ & $0,79 \mathrm{~b}$ & $0,78 \mathrm{~b}$ & ns \\
\hline ITD-19 & $0,68 \mathrm{a}$ & $0,76 \mathrm{a}$ & $0,85 b$ & $0,76 \mathrm{~b}$ & $Y=0,683+0,001 \times r^{2}=0,78$ \\
\hline IAC-355 & $0,76 \mathrm{a}$ & $0,87 \mathrm{a}$ & $0,97 \mathrm{a}$ & $0,86 a$ & $Y=0,762+0,002 \times r^{2}=0,83$ \\
\hline $\begin{array}{l}\text { Regressão } \\
\text { polinomial(2) }\end{array}$ & & & & & $Y=0,739+0,001 \times r^{2}=0,41$ \\
\hline Dms & 0,087 & & & 0,050 & \\
\hline \multicolumn{6}{|c|}{ FMA - \% de colonização } \\
\hline IAC-24 & $48 \mathrm{a}$ & $40 \mathrm{a}$ & $47 \mathrm{a}$ & & \\
\hline ITD-19 & $52 \mathrm{a}$ & $47 a$ & $58 a$ & & \\
\hline IAC-355 & $50 \mathrm{~b}$ & $56 \mathrm{~b}$ & $67 \mathrm{a}$ & & \\
\hline
\end{tabular}

"Letras iguais não diferem entre si pelo teste de T-student a $5 \%$. As letras são para comparação entre genótipos na vertical. dms: diferença mínima significativa (1) regressão polinomial para doses dentro de cada genótipo, (2) regressão polinomial para doses, independentemente do genótipo. 
Tabela 5. Análise do carbono e do nitrogênio da biomassa microbiana, e das relações Cmic : Nmic, Cmic : Corg no solo rizosférico de 3 genótipos de trigo cultivados com 3 doses crescentes de N.

\begin{tabular}{|c|c|c|c|c|c|}
\hline \multirow{2}{*}{$\begin{array}{l}\text { Tratamentos } \\
\text { GENÓTIPOS }\end{array}$} & \multicolumn{3}{|c|}{ Doses de N, Kg.ha ${ }^{-1}$} & \multirow[b]{2}{*}{$\begin{array}{l}\text { Média } \\
\text { doses }\end{array}$} & \multirow[b]{2}{*}{ Regressão polinomial (1 } \\
\hline & 0 & 60 & 120 & & \\
\hline \multicolumn{6}{|c|}{ Biomassa-C, $\mu \mathrm{gC} \mathrm{g}{ }^{-1}$ de solo } \\
\hline IAC-24 & $219,13 b$ & $293,90 \mathrm{a}$ & $407,81 \mathrm{a}$ & 306,9 a & $\mathrm{ns}$ \\
\hline ITD-19 & $302,45 a b$ & $405,73 \mathrm{a}$ & $328,11 \mathrm{a}$ & $345,4 a$ & ns \\
\hline IAC-355 & $437,24 \mathrm{a}$ & $447,94 \mathrm{a}$ & $371,53 \mathrm{a}$ & $418,9 \mathrm{a}$ & ns \\
\hline $\begin{array}{l}\text { Regressão } \\
\text { polinomial(2) }\end{array}$ & & & & & ns \\
\hline Dms & 176,51 & & & 101,91 & \\
\hline \multicolumn{6}{|c|}{ Biomassa- $\mathrm{N}, \mu \mathrm{gNg}{ }^{-1}$ de solo } \\
\hline IAC-24 & $56,14 \mathrm{a}$ & $46,61 \mathrm{ab}$ & $23,16 \mathrm{~b}$ & $41,97 \mathrm{~b}$ & $y=58,462-0,0275 \times r^{2}=0,76$ \\
\hline ITD-19 & $57,58 \mathrm{a}$ & 40,72 b & $59,23 \mathrm{a}$ & $52,51 \mathrm{a}$ & ns \\
\hline IAC-355 & $64,54 \mathrm{a}$ & $58,68 \mathrm{a}$ & $65,75 \mathrm{a}$ & $56,33 \mathrm{a}$ & ns \\
\hline $\begin{array}{l}\text { Regressão } \\
\text { polinomial(2) }\end{array}$ & & & & & ns \\
\hline Dms & 16,28 & & & 9,40 & \\
\hline \multicolumn{6}{|l|}{$\mathrm{C}_{\text {mic }}: \mathrm{C}_{\text {org }}$} \\
\hline IAC-24 & $13,96 \mathrm{~b}$ & $23,46 a$ & $28,85 a$ & $22,09 a$ & ns \\
\hline ITD-19 & $17,47 \mathrm{~b}$ & $32,91 \mathrm{a}$ & $23,38 \mathrm{a}$ & $24,59 a$ & $y=17,467+0,465 x-0,003 x^{2}$ \\
\hline IAC-355 & $32,78 \mathrm{a}$ & $31,75 a$ & $27,90 \mathrm{a}$ & $30,81 \mathrm{a}$ & $r^{2}=0,67$ \\
\hline Regressão & & & & & ns \\
\hline polinomial(2) & & & & & ns \\
\hline Dms & 14,54 & & & 8,39 & \\
\hline \multicolumn{6}{|l|}{$\mathrm{C}_{\mathrm{mic}}: \mathrm{N}_{\mathrm{mic}}$} \\
\hline IAC-24 & $3,78 \mathrm{a}$ & $6,02 \mathrm{a}$ & $19,16 \mathrm{a}$ & $9,65 a$ & ns \\
\hline ITD-19 & $5,49 a$ & $10,15 \mathrm{a}$ & $5,71 \mathrm{~b}$ & $7,12 \mathrm{a}$ & $\begin{array}{l}Y=5,496+0,153 x-0,001 x^{2} \\
r^{2}=0,70\end{array}$ \\
\hline IAC-355 & $8,66 \mathrm{a}$ & $7,73 \mathrm{a}$ & $6,18 b$ & $7,52 \mathrm{a}$ & ns \\
\hline $\begin{array}{l}\text { Regressão } \\
\text { polinomial(2) }\end{array}$ & & & & & ns \\
\hline Dms & 5,14 & 2,97 & & & \\
\hline
\end{tabular}

"Letras iguais não diferem entre si pelo teste de T-student a $5 \%$. As letras são para comparação entre genótipos na vertical. dms: diferença mínima significativa (1) regressão polinomial para doses dentro de cada genótipo, (2) regressão polinomial para doses, independentemente do genótipo. 
Tabela 6. Análise da atividade microbiana por respirometria e $\mathrm{qCO}_{2}$ no solo rizosférico de 3 genótipos de trigo cultivados com 3 doses crescentes de $\mathrm{N}$.

\begin{tabular}{|c|c|c|c|c|c|}
\hline \multirow{2}{*}{$\begin{array}{l}\text { Tratamentos } \\
\text { GENÓTIPOS }\end{array}$} & \multicolumn{3}{|c|}{ Doses de N, Kg.ha ${ }^{-1}$} & \multirow{2}{*}{$\begin{array}{l}\text { Média } \\
\text { doses }\end{array}$} & \multirow[b]{2}{*}{ Regressão polinomial (1) } \\
\hline & 0 & 60 & 120 & & \\
\hline \multicolumn{6}{|c|}{ Respirometria, $\mu \mathrm{g} \mathrm{CO}_{2} \mathrm{~g}^{-1} \mathrm{dia}^{-1}$} \\
\hline IAC-24 & $71,17 \mathrm{a}$ & $81,35 \mathrm{a}$ & $91,89 a$ & $81,47 \mathrm{a}$ & ns \\
\hline ITD-19 & $77,83 \mathrm{a}$ & $80,56 \mathrm{a}$ & $92,22 \mathrm{a}$ & $83,54 \mathrm{a}$ & ns \\
\hline IAC-355 & $84,49 a$ & $81,18 a$ & $88,15 a$ & $84,61 \mathrm{a}$ & ns \\
\hline $\begin{array}{l}\text { Regressão } \\
\text { polinomial(2) }\end{array}$ & & & & & ns \\
\hline Dms & 18,63 & & & 10,76 & \\
\hline \multicolumn{6}{|l|}{$\mathrm{qCO}_{2}$} \\
\hline ITD-19 & $10,83 a b$ & 8,33 a & $12,60 \mathrm{a}$ & $10,59 a b$ & ns \\
\hline IAC-355 & $6,72 \mathrm{~b}$ & $9,12 \mathrm{a}$ & 9,97 a & $8,60 \mathrm{~b}$ & ns \\
\hline $\begin{array}{l}\text { Regressão } \\
\text { polinomial(2) }\end{array}$ & & & & & ns \\
\hline Dms & 6,10 & & & 3,52 & \\
\hline
\end{tabular}

"Letras iguais não diferem entre si pelo teste de T-student a $5 \%$. As letras são para comparação entre genótipos na vertical. dms: diferença mínima significativa (1) regressão polinomial para doses dentro de cada genótipo, (2) regressão polinomial para doses, independentemente do genótipo. 
Tabela 7. Quantificação de microrganismos envolvidos na cilclagem do $\mathrm{N}$ do solo; amonificadores, nitritadores e nitratadores, na raiz de 3 genótipos de trigo cultivados com 3 doses crescentes de $\mathrm{N}$ (média de 3 repetições) $)^{1 /}$.

\begin{tabular}{|c|c|c|c|c|c|}
\hline \multirow{2}{*}{$\begin{array}{l}\text { Tratamentos } \\
\text { GENÓTIPOS }\end{array}$} & \multicolumn{3}{|c|}{ Doses de N, Kg.ha' } & \multirow[b]{2}{*}{$\begin{array}{l}\text { Média } \\
\text { doses }\end{array}$} & \multirow[b]{2}{*}{ Regressão polinomial (1) } \\
\hline & 0 & 60 & 120 & & \\
\hline \multicolumn{6}{|c|}{ Contagem de amonificadores $(\log x+1)$} \\
\hline IAC-24 & $7,14 \mathrm{~b}$ & $7,37 \mathrm{a}$ & $7,59 a$ & 7,37 b & ns \\
\hline ITD-19 & $7,61 \mathrm{a}$ & $6,88 \mathrm{~b}$ & $7,26 \mathrm{~b}$ & $7,25 \mathrm{~b}$ & $\begin{array}{l}Y=7,642-0,021 x+0,0002 x^{2} \\
r^{2}=0,77\end{array}$ \\
\hline IAC-355 & $7,78 \mathrm{a}$ & $7,44 a$ & $7,63 \mathrm{a}$ & $7,62 \mathrm{a}$ & $\begin{array}{l}Y=7,788-0,010 x+0,00007 x^{2} \\
r^{2}=0,75\end{array}$ \\
\hline $\begin{array}{l}\text { Regressão } \\
\text { polinomial(2) }\end{array}$ & & & & & ns \\
\hline Dms & 0,28 & & & 0,16 & \\
\hline \multicolumn{6}{|c|}{ Contagem de amonificadores $\mathrm{n}^{0} 10^{5} \mathrm{~g}^{-1}$ solo } \\
\hline IAC-24 & $18,05 \mathrm{~b}$ & $42,82 \mathrm{a}$ & $61,41 \mathrm{a}$ & & \\
\hline ITD-19 & $26,14 \mathrm{a}$ & $8,09 \mathrm{~b}$ & 28,40 a & & \\
\hline IAC-355 & $40,55 a$ & $20,69 \mathrm{~b}$ & 37,30 a & & \\
\hline \multicolumn{6}{|c|}{ Contagem de nitritadores $(\log x+1)$} \\
\hline IAC-24 & $8,56 \mathrm{a}$ & $9,11 \mathrm{a}$ & $9,67 \mathrm{a}$ & $9,11 \mathrm{a}$ & ns \\
\hline ITD-19 & $8,67 \mathrm{a}$ & 9,09 a & 9,39 a & 9,05 a & ns \\
\hline Dms & 0,92 & & & 0,53 & \\
\hline \multicolumn{6}{|c|}{ Contagem de nitritadores, $\mathrm{n}^{0} \mathrm{~g}^{-1}$ solo } \\
\hline IAC-24 & $508 \mathrm{a}$ & 733 a & $890 \mathrm{a}$ & & \\
\hline ITD-19 & $1783 \mathrm{a}$ & $2250 \mathrm{a}$ & 2283 a & & \\
\hline IAC-355 & $7400 \mathrm{a}$ & $2500 \mathrm{a}$ & $2233 \mathrm{a}$ & & \\
\hline \multicolumn{6}{|c|}{ Contagem de nitratadores $(\log x+1)$} \\
\hline IAC-24 & $3,53 \mathrm{a}$ & $3,49 a$ & $4,63 \mathrm{a}$ & $3,88 \mathrm{a}$ & ns \\
\hline ITD-19 & $3,48 \mathrm{a}$ & $3,70 \mathrm{a}$ & $4,34 \mathrm{a}$ & $3,84 \mathrm{a}$ & ns \\
\hline IAC-355 & $3,50 \mathrm{a}$ & $3,95 \mathrm{a}$ & $4,29 \mathrm{a}$ & $3,91 \mathrm{a}$ & ns \\
\hline $\begin{array}{l}\text { Regressão } \\
\text { polinomial(2) }\end{array}$ & & & & & $Y=3,424+0,008 \times r^{2}=0,55$ \\
\hline Dms & 0,61 & & & 0,35 & \\
\hline \multicolumn{6}{|c|}{ Contagem nitratadores, $\mathrm{n}^{0} \mathrm{~g}^{-1}$ solo } \\
\hline IAC-24 & $496 \mathrm{a}$ & 396 a & $376 \mathrm{a}$ & & \\
\hline ITD-19 & $400 \mathrm{a}$ & $640 \mathrm{a}$ & $1050 \mathrm{a}$ & & \\
\hline IAC-355 & $726 \mathrm{a}$ & $2133 a$ & 1966 a & & \\
\hline
\end{tabular}


Tabela 8. Massa da matéria seca da parte aérea e produção de grãos de 3 genótipos de trigo cultivados com 3 doses crescentes de N. (média de 3 repetições) ${ }^{1 /}$.

\begin{tabular}{|c|c|c|c|c|c|}
\hline \multirow{2}{*}{$\begin{array}{l}\text { Tratamentos } \\
\text { GENÓTIPOS }\end{array}$} & \multicolumn{3}{|c|}{ Doses de N, Kg.ha ${ }^{-1}$} & \multirow[b]{2}{*}{$\begin{array}{l}\text { Média } \\
\text { doses }\end{array}$} & \multirow[b]{2}{*}{ Regressão polinomial (1) } \\
\hline & 0 & 60 & 120 & & \\
\hline \multicolumn{6}{|c|}{ Massa da matéria seca da parte aérea, g mlinear ${ }^{-1}$} \\
\hline IAC-24 & $55,70 \mathrm{a}$ & 100,16 a & $109,72 \mathrm{a}$ & $88,53 \mathrm{a}$ & ns \\
\hline ITD-19 & $61,66 \mathrm{a}$ & $112,38 \mathrm{a}$ & $116,28 \mathrm{a}$ & $96,8 \mathrm{a}$ & ns \\
\hline IAC-355 & $61,72 \mathrm{a}$ & $103,00 \mathrm{a}$ & $110,22 \mathrm{a}$ & 91,65 a & \\
\hline $\begin{array}{l}\text { Regressão } \\
\text { polinomial(2) }\end{array}$ & & & & & $\begin{array}{l}Y=59,694+1,079 x+0,005 x^{2} \\
r^{2}=0,76\end{array}$ \\
\hline Dms & 29,92 & & & 17,27 & \\
\hline \multicolumn{6}{|c|}{ Produtividade, $\mathrm{Kg} \mathrm{ha}^{-1}$} \\
\hline IAC-24 & 1902,33 a & $3259,66 \mathrm{~b}$ & $3610,00 \mathrm{~b}$ & $2924 \mathrm{~b}$ & $\begin{array}{l}Y=1902,3+31,014 x-0,139 x^{2} \\
r^{2}=0.91\end{array}$ \\
\hline ITD-19 & $1389,00 \mathrm{a}$ & $3672,66 a b$ & $4276,33 \mathrm{a}$ & $3113 a b$ & $\begin{array}{l}Y=1389+52,061 x-0,233 x^{2} \\
r^{2}=0,93\end{array}$ \\
\hline IAC-355 & 1971,66 a & 3859,66 a & $4359,66 \mathrm{a}$ & 3397 a & $\begin{array}{l}Y=-1971,7+43,033 x-0,193 x^{2} \\
r^{2}=0,96\end{array}$ \\
\hline $\begin{array}{l}\text { Regressão } \\
\text { polinomial(2) }\end{array}$ & & & & & $\begin{array}{l}Y=1754,3+42,036 x-0,189 x^{2} \\
r^{2}=0,87\end{array}$ \\
\hline Dms & 507,73 & & & 293,14 & \\
\hline
\end{tabular}


Tabela 9. Teor, quantidade acumulada e eficiência de utilização do $\mathrm{N}$ por metro linear de planta de 3 genótipos de trigo cultivados com 3 doses crescentes de $\mathrm{N}$ (média de 3 repetições) ${ }^{1 /}$.

\begin{tabular}{|c|c|c|c|c|c|}
\hline \multirow{2}{*}{$\begin{array}{l}\text { Tratamentos } \\
\text { GENÓTIPOS }\end{array}$} & \multicolumn{3}{|c|}{ Doses de N, Kg.ha ${ }^{-1}$} & \multirow[b]{2}{*}{$\begin{array}{l}\text { Média } \\
\text { doses }\end{array}$} & \multirow[b]{2}{*}{ Regressão polinomial (1) } \\
\hline & 0 & 60 & 120 & & \\
\hline \multicolumn{6}{|l|}{ Teor de $\mathrm{N}, \mathrm{g} \mathrm{kg}^{-1}$} \\
\hline IAC-24 & $14,33 \mathrm{a}$ & $21,33 \mathrm{a}$ & $29,33 \mathrm{a}$ & $21,67 \mathrm{a}$ & ns \\
\hline ITD-19 & $10,33 a$ & $20,66 \mathrm{a}$ & $26,67 \mathrm{a}$ & $19,22 \mathrm{a}$ & $\mathrm{ns}$ \\
\hline IAC-355 & $12,67 a$ & $19,67 \mathrm{a}$ & $35,00 \mathrm{a}$ & $22,44 \mathrm{a}$ & \\
\hline $\begin{array}{l}\text { Regressão } \\
\text { polinomial(2) }\end{array}$ & & & & & $Y=12,167+0,149 \times r^{2}=0,79$ \\
\hline Dms & 6,21 & & & 3,59 & \\
\hline \multicolumn{6}{|c|}{$\mathrm{N}$ acumulado, g m linear ${ }^{-1}$} \\
\hline IAC-24 & $0,79 a$ & $2,14 \mathrm{a}$ & $3,24 \mathrm{a}$ & $2,06 \mathrm{a}$ & ns \\
\hline ITD-19 & $0,64 \mathrm{a}$ & $2,35 \mathrm{a}$ & $3,07 \mathrm{a}$ & $1,87 \mathrm{a}$ & ns \\
\hline IAC-355 & $0,72 \mathrm{a}$ & $2,02 \mathrm{a}$ & $4,30 \mathrm{a}$ & $2,35 a$ & \\
\hline $\begin{array}{l}\text { Regressão } \\
\text { polinomial(2) }\end{array}$ & & & & & $Y=0,691+0,023 \times r^{2}=0,82$ \\
\hline Dms & 0,70 & & & 0,41 & \\
\hline \multicolumn{6}{|c|}{ IEU do $N, g^{2} g$ m linear ${ }^{-1}$} \\
\hline IAC-24 & $3935 \mathrm{~b}$ & $4686 a$ & $3945 a$ & $4189 \mathrm{~b}$ & ns \\
\hline ITD-19 & $5960 \mathrm{a}$ & $5421 \mathrm{a}$ & $4432 \mathrm{a}$ & $5272 a$ & ns \\
\hline IAC-355 & $4548 a b$ & $5264 \mathrm{a}$ & $3480 \mathrm{a}$ & $4431 b$ & ns \\
\hline $\begin{array}{l}\text { Regressão } \\
\text { polinomial(2) }\end{array}$ & & & & & $\begin{array}{l}Y=4814,9+17,492 x-0,206 x^{2} \\
r^{2}=0,26\end{array}$ \\
\hline Dms & 1558 & & & 899 & \\
\hline
\end{tabular}


Tabela 10. Teor, quantidade acumulada e eficiência de utilização do $\mathrm{P}$ por metro linear de planta de 3 genótipos de trigo cultivados com 3 doses crescentes de $\mathrm{N}$ (média de 3 repetições) ${ }^{1 /}$.

\begin{tabular}{|c|c|c|c|c|c|}
\hline \multirow{2}{*}{$\begin{array}{l}\text { Tratamentos } \\
\text { GENÓTIPOS }\end{array}$} & \multicolumn{3}{|c|}{ Doses de N, Kg.ha ${ }^{-1}$} & \multirow[b]{2}{*}{$\begin{array}{l}\text { Média } \\
\text { doses }\end{array}$} & \multirow[b]{2}{*}{ Regressão polinomial (1) } \\
\hline & 0 & 60 & 120 & & \\
\hline \multicolumn{6}{|l|}{ Teor de $\mathrm{P}, \mathrm{g} \mathrm{kg}^{-1}$} \\
\hline IAC-24 & $2,23 a$ & $2,93 \mathrm{a}$ & $3,23 a$ & $2,80 a$ & ns \\
\hline ITD-19 & $2,23 a$ & $3,17 \mathrm{a}$ & $3,30 \mathrm{a}$ & $2,93 \mathrm{a}$ & ns \\
\hline IAC-355 & $2,60 \mathrm{a}$ & $3,03 \mathrm{a}$ & $3,17 \mathrm{a}$ & $2,93 \mathrm{a}$ & ns \\
\hline $\begin{array}{l}\text { Regressão } \\
\text { polinomial(2) }\end{array}$ & & & & & $\begin{array}{l}Y=2,389+0,015 x- \\
0,00006 x^{2} r^{2}=0,72\end{array}$ \\
\hline Dms & 0,44 & & & 0,25 & \\
\hline \multicolumn{6}{|c|}{$\mathrm{P}$ acumulado, $\mathrm{g}$ m linear ${ }^{-1}$} \\
\hline IAC-24 & $0,12 \mathrm{a}$ & $0,29 a$ & $0,35 \mathrm{a}$ & $0,26 \mathrm{a}$ & ns \\
\hline ITD-19 & $0,14 a$ & $0,36 \mathrm{a}$ & $0,38 a$ & $0,29 a$ & ns \\
\hline IAC-355 & $0,15 a$ & $0,31 \mathrm{a}$ & $0,39 a$ & $0,28 \mathrm{a}$ & \\
\hline $\begin{array}{l}\text { Regressão } \\
\text { polinomial(2) }\end{array}$ & & & & & $\begin{array}{l}Y=0,138+0,004 x- \\
0,00002 x^{2} r^{2}=0,82\end{array}$ \\
\hline Dms & 0,10 & & & 0,06 & \\
\hline \multicolumn{6}{|c|}{ IEU do $P, g^{2} g$ m linear ${ }^{-1}$} \\
\hline IAC-24 & 24987 a & $34197 \mathrm{a}$ & $34120 \mathrm{a}$ & $31102 \mathrm{a}$ & ns \\
\hline ITD-19 & $26451 \mathrm{a}$ & $35258 \mathrm{a}$ & $35597 a$ & 32436 a & ns \\
\hline IAC-355 & $22777 \mathrm{a}$ & 34038 a & 38475 a & $31763 \mathrm{a}$ & \\
\hline $\begin{array}{l}\text { Regressão } \\
\text { polinomial(2) }\end{array}$ & & & & & $\begin{array}{l}Y=24739+230,94 x- \\
1,138 x^{2} r^{2}=0,59\end{array}$ \\
\hline Dms & 8414 & & & 4858 & \\
\hline
\end{tabular}

Tabela 11. Teor de $\mathrm{N}$ no grão de 3 genótipos de trigo cultivados com 3 doses crescentes de $\mathrm{N}$ (média de 3 repetições) ${ }^{1 /}$.

\begin{tabular}{|c|c|c|c|c|c|}
\hline \multirow{2}{*}{$\begin{array}{l}\text { Tratamentos } \\
\text { GENÓTIPOS }\end{array}$} & \multicolumn{3}{|c|}{ Doses de N, Kg.ha ${ }^{-1}$} & \multirow[b]{2}{*}{$\begin{array}{l}\text { Média } \\
\text { doses }\end{array}$} & \multirow[b]{2}{*}{ Regressão polinomial (1 } \\
\hline & 0 & 60 & 120 & & \\
\hline \multicolumn{6}{|c|}{ Teor de N no grão, $\mathrm{g} \mathrm{kg}^{-1}$} \\
\hline IAC-24 & $38,53 \mathrm{~A}$ & $39,53 \mathrm{~A}$ & $44,80 \mathrm{~A}$ & $40,95 \mathrm{~A}$ & ns \\
\hline ITD-19 & $34,27 \mathrm{~A}$ & $43,60 \mathrm{~A}$ & $48,43 \mathrm{~A}$ & $42,10 \mathrm{~A}$ & ns \\
\hline IAC-355 & $39,23 \mathrm{~A}$ & $43,87 \mathrm{~A}$ & $49,90 \mathrm{~A}$ & $44,33 \mathrm{~A}$ & ns \\
\hline $\begin{array}{l}\text { Regressão } \\
\text { polinomial(2) }\end{array}$ & & & & & $\begin{array}{l}Y=0,086 x+37,28 \\
R^{2}=0.59\end{array}$ \\
\hline Dms & 6,25 & & & 4,30 & \\
\hline
\end{tabular}

"Letras iguais não diferem entre si pelo teste de T-student a $5 \%$. As letras são para comparação entre genótipos na vertical. dms: diferença mínima significativa (1) regressão polinomial para doses dentro de cada genótipo, (2) regressão polinomial para doses, independentemente do genótipo. 
Tabela 12. Coeficientes de correlação de Pearson a 5\% de probabilidade.

\begin{tabular}{llll}
\hline & Colonização & Microrganismos & Microrganismos \\
micorrízica & nitrificadores & nitratadores \\
\hline Teor de N & $\mathrm{r}=0,68$ & $\mathrm{r}=0,61$ & $\mathrm{r}=0,71$ \\
Qa de N & $\mathrm{r}=0,70$ & $\mathrm{r}=0,63$ & $\mathrm{r}=0,74$ \\
Teor de P & $\mathrm{r}=0,50$ & $\mathrm{~ns}$ & $\mathrm{~ns}$ \\
Qa de P & $\mathrm{r}=0,60$ & $\mathrm{~ns}$ & $\mathrm{~ns}$ \\
IEU de P & $\mathrm{r}=0,60$ & $\mathrm{~ns}$ & $\mathrm{~ns}$ \\
Massa da matéria seca & $\mathrm{r}=0,60$ & $\mathrm{r}=0,44$ & $\mathrm{r}=0,48$ \\
Produtividade & $\mathrm{r}=0,74$ & $\mathrm{r}=0,59$ & $\mathrm{r}=0,61$ \\
\hline
\end{tabular}




\section{REFERÊNCIAS BIBLIOGRÁFICAS}

ANDERSON, T.H.; DOMSCH, K.H. A physiological method for the quantitative measurement of microbial biomass in soil. Soil Biology and Biochemistry, v.10, p.215-221, 1978.

AZCON, R.; OCAMP, J.A. Factors affecting the vesicular-arbuscular infection and mycorrhizal dependency of thirteen wheat cultivars. New Phytologist., v.87, p.677-685, 1981.

BALDANI, V.L.D.; BALDANI, J.I.; DOBEREINER, J. Effects of Azospirillum inoculation on root infection and nitrogen incorporation in wheat. Canadian Journal of Microbiology, v.29, p.924-929, 1983.

BALDANI, V.L.D.; ALVAREZ, M.A.B.; BALDANI; J.I.; DOBEREINER, J. Establishment of inoculated Azospirillum spp. in the rhizosphere and roots of field grown wheat and sorghum. Plant and Soil, v.90, p. 35-46, 1986.

BALDANI, J.I.; CARUSO, L.; BALDANI, V.L.D.; GOI, R.S.; DOBEREINER, J. Recent advances in BNF with non legumes plants. Soil Biology and Biochemistry, v.29, p.922-928, 1997.

BALDANI, V.L.D.; DOBEREINER, J. Host-plant especificity in infection of cereal with Azospirillum spp. Soil Biology and Biochemistry, v.12, p.433-440, 1980. 
BALDANI, J.I.; BALDANI, V.L.D.; DOBEREINER, J. Inoculation of rice plants with the endophytic diazotrophs Herbaspirillum seropedicae and Bulkholderia spp. Biology and Fertility of Soils, v.30, p.485-491, 2000.

BALOTA, E.L.; LOPES, E.S.; HUNGRIA, M.; DOBEREINER, J. Inoculação de bactérias diazotróficas e fungos micorrízico-arbusculares na cultura da mandioca. Pesquisa Agropecuária Brasileira, v.6, p.627-639, 1997.

BARRAQUIO, W.L.; LADHA, J.K.; REVILLA, L. Isolation of endophytic diazotrophic bacteria from wetland rice. Plant and Soil, v.194, p.15-24, 1997.

BASHAN, Y.; LEVANONY, H. Current status of Azospirillum inoculation technology: Azospirillum as a challenge for agriculture. Canadian Journal of Microbiology, v.36, p.591-605, 1990.

BATAGLIA, O.C.; TEIXEIRA, J.P.F.; FURLANI, A.M.C. E GALLO, J.R. Métodos de análise química em plantas. Campinas: Instituto Agronômico de Campinas, 1978. 31p.

BHATTARAI, T.; HESS, D. Growth and yield responses of a Nepalese spring wheat cultivar to the inoculation with Nepalese Azospirillum spp at various levels of N fertilization. Biology and Fertility of Soils, v.26, p.72-77, 1998.

BIRÓ, B.; KOVES-PECHY, K.; VORS, I.; TAKACS, T.; EGGENBERG, P.; STRASSER, R.J. Interrelations between Azospirillum and Rizobium nitrogen fixers and arbuscular mycorrhizal fungi in the rhizosfere of alfafa in sterile, AMF-free or normal soil conditions. Applied Soil Ecology, v.15, p.159-168, 2000. 
BLANKNAU, K.; OLFS, H.W.; KUHLMANN, H. Effect of microbial nitrogen immobilization during the grown period on the availability of nitrogen fertilizer for winter cereals. Biology and Fertility of Soils, v.32, p.157-165, 2000.

BODDEY, R.M.; DOBEREINER, J. Nitrogen fixation associated with grasses and cereals: recent results and perspectives for the future research. Plant and Soil, v.108, p.53-65, 1988.

BODDEY, R.M.; OLIVEIRA, O.C.; URQUAIA, S.; OLIVARES, F.L.; BALDANI, V.L.D.; DOBEREINER, J. Biological nitrogen fixation associated with sugar cane and rice: Contribuitions and prospects for improvement. Plant and Soil, v.174, p.195-209, 1995.

BODDEY, R.M.; URQUAIA, S.; REIS, V.; DOBEREINER, J. Biological nitrogen fixation associated with sugar cane. Plant and Soil, v.137, p.111-117, 1991.

BOTTINI, R.; FULCHIERI, M.; PEARCE, D.; PHARIS, R.P. Identification of giberelins $A_{1}, A_{3}$ in culture of Azospirillum lipoferum. Plant Physiology, v.90, p.45-47, 1989.

BREMNER, J.M. Total nitrogen. In: BLACK, C.A. (Ed.) Methods of soil analisys. Madison: American Society of Agronomy, 1965. p.1149-1178.

BROOKES, P.C.; LANDMAN, A.; PRUDEN, G.; JENKINSON, D.S. Cloroform fumigation and the release of soil nitrogen. Soil Biology and Biochemistry, v.17, p.837-847, 1985.

CATTELAN, J.M.; VIDOR, C. Sistemas de cultura e a população microbiana do solo. Revista Brasileira de Ciência do Solo, v.14, p.125-132,1990. 
CAVALCANT, V.A.; DOBEREINER, J. A new acid-tolerant nitrogen fixing bacterium associeted with sugar cane. Plant and Soil, v.108, p.23-31, 1988.

CLARK, R.B.; ZETO, S.K.; ZOBEL. Arbuscular mycorrhizal fungal isolate effectiveness on grown and root colonization of Panicum virgatum in acidic soil. Soil Biology and Biochemistry, v.31, p.1757-1763, 1999.

COJHO, E.M.; REIS, V.M.; SCHENBERG, A.C.G.; DOBEREINER, J. Interations of $A$. diazotrophicus with amylolytic yeast in nitrogen-free batch culture. FEMS Microbiology, v.108, p.341-346, 1993.

CROSSMAN, S.M.; HILL, W. Inoculation of sweet potato with Azospirillum. Horticultural science, v.22, p.420-422, 1987.

CRUZ, L.M., TEIXEIRA, K.R.S.; BALDANI, J.I. Expressão fenotípica de estirpes de $A$. diazotrophicus contendo o gene nifA de Azotobacter vinelandii. In: REUNIÃO ANUAL DE GENÉTICA DE MICRORGANISMOS, 20., Piracicaba, 1995. Resumos. São Paulo: Sociedade Brasileira de Genética, 1995. p.116.

DIDONET, D.A.; RODRIGUES, O.; KENNER, M.H. Acúmulo de nitrogênio e de massa seca em plantas de trigo inoculadas com Azospirillum brasilense. Pesquisa Agropecuária Brasileira, v.31, n.9, p.645-651, 1996.

DOBEREINER, J.; DAY, J.M. Associative symbiosis in tropical grasses: Caracterization of microrganism and nitrogen- fixing sites. In: INTERNATIONAL SYMPOSIUM ON NITROGEN FIXATION, 1., Washington, 1976. Proceedings. Washington: Washington State University, 1976. p.518538. 
DOBEREINER, J. ; DUQUE, F.F. Contribuição da pesquisa em FBN para o desenvolvimento do Brasil. Revista de Economia Rural, v.18, p.447-460, 1980.

DOBEREINER, J.; BALDANI, J.I.; BALDANI, V.L.D. Como isolar e identificar bactérias diazotróficas de plantas não leguminosas. Brasília: EMBRAPA, SPI.; Itaguaí: EMBRAPA, CNPAB, 1995. 60p.

DOBEREINER, J.; MARRIEL, I.E.; NERY, M. Ecological distribuition of Azospirillum. Canadian Journal of Microbiology, v.22, p.1464-1473, 1976.

DOBBELAERE, S.; CROONENBORGHS, A.; THYS, A.; BROEK, A. V., VANDERLEYDEN. Phytostimulatory effect of Azospirillum brasilense wild type and mutant strains altered in IAA production on wheat. Plant and Soil, v.212, p.155-164, 1999.

DORAN, J.W.; SAFLEY, M. Defining and assessing soil health sustainable productivity. In: PANKHURST, C.; DOUBE, B.M.; GUPTA, V.V.S.R. (Ed) Biological indicators of soil health. Wallingford: CAB International, 1997. p.1-28.

FRANZLUEBBERS, A.J.; HONS, F.M.; ZUBERER, D.A. Soil organic carbon, microbial biomass, and mineralizable carbon and nitrogen in shorgum. Soil Society of America Journal, v.59, p.460-466, 1995

FREITAS, J.G.; CAMARGO, C.E.O.; FERREIRA, A.W.P.F.; CASTRO, J.L. Eficiência e resposta de genótipos de trigo ao nitrogênio. Revista Brasileira de Ciência do Solo,v.19, p.229-234, 1995. 
FURLANI, P.R.; FURLANI, A.M.C. Composição e pH das soluções nutritivas para estudos fisiológicos e seleção de plantas em condições nutricionais adversas. Campinas: IAC, 1988. 34p. (IAC. Boletim Técnico, 78)

GERDEMANN, J.W.; NICOLSON, T.H. Spores of mycorrhizal endogone species extracted from soil by wet sieving and decanting. Transactions of the British Mycological Society, v.6, p.235-246, 1963.

GIOVANNET, M.; MOSSE, B. An evaluation of techniques for measuring vesicular arbuscular mycorrhizal infection in roots. New Pytologist, v.84, p.489-500, 1980.

GOH, T.B.; BANERGLE, M.R.; BURTON, D.L. Vesicular arbuscular mycorrhizae-mediated uptake and translocation of $\mathrm{P}$ and $\mathrm{Zn}$ by wheat in calcareous soil. Canadian Journal of Plant Science, v.77; p.339-346, 1997.

GRAHAM, J.H.; ABBOTT, L.K. Wheat responses to aggressive and non aggressive arbuscular mycorrhizal fungi. Plant and Soil, v.220, p.207-218, 2000.

GRAHAM, P.H.; VANCE C.P. Nitrogen fixation in perspective: an overview of research and extension needs. Field Crops Research, v.65, p.93-106, 2000 .

HETRICK, B.A.D.; WILSON, G.W.T.; COX, T.S. Mycorrhizal dependence of modern wheat varieties and ancestors: a synthesis. Canadian Journal of Botanic, v.71, p.512-518, 1993. 
HOAGLAND, D.R.; ARNON, D.I. The water-culture method for growning plants without soil. Irvine: University of California, 1950. 347p.

HOLL, F.B. Plant Genetics: Manipulation of the host. Canadian Journal of Microbiology, v.29, p.945-953, 1983.

INSAN, H.; MITCHELL, C.C.; DORMAAR, J.F. Relationship of soil microbial biomass and activity with fertilization pratice and crop yield of three ultisoils. Soil Biology and Biochemistry, v.23, p.459-464, 1991.

ISOPI, R.; FABRI, P.; DELGALLO, M.; PUPPI, G. Dual inoculation of sorghum bicolor (L.) Moebch ssp. bicolor with VAM and A. diazotrophicus. Symbiosis, v.18, p.43-55, 1995.

JAMES, E.K. Nitrogen fixation in endophytic and associative symbiosis. Field Crops Research, v.65, p.197-209, 2000.

JIMENEZ-SALGADO, T.; FUENTES-RAMIREZ, L.E.; MARTINEZ-ROMERO; CABALLERO-MELLADO, J. Coffea arabica, a new host plant for $A$. diazotrophicus and isolation of others nitrogen fixing acetobacteria. Applied Environmental Microbiology, v.63, p.3676-3683, 1997.

JOERGENSEN, R.G.; MEYER, B.; MULLER, T. Time-course of the soil microbial biomass under wheat: a one year field study. Soil Biology and Biochemistry, v.26, p.987-994, 1994.

KHAMMAS, K.M.; AGERON, G.; GRIMONT, P.A.; KEISER, P. Azospirillum irakense sp. nov., a nitrogen fixing bacteria associated with rice and rhizosphera soil. Research Microbiology, v.140, p.679-693, 1989. 
KIRCHHOF, G.; REIS, V.M.; BALDANI, J.I., ECKERT, B.; DÖBEREINER, J.; HARTMANN, A. Occurrence, physiological and molecular analysis of endophytic diazotrophic bacteria in gramineous energy plants. Plant and Soil, v.194, p.45-55, 1997.

LOVELL, R. D.; HATCH, D.J. Stimulation of microbial activity following spring applications of nitrogen. Biology and Fertility of Soils, v.26, p.28-30, 1998.

LYNCH, J.M.; WHIPPS, J. M. Substrate flow in the rhizosphere. Plant and Soil, v.129, p.1-10, 1990.

LUPWAYI, N.Z.; RICE, W.A.; CLAYTON, G.W. Soil microbial diversity and community structure under wheat as influenced by tillage and crop rotation. Soil Biology and Biochemistry, v.30, p.1733-1741, 1998.

MAGALHÃES, F.M.; BALDANI, J.I.; SOUTO, S.M.; KUYKENDALL, J.R.; DOBEREINER, J. A new acid tolerant Azospirillum species. Anais da Academia Brasileira de Ciência, v.55, p.417-430,1983.

MANSKE, G.G.B.; LÜTTGER, A.B.; BEHL, R.K.; VLEK, P.L.G. Nutrient efficiency based on VA mycorrhizae and total root lenght of wheat cultivars grown in India. Angewandte Botanic, v.69, p.108-110, 1995.

MARSCHENER, $\mathrm{H}$. Role of root growth, arbuscular mycorrhiza, and root exudates for the efficiency in nutrient acquisition. Field Crops Research, v.56, p.203-207, 1998. 
MARTIN, P.; GLATZLE, A.; KOLB, W.; OMAY, H.; SCHMIDT, W. N N $_{2}$ fixing bacteria in the rizosphere: quantification and hormonal effects on root development. Zeitschrift Pflanzenernährung Bodenkunde, v.152, p.237245, 1989.

MENGEL, K. Turnover of organic nitrogen in soil and its availability to crops. Plant and Soil, v.181, p.83-93, 1996.

MILLET, E.; FELDMAN, M. Yield response of common spring wheat cultivar to inoculation with Azospirillum brasilense at various levels of nitrogen fertilization. Plant and Soil, v.80, p.255-259, 1984.

MOSSE, B. The establishment of vesicular-arbuscular mycorrhizae under aseptic conditions. Journal of General Microbiology, v.27, p.509-520, 1962.

MUTHUKUMANASAMY, R.; REVATHI, G.; LAKSHMINARASIMAHAN. Influence of $\mathrm{N}$ fertilazation on the isolation of Acetobacter diazotrophicus and Herbaspirillum spp. From Indian sugar cane varieties. Biology and Fertility of Soil, v.29, p.157-164, 1999.

NUERNBERG, N.J.; VIDOR, C.; STAMMEL, J.G. Efeito de sucessões de culturas e tipos de adubação na densidade populacional e atividade microbiana do solo. Revista Brasileira de Ciência do Solo, v.8, p.197-203, 1984.

OKON, Y. Azospirillum as a potencial inoculant for agriculture. Trends in Biotechnology, v.3, p.223-228, 1985. 
OLIVARES, F.L.; BALDANI, J.I.; JAMES, E.K.; DOBEREINER, J. Infection of mottled stripe disease and resistant sugar varieties by endophitic diastrophic Herbaspirillum. New Phytologist, v.135, p.723-737, 1997.

OLIVEIRA, O.C.; URQUIAGA, S.; BODDEY, R.M. Burning cane: the long term effects. International Sugar Journal, v.96, p.272-275, 1994.

PACOVSKY, R.S.; FULLER, G. Influence of soil on interactions between endomycorrhizae and Azospirillum in sorghum. Soil Biology and Biochemistry, v.4, p.525-531, 1985.

PACOVSKY, R.S. Metabolic differences in Zea-Glomus-Azospirillum symbiosis. Soil Biology and Biochemistry, v.21, p.953-960, 1989.

PAULA, M.A.; REIS, V.M.; URQUAIA, S.; DOBEREINER, J. Interação sorgomicorriza vesiciular-arbuscular-bactérias diazotróficas. In: REUNIÃO BRASILEIRA DE FERTILIDADE DO SOLO E NUTRIÇÃO DE PLANTAS, 19., Santa Maria, 1990. Resumos. Santa Maria: Sociedade Brasileira de Ciência do Solo, 1990. p.24.

PAULA, M.A.; REIS, V.M.; DOBEREINER, J. Interations of Glomus clarum with A.dizotrophicus in infection of sweet potato, sugar cane, sweet shorgum. Biology and Fertility of Soils, v.11, p.111-115, 1991.

PAULA, M.A.; URQUAIA, S.; SIQUEIRA, J.O.; DOBEREINER, J. Synergistic effects of vesicul;ar-arbuscular mycorrhizal fungi and diazotrophic bactéria on nutrition and grown of sweet potato. Biology and Fertility of Soils, v.14, p.61-66, 1992. 
PAULA, M.A.; SIQUEIRA, J.O.; DOBEREINER, J. Ocorrência de fungos micorrízicos vesiculo arbusculares e de bactérias diazotróficas na cultura da batata-doce. Revista Brasileira de Ciência do Solo, v.17, p.349-356, 1993.

PEOPLES, M.B.; HERRIDGE, D.F.; LADHA, J.K. Biological nitrogen fixation: An efficient source of nitrogen for sustainable agricultural production. Plant and Soils, v.174, p.23-28, 1995.

PHILLIPS, P.S.; HAYMAN, D.S. Improved procedures for clearing roots and staining parasitic and vesicular arbuscular mycorrhizal fungi for rapid assessment of infection. Transactions of the British Mycologycal Society, v.55, p.158-161, 1970.

PIRT, S.J. Principles of microbe and cell cultivation. Oxford: Blackwell Scientific, 1975. 274p.

PRAMER, D.; SCHMIDT, E.L. Experimental soil microbiology. Minneapolis: Burgess publishing company, 1964. 120p.

RAIJ, B.van; CANTARELLA, H.; QUAGGIO, J.A.; FURLANI, A.M.C. Recomendações de adubação e calagem para o Estado de São Paulo. Campinas: IAC, 1997, 285p. (IAC. Boletim 100)

REINHOULD, B.; HURCK, T.; FENDRICK, I.; GILLIS, M.; DELEY, J. Azospirillum halopraeferans nov. a nitrogen fixing organism associated with roots of Kallar grasses. International Journal of Systematics Bacteriology, v.37, p.43-51, 1987. 
REIS, V.M.; PAULA, M.A.; DOBEREINER, J. Ocorrência de micorrizas arbusculares e da bactéria diazotrófica Acetobacter diazotrophicus em canade-açúcar. Pesquisa Agropecuária Brasileira, v.10, p.1933-1941, 1999.

REIS, V.M.; BALDANI, J.I.; BALDANI, V. L.; DOBEREINER, J. Biological dinitrogen fixation in gramineae and palm trees. Critical Reviews in Plant Science, v.19, n.3, p.227-247, 2000.

REIS, V.M.; OLIVARES; F.L.; DOBEREINER, J. Improved methodology for isolation of diazotrophicus and confirmation of its endophytic habitat. World Journal of Microbiology and Biothecnology, v.10, p.23-31, 1994.

REYNDERS, L.; VLASSAK, K. Use of Azospirillum brasilense as biofertilizer in intensive wheat cropping. Plant and Soil, v.66, p.217-273, 1982.

RODRIGUES, O.; DIDONET, D.A; GOUVEIA, J.A.; SOARES, R.C. Translocação de nitrogênio em trigo infectado por Azospirillum e adubado com nitrogênio. Pesquisa Agropecuária Brasileira, v.35, n.7, p.1473-1481, 2000.

SALOMONE, I.G.; DÖBEREINER, J. Maize genotype effects on the response to Azospirillum inoculation. Biology and Fertility of Soils, v.21, p.193-196, 1996.

SARATCHANDRA, S.V. Nitrification activities and changes in the population of nitrifying bacteria in soil perfused with two different $\mathrm{H}$-ion concentration. Plant and Soil, v.50, p.99-111, 1978. 
SCHOLOTER, M.; HARTMANN, A. Endophytic and surface colonization of wheat roots (triticum aestivum) by different Azospirillum brasilense strains studied with strain-specific monoclonal antibodies. Symbiosis, v.25, p.159-179, 1998.

SPARLING, G.P. Ratio of microbial biomass carbon to soil organic carbon as a sensitive indicator of changes in soil organic matter. Australian Journal of Soil Research, v.30, p.195-207, 1992.

SPARLING, G.P. Soil microbial biomass, activity and nutrient cycling as indicators of soil health. In: PANKHURST, C.; DOUBE, B.M.; GUPTA, V.V.S.R. (Ed) Biological indicators of soil health. Wallingford: $C A B$ International, 1997. p.97-119.

SILVA, G.; VIDOR, C. As práticas de manejo de solo na população microbiana. Revista Brasileira de Ciência do Solo, v.8, p.291-296, 1984.

STEENHOUDT, O.; VANDERLEYDEN, J. Azospirillum, a free-living nitrogenfixing bacterium closely associated with grasses: genetic, biochemical and ecological aspects. FEMS Microbiology Reviews, v.24, p.487-506, 2000.

STOLTZFUS, J. R.; SO, R.; MALARVITHI, P.P.; LADHA, K.K.; BRUIJN, F.J. Isolation of endophytic bacteria from rice and assessment of their potential for supplying rice with biologically fixed nitrogen. Plant and Soil, v.194, p.2536, 1997.

THIRUKKUMARAN, C.M.; PARKINSON, D. Microbial respiration, biomass, metabolic quotient and litter decomposition in a lodgepole pine forest floor amended with nitrogen and phosphorous fertilizers. Soil Biology and Biochemistry, v.32, p.59-66, 2000. 
TILAK, K.V.B.R.; LI, C.Y.; HO, I. Ocurrence of nitrogen fixing Azospirillum in vesicular-arbuscular mycorrhizal fungi. Planta and Soil, v.116, p. 286-288, 1989.

VANCE, E.D.; BROOKES, P.C; JENKINSON, D.S. An extraction method for measuring soil microbial biomass C. Soil Biology and Biochemistry, v.19, p.703-707, 1987.

VARMA, A.K.; SINGH, K.; LALL, V.K. Lumen bacteria from endomycorrhizal spores. Current Microbiology, v.6, p.207-211, 1981.

VÁZQUEZ, M.M.; BAREA, J.M.; AZCÓN, R. Impact of soil nitrogen concentration on Glomus spp.-Sinorhizobium interactions as affecting growth, nitrate reductase activity and protein content of Medicago sativa. Biology and Fertility of Soil, v.34, p.57-63, 2001.

VÁZQUEZ, M.M.; CÉSAR, S.; AZCÓN, R.; BAREA, J.M. Interractions between arbuscular mycorrhizal fungi and other microbial inoculants (Azospirillum, Pseudomonas, Trichoderma) and their effects on microbial population and enzyme activities in the rizosphere of maize plants. Applied Soil Ecology, v. 15, p.261-272, 2000.

WALKLEY, A. A critical examination of a rapid method for determining organic carbon in soils-effect of variations in digestion conditions and of inorganic soil constituents. Soil Science, v.63, p.251-264, 1947.

WHITMORE, A.P. Alternative kinetic laws to descriptive the turnover of the microbial biomass. Plant and Soil, v.181, p.169-173, 1996. 
YANNI, Y.G.; RIZK, R.Y.; CORICH, V.; SQUARTINI, A.; NINKE, K.; PHILIPHOLLINGSWORTH, S.; ORGAMBIDE, G.; BRUIJN, F.D.; STOLTZFUS, J.; BUCKLEY, D.; SCHMIDT, T.M.; MATEOS, P.F.; LADHA, J.K.; DAZZO, F.B. Natural endophytic associations between Rhizobium leguminosarum bv. Trifolii and rice roots and assessment of its potential to promote rice growth. Plant and Soil, v.194, p.99-114, 1997. 